\title{
Biostratigraphy of the Lower Cretaceous Schrambach Formation on the classical locality of Schrambachgraben (Northern Calcareous Alps, Salzburg Area)
}

\author{
DANIELA BOOROVÁ, PETR SKUPIEN, ZdENĚK VAŠíČEK \& HARALD LOBITZER
}

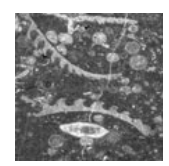

\begin{abstract}
Schrambach Formation in the Eastern Alps area is conceived from the lithological and stratigraphical point of view rather non-uniform. Therefore a $200 \mathrm{~m}$ thick section in the type locality of the Schrambach Formation, situated south of Salzburg, is documented in this study. The studied sequence in the Schrambachgraben seems to be in the prevailing part of section in simple, monoclinal mode of deposition. The opposite is true. The section studied begins with the Oberalm Formation, passes gradually into the Schrambach Formation and ends with the lower part of the Rossfeld Formation. According to our detail results, deposits of the Schrambach Formation in this type of section occur in a minimum of three tectonic slices. The first tectonic slice is composed of a transitional sequence of the Oberalm Formation to the Schrambach Formation. The uppermost part of the Oberalm Formation is dated as the Middle Berriasian Calpionella Zone (Elliptica Subzone). According to calcareous dinoflagellates, the lower part of the stratal sequence of the Schrambach Formation belongs to the Fusca Acme Zone, which corresponds to the early part of the Late Berriasian. According to the occurrence of the calpionellids Calpionellites uncinata, Cts. darderi and Cts. major, the second slice belongs to the Early Valanginian. With respect to occurrences of ammonites and non-calcareous dinoflagellates findings, the tectonic slice belongs to the higher Late Berriasian Subthurmannia boissieri ammonite Zone. The Early Valanginian age of the uppermost accessible part of the section is indicated by sporadic findings of Calpionellites darderi and Cts. major and ammonite Thurmanniceras pertransiens. A new genus, Schrambachoceras gen. nov., and a new species, Schrambachoceras weidichi sp. nov., were identified. The basal part of the Rossfeld Formation contains ammonites and non-calcareous dinoflagellates of Late Valanginian age (Neocomites peregrinus ammonite Zone). - Key words: biostratigraphy, calpionellids, calcareous and non-calcareous dinoflagellata, ammonites, Oberalm, Schrambach and Rossfeld formations, Berriasian, Valanginian.
\end{abstract}

BoOROVÁ, D., SKUPIEN, P., VAŠíčEK, Z. \& LOBITZER, H. 2015. Biostratigraphy of the Lower Cretaceous Schrambach Formation on the classical locality of Schrambachgraben (Northern Calcareous Alps, Salzburg Area). Bulletin of Geosciences 90(1), 89-131 (10 figures, 1 table, appendix). Czech Geological Survey, Prague. ISSN 1214-1119. Manuscript received August 26, 2013; accepted in revised form September 12, 2014; published online December 12, 2014; issued January 26, 2015.

Daniela Boorová, State Geological Institute of Dionýz Štúr, Mlynská dolina 1, SK 81704 Bratislava, Slovak Republic; daniela.boorova@geology.sk • Petr Skupien, Institute of Geological Ingeneering, VŠB - Technical University of Ostrava, 17. listopadu 15,CZ70833 Ostrava-Poruba, Czech Republic; petr.skupien@vsb.cz•Zdeněk Vašíček, Institute of Geonics, Academy of Sciences of the Czech Republic, Studentská 1768, CZ 70800 Ostrava-Poruba, Czech Republic; zdenek.vasicek@ugn.cas.cz・Harald Lobitzer, Lindaustraße 3, A 4820 Bad Ischl, Austria

In the years 2000-2001 we studied and documented Lower Cretaceous sequence in the type locality of the Schrambach Formation situated in the area of Schrambachgraben in the area of Salzburg. The first results of this study (Rasser et al. 2003) we focused also on an overview of previous studies into the Schrambachschichten and on the hitherto concept of the Schrambach Formation.

In addition, the type locality of the Schrambachschichten, its stratigraphy and lithostratigraphy, geological and depositional conditions, macro- and micropaleontology with microfacies are described in detail here, along with designation of sampling points for thin sections and microanalyses.

The goal of the study submitted is primarily to provide detailed biostratigraphy of the Schrambach Formation in the type locality. Our microbiostratigraphic research focuses on the study of calpionellids and calcareous and non-calcareous dinoflagellates. Ammonites and aptychi, 


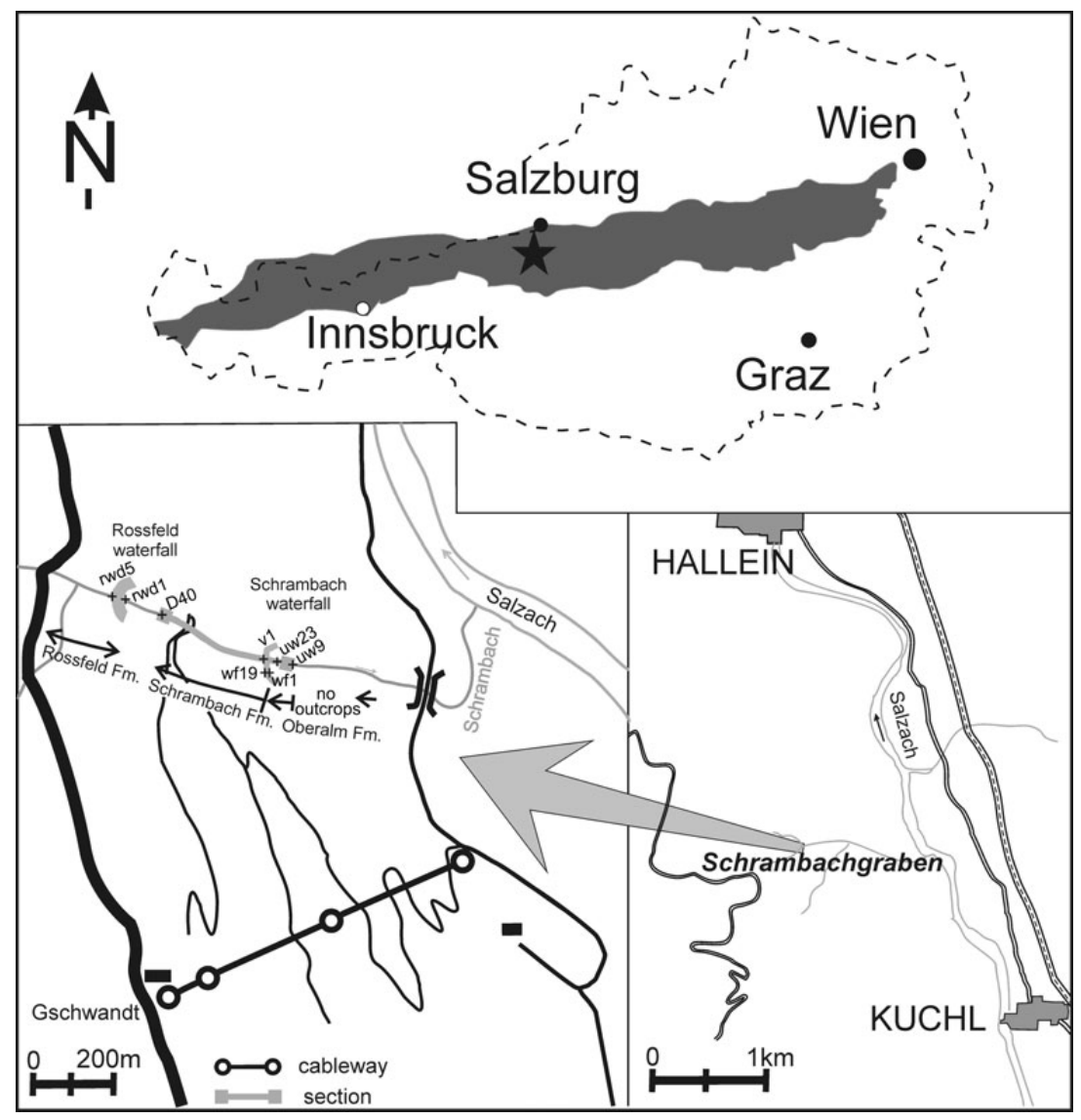

Figure 1. Topographic situation of the studied locality.

we have found in the Schrambach Fm. and in basal part of the Rossfeld Fm. in the upper part of the section under study have been studied taxonomically. One new ammonite taxon, Schrambachoceras weidichi gen. et sp. nov., has been deteremined. The ammonites enabled the inclusion of ammonite-bearing deposits in the international orthostratigraphic scale (Reboulet et al. 2011, Gradstein et al. 2012).

\section{Setting and sampling}

The locality of Schrambachgraben (Fig. 1) lies on the western slope of the Salzach River valley called Salzachtal, near the municipality of Kuchl, approximately $4 \mathrm{~km}$ south-southeast of Hallein, south of Salzburg (map sheet ÖK-50 Bl. 94 Hallein). The graben is oriented in the west-east direction, and the Schrambach mountain creek flows through it. In the studied section, there are two waterfalls, the Schrambach and Rossfeld waterfalls. The height of the steep wall of the Schrambach waterfall is approximately $60 \mathrm{~m}$. The exposed sediments largely belong to the Schrambach Formation and represent the type locality of the mentioned formation. The type locality can be easily observed from the Golling-Hallein main road (Bundesstrasse) (see fig. 1 in Rasser et al. 2003).
From the geological view, the Schrambachgraben section is a part of the Lower Tirolic Unit (Fig. 2), in the system of the Northern Calcareous Alps as shown by Bujtor et al. (2013), Frisch \& Gawlick (2003, fig. 1), Krische et al. (2013), Missoni \& Gawlick (2011, fig. 4), Piller et al. (2004), and others. The rectangle in Fig. 1c by Bujtor et al. (2013) corresponds to the range and gross palaeogeographical position of the studied section in the Schrambachgraben, which is of the same range and position as in the Leube Quarry in Gartenau near Salzburg (Bujtor et al. 2013).

If we neglect $10 \mathrm{~m}$ thick sequence outcropped in an isolated exposure in the lowermost part (which, according to Rasser et al. 2013 belongs to the lower part of the Oberalm Formation; GPS $47^{\circ} 38^{\prime} 43.81^{\prime \prime} \mathrm{N}, 13^{\circ} 6^{\prime} 17.78^{\prime \prime} \mathrm{E}$ ) the sequence thickness of the Schrambachgraben section attains more than 180 meters (GPS $47^{\circ} 38^{\prime} 40.48^{\prime \prime} \mathrm{N}$, $\left.13^{\circ} 7^{\prime} 8.09^{\prime \prime} \mathrm{E}\right)$. From the total thickness of the section under study, the lower 38.5 meters belong to the Oberalm Formation, and the remaining part belongs to the Schrambach Formation. After interruption in the sequence associated with a tectonic event (GPS $47^{\circ} 38^{\prime} 43.92^{\prime} \mathrm{N}$, $13^{\circ} 6^{\prime} 22.34^{\prime \prime} \mathrm{E}$ ), younger deposits belonging to the Rossfeld Formation are exposed (GPS 47 $38^{\prime} 43.77^{\prime \prime} \mathrm{N}$, $\left.13^{\circ} 6^{\prime} 18.05^{\prime \prime} \mathrm{E}\right)$. From these deposits, a portion approximately $16 \mathrm{~m}$ thick is accessible for direct study. 


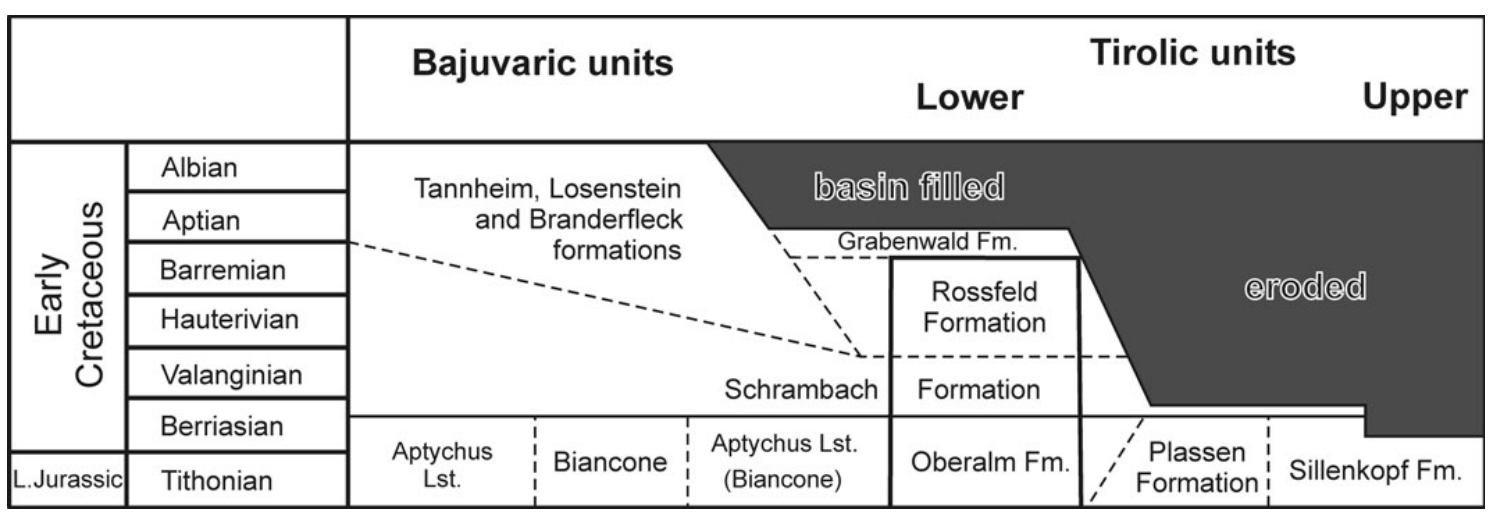

Figure 2. Mesozoic units in the NCA (modified after Frisch \& Gawlick 2003). Position of the section represent the rectangle define in the extra bold.

The Oberalm Formation (Lipold 1854, see Fig. 3) prevailingly consists of grey-white hemipelagic limestones, which are mottled in places, with partly indistinct lamination and often with a conchoidal fracture of limestones. In the section in the Oberalm Formation, we continuously obtained samples in the creek channel upwards in the stream. The samples for thin sections are designated "uw9-uw22", and samples for non-calcareous dinoflagellates are designated "uwd6-uwd20".

At $38.5 \mathrm{~m}$ of thickness above the base of the sequence studied (see Fig. 3), the first layers of rather dark marly limestones, which are silty on weathered surfaces, appear in the sequence. The number of layers increases gradually, whereas the amount of silty, light limestones decreases. This pattern is a part of the fluent transition from the Oberalm to the Schrambach Formation. The first layer of marly, dark coloured silty limestone we take as the base of Schrambach Formation. The Schrambach Formation is defined by Lipold (1854). At approximately $64 \mathrm{~m}$ of thickness of the section (in the lower waterfall), a more than $11 \mathrm{~m}$ thick, very conspicuous layer of silty marlstones (without limestones of Oberalm character) follows. This part represents the typical Schrambach Formation. However, several indistinct layers of grey-white hemipelagic limestones of the Oberalm type can still occur until an level 93 m of thickness (see Fig. 3).

The sequence of the Schrambach Formation exposed in the lower waterfall could not be directly documented. Along the right bank of the Schrambach creek (GPS $47^{\circ}$ $\left.38^{\prime} 40.23^{\prime \prime} \mathrm{N}, 13^{\circ} 7^{\prime} 3.61^{\prime \prime} \mathrm{E}\right)$, at the steep slope, it was possible to perform a documentation of the equivalent overlying beds in the waterfall. Samples "uw 23-uw 38" and "uwd21-uwd30" in the lower part of the Schrambach Formation were obtained at this location.

Rasser et al. (2003) discovered a side ravine (GPS $47^{\circ}$ $38^{\prime} 39.93^{\prime \prime} \mathrm{N}, 13^{\circ} 7^{\prime} 1.32^{\prime \prime} \mathrm{E}$ ) in which he documented another higher part of the section in the Schrambach Formation. This part corresponds to nearly the entire upper part of the sequence of strata outcropping in the lower waterfall.
Variegated (grey-green and violet-red mottled) silty-marly deposits occur approximately in the 75 to $93.5 \mathrm{~m}$ thickness level of the waterfall where samples designeted "wf1-wf 19" were obtained (see Fig. 3).

In the Schrambach Formation, above the last layer of erosion resistant limestone, a marly sequence predominates (GPS $\left.47^{\circ} 38^{\prime} 41.22^{\prime \prime} \mathrm{N}, 13^{\circ} 7^{\prime} 2.44^{\prime \prime} \mathrm{E}\right)$. This area is in the part under the Schrambach waterfall and consists of thin-bedded, typically light grey marlstones that weather to a brown colour and are intercalated with more resistant slab-like (to a thickness of $20 \mathrm{~cm}$ ) fine-grained silty limestones and sandy marlstones. Towards the overlying beds, the number of erosion resistant layers gradually diminishes. After reaching a thickness of approximately $114 \mathrm{~m}$ (see Fig. 3), brownish, shaly, silty marlstones predominate in the sequence. In the upper part of the section in the Schrambach Formation, these marlstones acquire a quite dominant position.

During the detailed lithological documentation of the section in the Schrambach Formation from the upper edge of the lower waterfall to its most accessible end (the length in the bed of creek was nearly $420 \mathrm{~m}$; GPS $47^{\circ} 38^{\prime} 44.58^{\prime \prime} \mathrm{N}$, $\left.13^{\circ} 6^{\prime} 22.76^{\prime \prime} \mathrm{E}\right)$, we have taken samples for thin sections for a microfacies study and for the determination of content of stratigraphically significant calpionellids and microfossils (samples designated "v1-v45"). We also obtained samples for non-calcareous dinoflagellates (samples designated "D1-D40"). A year later, we increased the density of sampling in the lower part of the section above the waterfall (in parts corresponding to a thickness of 105 to $132 \mathrm{~m}$ ) by obtaining samples designated "va-vj" and 3 samples designated "OVX" in the uppermost part of the Schrambach Formation.

In the overlying part of the section, the continuation of the Schrambach-type lithology is still evident, but the stream of the creek is completely impassable there. The inaccessible part of the section corresponds to an estimated thickness of approximately $40-50 \mathrm{~m}$. An accessible part extends just below the upper (Rossfeld) waterfall (GPS $47^{\circ} 38^{\prime} 43.81^{\prime \prime} \mathrm{N}$, 


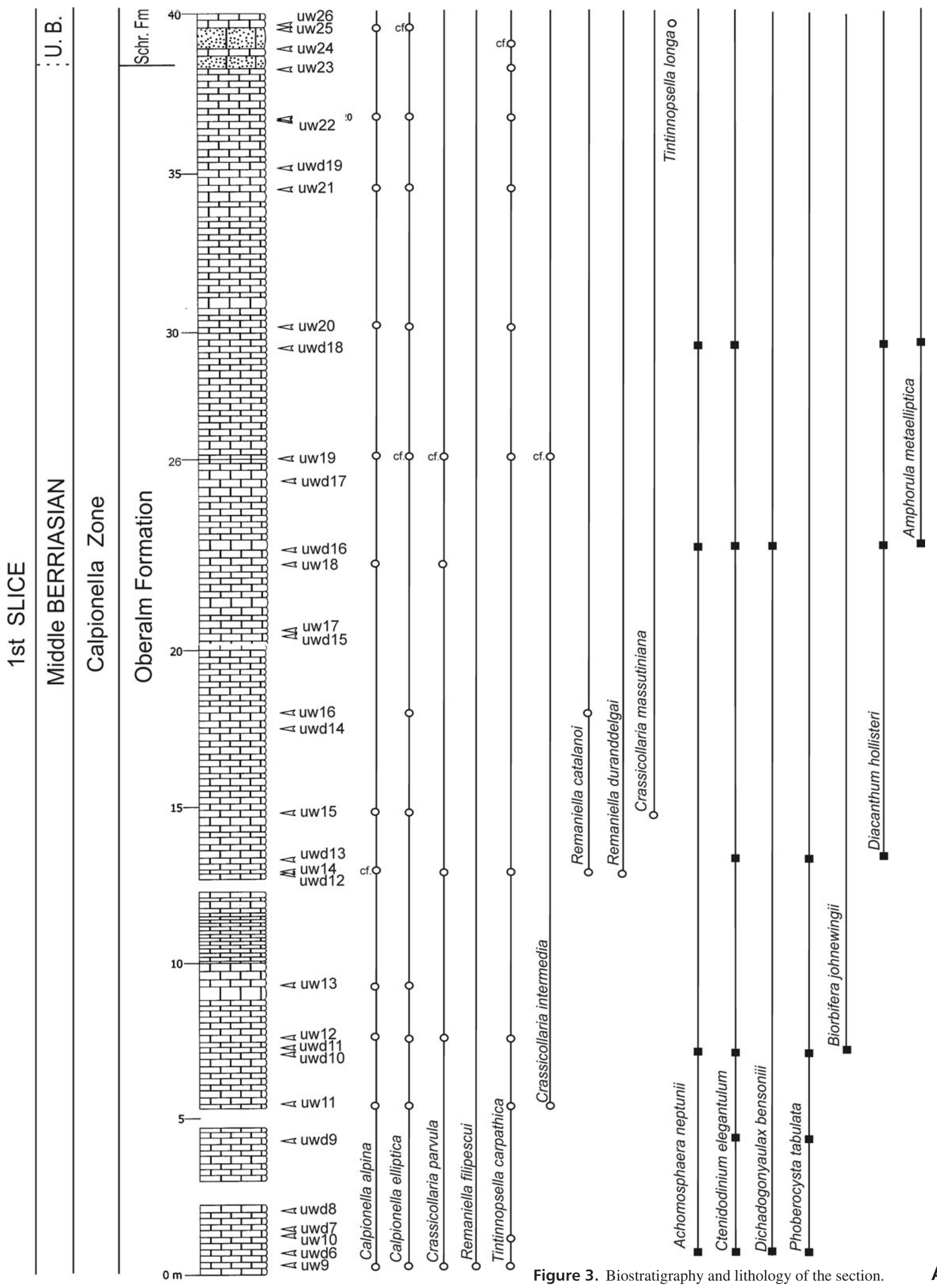


Daniela Boorová et al. • Biostratigraphy of the Lower Cretaceous Schrambach Formation
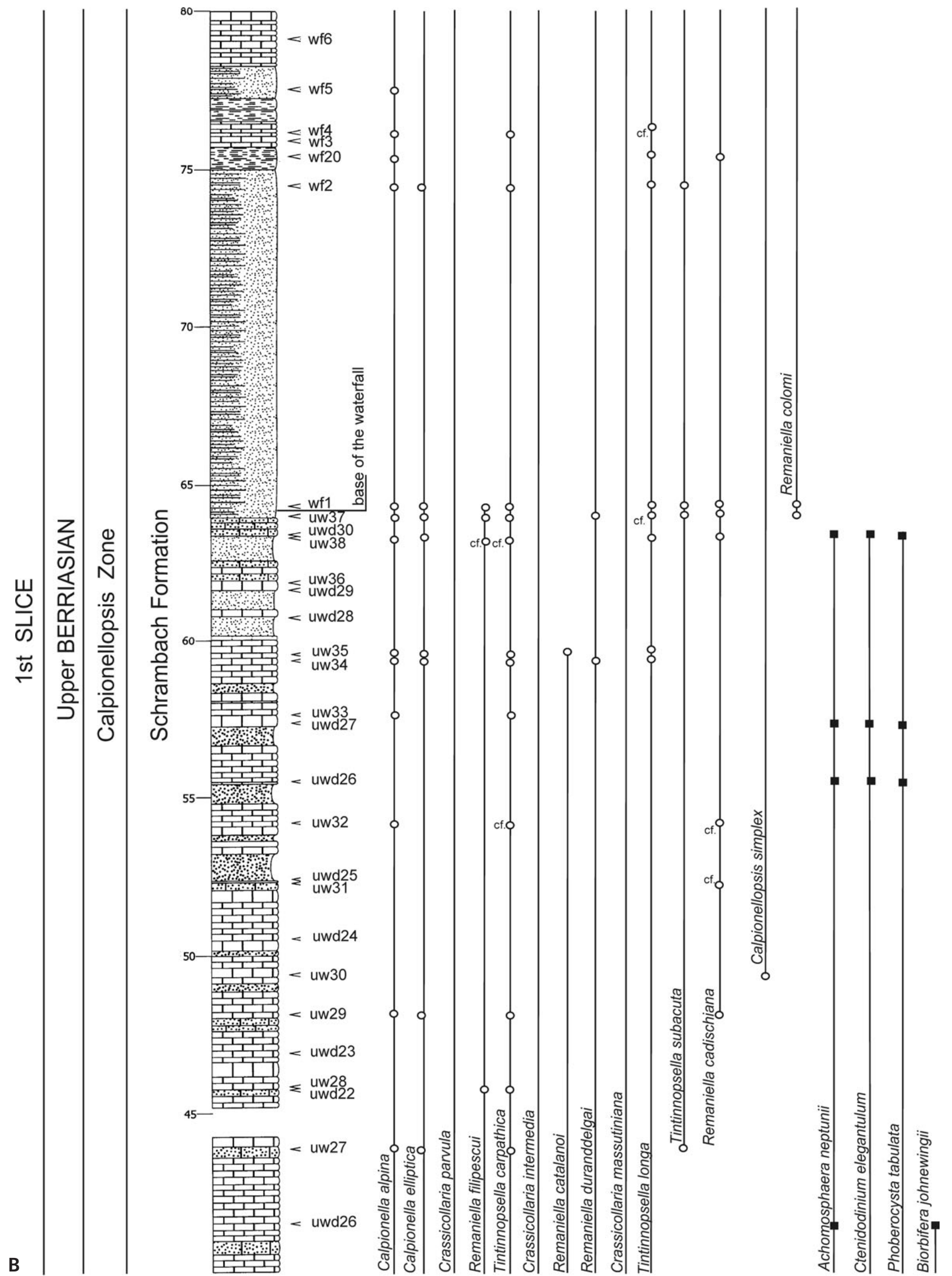
Bulletin of Geosciences • Vol. 90, 1, 2015
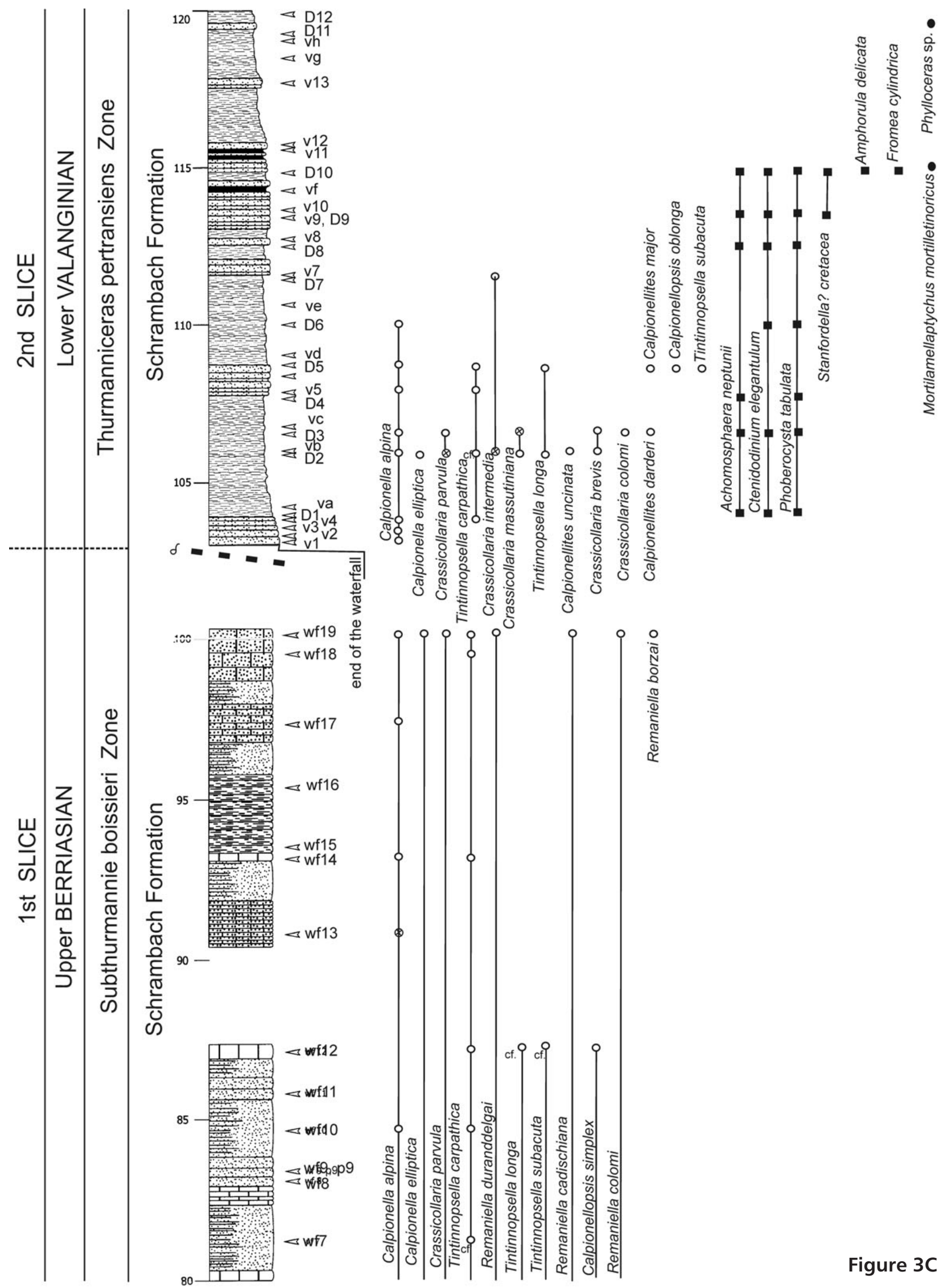

Figure $3 C$ 
Daniela Boorová et al. • Biostratigraphy of the Lower Cretaceous Schrambach Formation
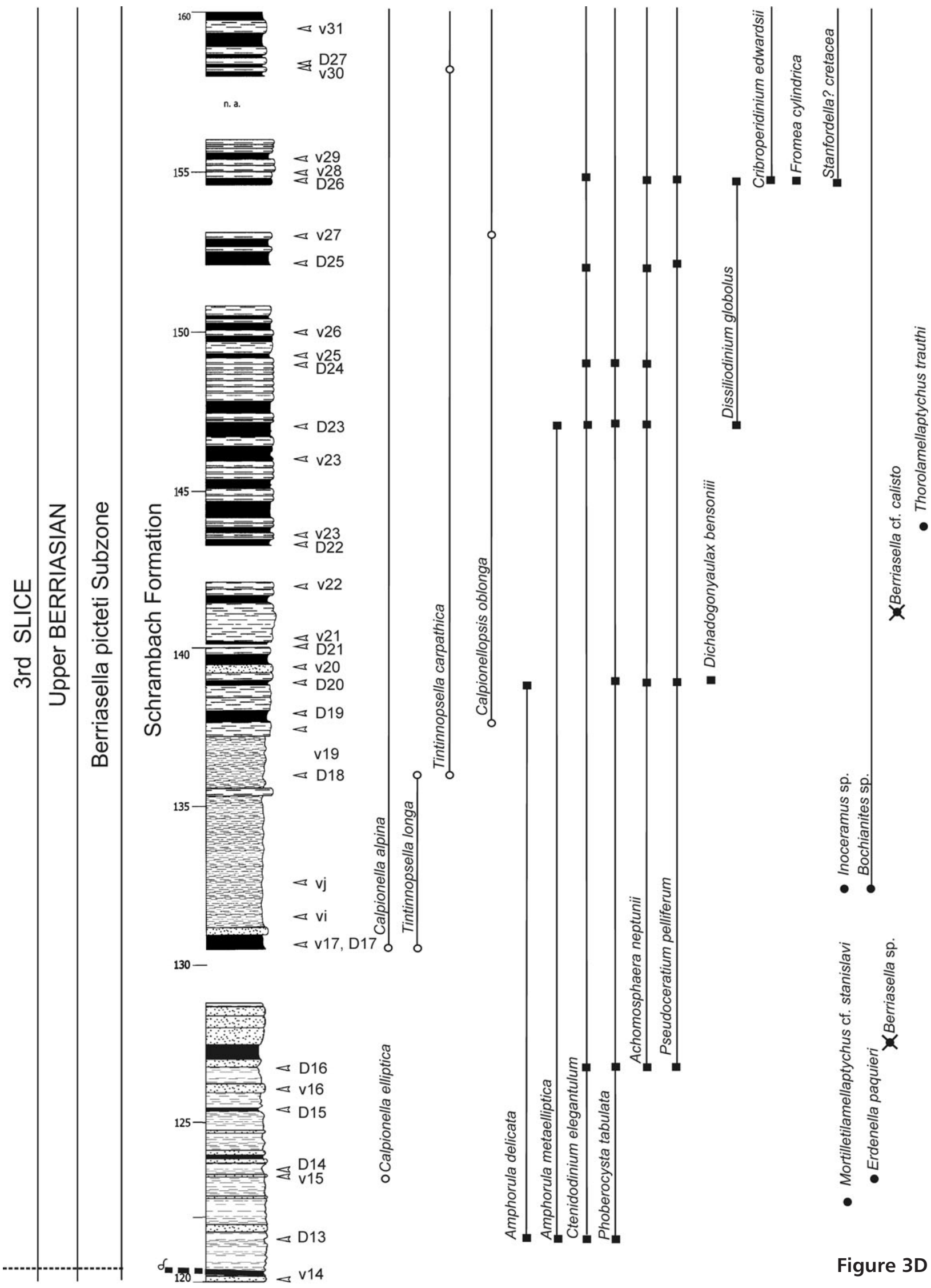

Figure 3D 


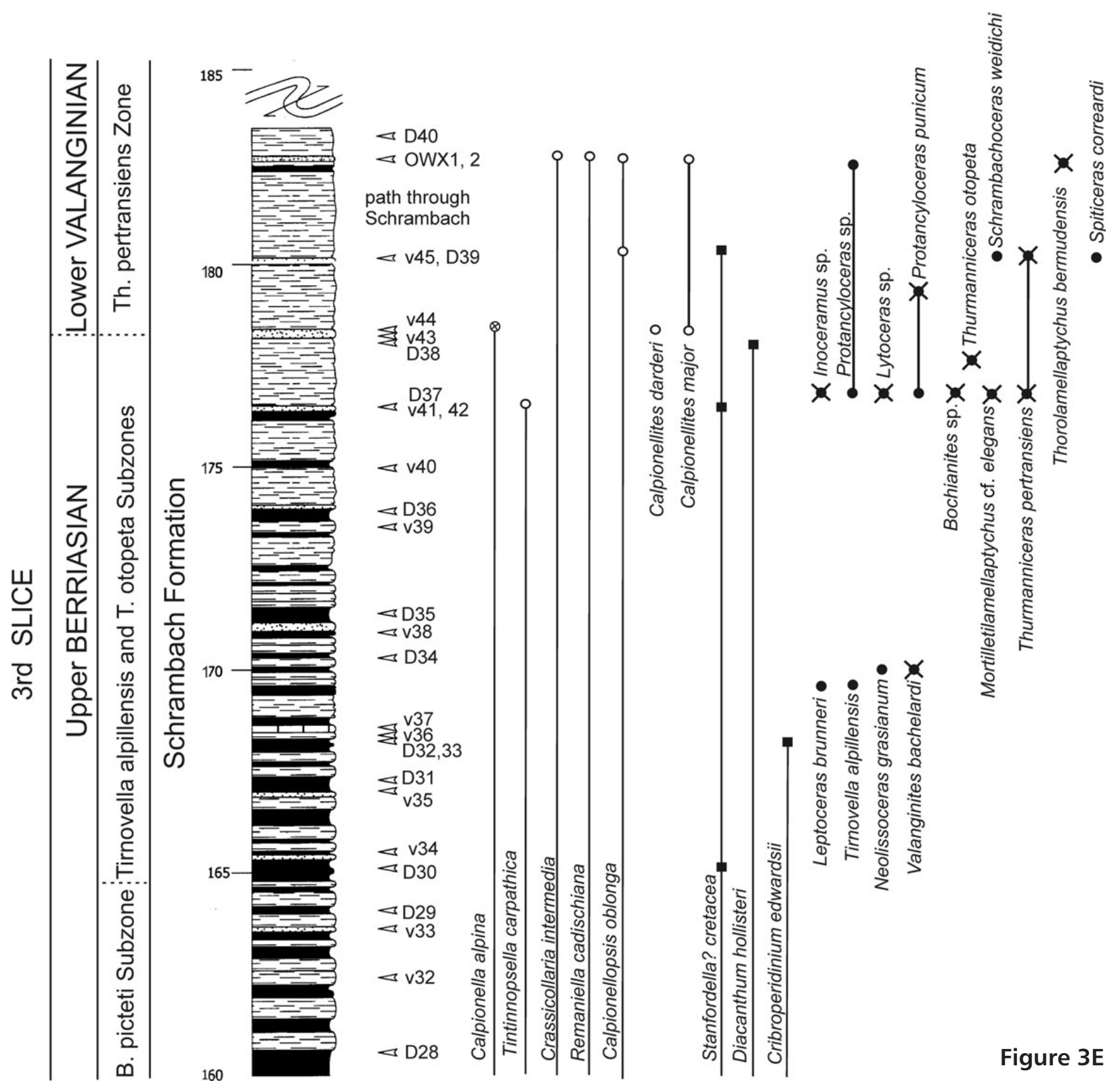

$\left.13^{\circ} 6^{\prime} 17.78^{\prime \prime} \mathrm{E}\right)$. These deposits belong already to Rossfeld Formation (Lillienbach 1830). Contact between Schrambach and Rossfeld formations is not accessible.

In the lowermost part of the Rossfeld Formation grey siltstones prevail. These siltstones are intercalated with slablike sandstones. At the base of the waterfall and at a height of approximately $2.5 \mathrm{~m}$, there are massive sandstones with grain sizes increasing towards the overlying beds. A unique feature of these deposits in the part with siltstones is the existence of several thin layers of clay-like, silty sandstones with claystone pebbles and plant debris. In the Rossfeld Formation, samples designated "rw1-rw4" were obtained for thin sections and samples "rwd1-rwd5" for non-calcareous dinoflagellates. Horizons designated "Ross1 and Ross2" represent layers with the occurrence of ammonites.

\section{Microfacies and micropaleontology}

Sediments of the Oberalm, Schrambach and Rossfeld formations were studied in thin sections from a microfacies and microbiostratigraphical viewpoint. To determine the microtexture of the sediments, we used a combined classification by Folk (1962) and Dunham (1962).

\section{Oberalm Formation}

The microscopic study indicated a more or less distinct "schlier-like" and/or "spotted" appearance of rocks caused by an irregular arrangement of allochems and various degrees of accumulation in a partly recrystallized groundmass. 


\begin{tabular}{|c|c|}
\hline \begin{tabular}{l|l}
10 \\
\end{tabular} & hemipelagic limestones \\
\hline 政 & variegated marlstones \\
\hline a: & sandy limestones \\
\hline : & sandy marlstones \\
\hline$-=-7$ & marlstones \\
\hline Fi: & sandy marlstones, thin bedded \\
\hline & silty marlstones, siltstones (in Rossfeld Fm.) \\
\hline ;:80 & sandstones \\
\hline O & tintinnids \\
\hline$\otimes$ & tintinnids in clasts \\
\hline - & dinocysts \\
\hline • & cephalopods \\
\hline$\gamma$ & macrofauna in debris \\
\hline
\end{tabular}

In certain thin sections, indications of microlamination are observed, occasionally caused by pyrite, which partly forms the filling of fossils (dominantly radiolarians) or locally impregnates the groundmass.

The allochems are typically recrystallized, more or less sorted, and a portion is partly plunged (amputated) into the groundmass or merges with it. The components occasionally show partial indications of alignment and/or are directed (e.g., sample "uw11") (Fig. 4A). The amount of biogens (allochems) in the individual samples varies. In addition to samples with a dense occurrence of fossil remnants, some with a lesser or even rare content occur. For example, samples "uw19" to "uw22" show distinct changes not only in the organic remnants frequency but also in the total character of the sediments studied.

From a textural point of view, the rocks belong to biomicrites / biomicrosparites (biogenic wackestone / rarely biogenic packstone). The microfacies are prevailingly radiolarian-calpionellid and are rarely radiolarianspiculitic-calpionellid. In certain samples, we encounter the problem of the small dimensions of micrite (mudstone) clasts and peloids. Some of the clasts and peloids small dimensions are most likely the result of partial groundmass recrystallization.

Dominating biogens are radiolarians (Fig. 4F), pre-

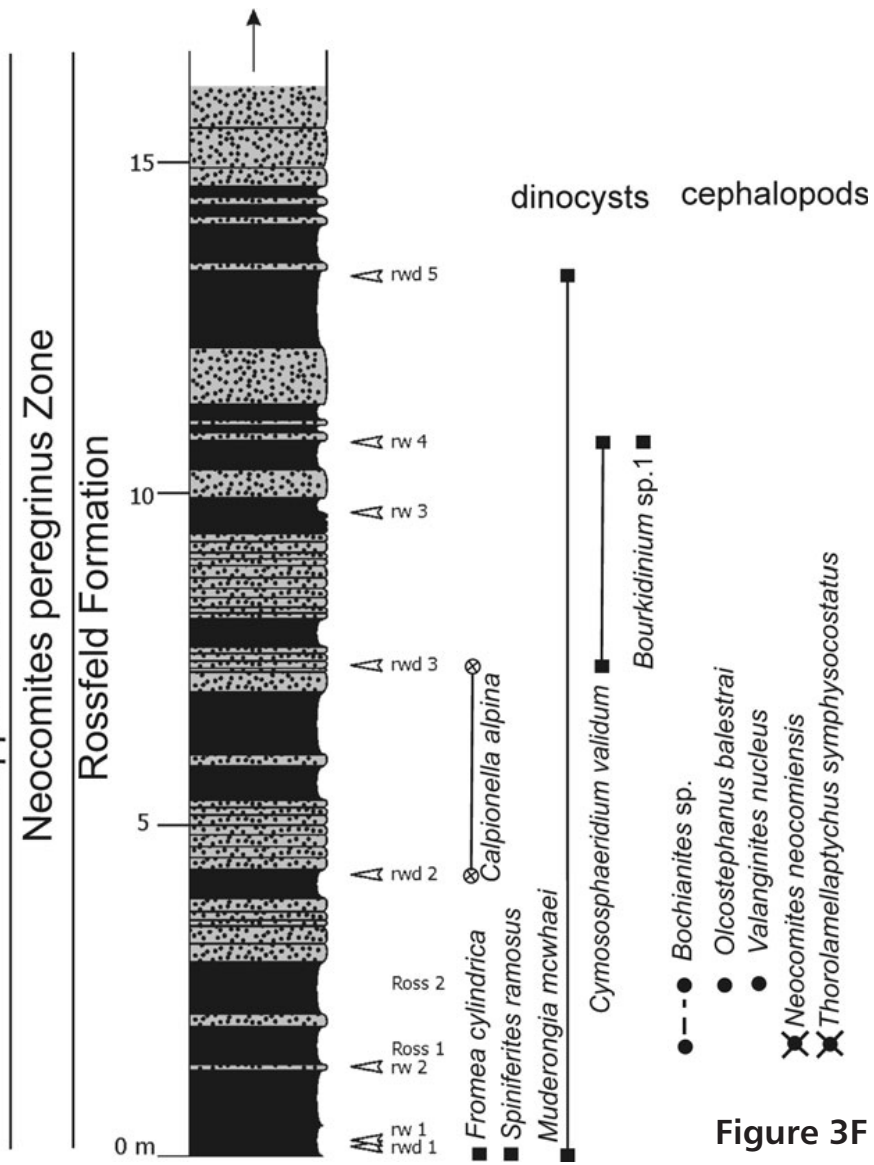

vailingly of the spumellarian type, with a very scarce and/or partly siliceous original filling (for example, "uw20"). Nassellarians are rarely preserved. The second most frequent organic remains are sponge spicules of several morphotypes.

In most of the samples, calpionellids (order Tintinnida Corliss) are rarely to scarcely found. The identification of calpionellids is often unfavourably influenced by the degree of their preservation. There are occasionally loricas and/or collars, partly plunged in the groundmass or with indications of deformation (e.g., "uw11, uw12, uw18, uw22") caused by transportation. Calpionellids are represented by specimens of the genera Calpionella Lorenz, Tintinnopsella Colom, and Remaniella Catalano and to a lesser amount by specimens of the genus Crassicollaria Remane, which most likely represents redeposits. The presence of the species Calpionella alpina Lorenz (Fig. 6B), C. elliptica Cadisch, Tintinnopsella carpathica Murgeanu \& Filipescu, Remaniella sp., R. catalanoi Pop, $R$. duranddelgai Pop, R. filipescui Pop (Fig. 6E) and, in certain thin sections, Crassicollaria parvula Remane ("uw12, uw14, uw18") was found in negligible amounts (typically one specimen), and/or specimens of this genus have been established. The identification of these specimens, due to the degree of their preservation, is ambiguous: 
?Crassicollaria parvula ("uw1, uw9"), Cr. cf. intermedia (Durand Delga) ("uw11, uw19"). The established assemblage indicates the standard calpionellid Calpionella Zone, Elliptica Subzone (in agreement with Reháková \& Michalík 1997), which, according to several authors (Grün \& Blau 1997, Reháková \& Michalík 1997, Andreini et al. 2007), begins in the uppermost part of the Lower Berriasian or in the Middle Berriasian (Pop 1994a, b, 1996, 1997) ranging to the end of the Middle Berriasian (Reháková \& Michalík, 1997) or to the lower middle part of the Middle Berriasian (Pop 1994a, b, 1996, 1997; Grün \& Blau 1997; Andreini et al. 2007).

The sporadic presence of the calcareous dinoflagellates Schizosphaerella minutissima (Colom) (Fig. 5C) has been established. In samples "uw15" and "uw20", the amount of calcareous dinoflagellates increased so significantly that the microfacies may be designated as radiolarian-schizosphaerellan one. In "uw14", Cadosina semiradiata fusca (Wanner) also occurs.

In the samples studied, filaments are a relatively more common biogen. Further established fossil remnants are present diachronously, typically in small to subordinate amounts and are not found in all of the samples studied. The fossil remnants belong to the aptychi, fragments of echinoderms, smooth-walled Ostracoda div. sp. or their valves, Globochaete alpina Lombard, benthic foraminifers (Lenticulina sp., ?Spirillina sp.), an echinoid spine ("uw14") and a fragment of a bivalve Inoceramus sp. shell ("uw10, uw2"). A common part of the samples is recrystallized detritus and/or biodetritus.

A thin section of sample "uw22"shows an alternation of several types of laminae of varying thickness (Fig. 4C), typically with a smooth transition, without sharp borders. We noticed lamina that differs from others primarily by the mode of fossilisation of the radiolarians in addition to the original siliceous filling (this was noticed also at the sponge spiculae). Radiolarians are filled atypically by micrite or microsparite with micritic rim. The material was redeposited. There is evidence of alignment, primarily visible at the sponge spicules. Allochems are densely ordered and typically touching. The texture is intrabiopelmicrosparite / intrabiopelmicrite (intraclast-biogenic-peloid packstone). The microfacies are radiolarian-spiculitic-calpionellid. Calpionellids are very scarcely found in these laminae. Calpionella alpina and C. elliptica were identified, and some are amputated by other allochems and/or deformed - ?Tintinnopsella carpathica. Further fossil remains are filaments, sporadical Schizosphaerella minutissima, part of a foraminifer Lenticulina sp., very scarce fragments of thick-walled bivalves and other recrystallized biodetritus or detritus.

In thin sections, these types of laminae alternate with the thinnest, further described laminae but border with and/or gradually pass into a lamina in which from its direction the number of biogens gradually decreases, nearly to their complete disappearance. This phenomenon primarily concerns radiolarians but also other components. Recrystallized biodetritus and/or detritus become prevalent. The groundmass is more or less recrystallized (microsparite). Siliceous filling of fossil remnants is absent. The alignment of individual allochems is distinct, which is also shown by the lengthened spindle shape of the radiolarians. Calpionellids are only represented by a solitary indeterminable form. Sponge spicules and filaments are present in these laminae from organic remains.

The thinnest observed laminae are of "obscured" intrapelsparite/intrapelmicrosparite texture (intraclastpeloid grainstone). The allochems are ordered relatively densely, quite commonly touching and more or less sorted. The clasts are small of micrite (mudstone) texture. Rare to scarce organic remains have been found after thorough study only. These remains are formed by radiolarians of the spumellarian and nassellarian type, which occasionally are partly pyritized, isolated Schizosphaerella minutissima and by a form of calpionellids, without closer identification. Highly recrystallized fragments, most likely of echinoderms, detritus and biodetritus, are present.

The presence of carbonate rhombohedrons, rarely of larger dimensions, is typical for the studied samples of the Oberalm Formation. Brown rims around the carbonate rhombohedrons are common. Pyrite is present relatively often. Clastic quartz, primarily of the aleuritic fraction, is mostly rare. Newly formed quartz and hydromicas are very scarce. Fe-pigment is also present.

\section{Schrambach Formation}

Between the Oberalm Formation and the Schrambach Formation, a conventional lithological boundary has been

Figure 4. A - alignment of allochems. Biomicrite/biomicrosparite (biogenic wackestone). Radiolarian-spiculitic-calpionellid microfacies. Sample "uw11". Oberalm Formation. • B - "schlier-like" character of limestone. Most probably there are traces after bioturbation. Sample "uw33". Schrambach Formation. $\bullet \mathrm{C}$ - laminated limestone. In the centre a thin lamina of intrapelsparite/intrapelmicrosparite texture (intraclast-peloid grainstone) is found. Sample "uw22". Oberalm Formation. • D - radiolarian-spiculitic-echinoderm microfacies. Sample "wf13". Schrambach Formation. • E - laminated sediment. Sample "wf15". Schrambach Formation. • F - recrystallized radiolarians of spumellarian and nassellarian type. Sample "uw9". Oberalm Formation. • G - undulated contact of laminae. In the lower lamina aligned aptychi are found. Sample "wf19". Schrambach Formation. • H - cluster of allochems of distinctly larger dimensions. Aptychi, Saccocoma sp., fragment of echinoderms in clast, which are "split" by aptychus. Sample "wf19". Schrambach Formation. 

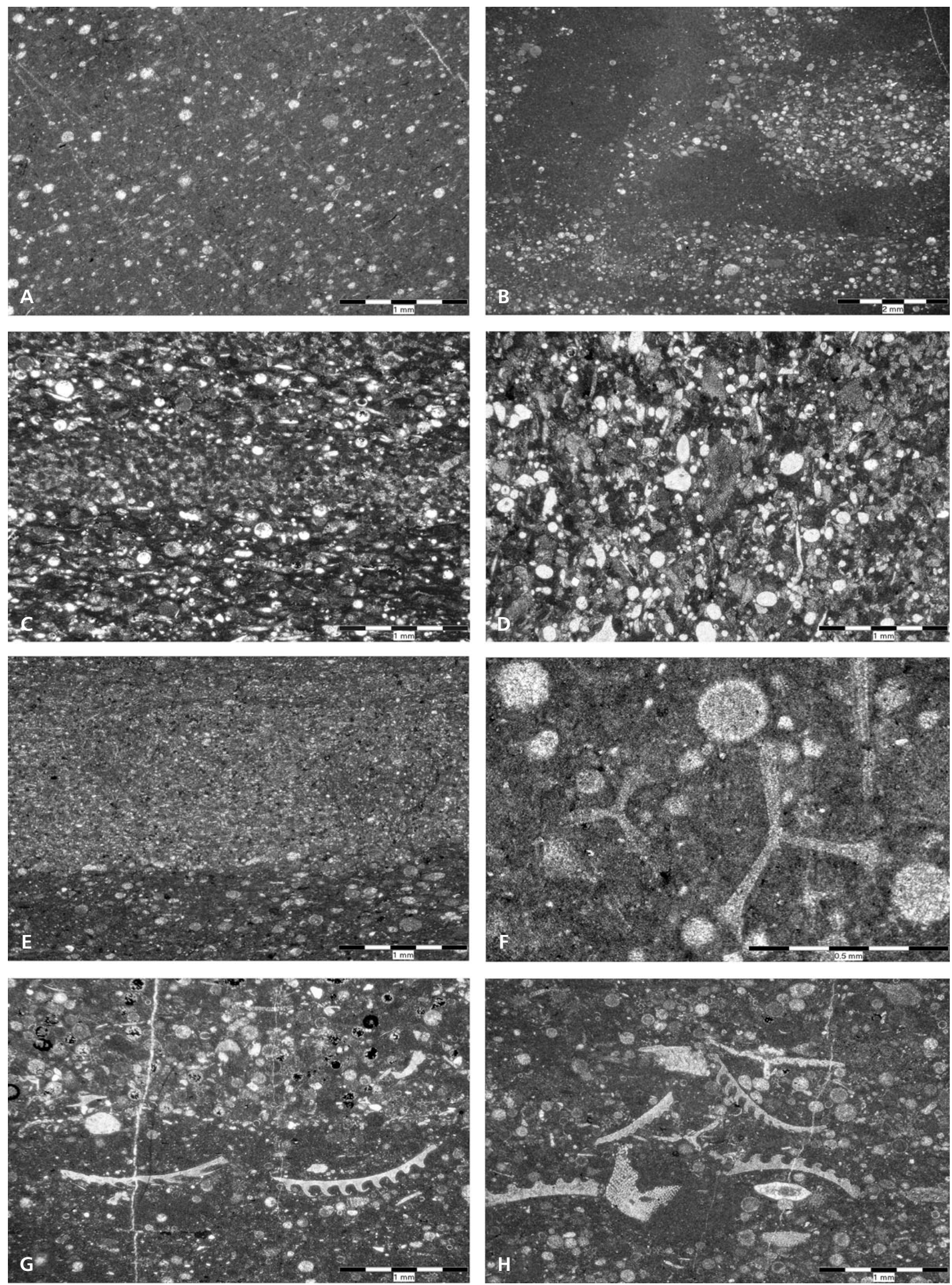
established (Fig. 3). In lower horizons of the Schrambach Formation, no distinct and/or essential changes are observed in the sediments compared with those of the Oberalm Formation. Calcareous dinoflagellates are an exception to this observation, as discussed below.

Over the laminated sediment ("uw22"), which represents the uppermost part of the Oberalm Formation, there are sediments ("uw23") with the same content of densely packed allochems (as in "uw22"). The allochems are typically in close contact and locally cut each other. Lamination disappeared (recorded indications of "incomplete microlamination"), and only slight signs of "schlier" caused by partial recrystallization of groundmass and smaller amounts of allochems in certain passages were observed. The individual components are typically directed. The filling of biogens is sporadically siliceous. The texture is, except for the field with a small amount of allochems ("schlier"), intrabiopelmicrosparite (intraclast-biogenicpeloid packstone / intraclast-biogenic-peloid wackestone). The microfacies are radiolarian-spiculitic-cadosinae. Periodically, it is hard to discern whether there are really clasts (typically of smaller dimensions) and peloids or whether these "allochems", or a portion of them, are a product of recrystallization. We also encounter this fact in further samples from overlying sediments of the Schrambach Formation bed sequence ("uw24, uw25, uw27").

As mentioned previously, in sample "uw23", an essential change in the quantitative share of calcareous dinoflagellates is observed. The form of Cadosina semiradiata fusca "ousts", substitutes Schizosphaerella minutissima and acquires a distinct prevalence. In the Berriasian, according to the calcareous dinoflagellata, Reháková (2000a) distinguished the Fusca Acme Zone [the uppermost part of the Middle Berriasian (the uppermost part of the Elliptica Subzone) to the middle of the Late Berriasian (the middle part of the standard Calpionellopsis Zone, the Oblonga Subzone)]. Based on the common to abundant occurrence of Cadosina semiradiata fusca, accepting the zonation by Reháková (1.c.) and according to the lithology, it may be assumed that the sediment ("uw23") is of Late Berriasian age. This stratigraphical position cannot be proved and confirmed by a fauna of calpionellids typical for the Late Berriasian; therefore, it is absent in this sample. Based on the mentioned information, we placed the conventional boundary between the Middle and Late Berriasian at the base of the bed, from which the sample "uw23" was obtained. This location is also the boundary conventionally established between the Oberalm and Schrambach formations. Cadosina semiradiata fusca also confirms its dominance in other studied samples (e.g., "uw27, uw28, uw29" [Fig. 5D], wf6, wf12, wf13b, wf14, wf15, wf18”).

Towards the overlying strata, sediments of the Schrambach Formation occasionally resemble or are identical microfacially, microtexturally and in the degree of preservation of individual components to "common" sediments of the Oberalm Formation. In certain cases, a "schlier-like" character (Fig. 4B) (in certain samples, this is most likely due to traces after bioturbation) and an alignment of allochems can be observed, the amount of which varies in the studied samples; this primarily concerns biogens.

The study of thin sections of the Schrambach Formation proved the same irregular alternation and/or recurrence of several microtextural and microfacial types, depending on the topical conditions of the sedimentation and on the content and arrangement of the allochems, as implied previously.

Microtexturally, the studied sediments most often belong to intrabiopelmicrosparites / intrabiopelmicrites (intraclast-biogenic-peloid wackestone / intraclast-biogenic-peloid packstone) and rarely to biomicrosparites (biogenic wackestone / locally biogenic packstone).

Radiolarian-spiculitic-calpionellid, cadosinae-radiolarian-spiculitic-calpionellid, calpionellid-radiolarian, calpionellid, radiolarian-spiculitic and radiolarian-cadosinaespiculitic microfacies were recorded, depending on their composition.

There was scarce or no calpionellid fauna in the samples in the lower part of the Schrambach Formation (up to approximately $83 \mathrm{~m}$ of thickness, see Fig. 3). Many forms cannot be identified unambiguously because of their unfavourable preservation (recrystallization, amputation, deformation; Fig. 6G) and unsuitable sections.

Calpionellids in the basal horizons of the Schrambach Formation ("uw23-uw26") are represented by Calpionella alpina, C. elliptica, Tintinnopsella carpathica, cf. Crassicollaria sp. and Tintinnopsella longa (Colom), which was recorded for the first time in sample "uw26". This form appears in the upper part of the Middle Berriasian. Considering the change in calcareous dinoflagellates

Figure 5. A - intrabiosparite (intraclast-biogenic grainstone) with sporadical peloids. Sample OVX1. Schrambach Formation. • B - indications of microlamination caused by inequal arrangement of abundant clastic quartzy admixture. Sample OVX2. Schrambach Formation. $\bullet$ C - Schizosphaerella minutissima (Colom) (upper part of the figure). Radiolarian-schizosphaerellan microfacies. Sample "uw 15". Oberalm Formation. • D - Cadosina semiradiata fusca (Wanner). Sample "uw29". Schrambach Formation. • E-Bonetocardiella conoidea (Bonet) approximately in the centre of the figure. Sample "wf19". Schrambach Formation. • F - "schlier-like" habit of sediment caused by irregular accumulation of allochems. Sample "rw1". Schrambach Formation. • G - almost perfectly worked up clast of limestone. In its center Cadosina semiradiata fusca (Wanner) occurs. Sample "wf19". Schrambach Formation. • H - recrystallized Trocholina sp. Sample "rw2". Rossfeld Formation. • I - fragment of macrofauna (in centre). Below it a clast of volcanic rock is found. Sample "rw3". Rossfeld Formation. 

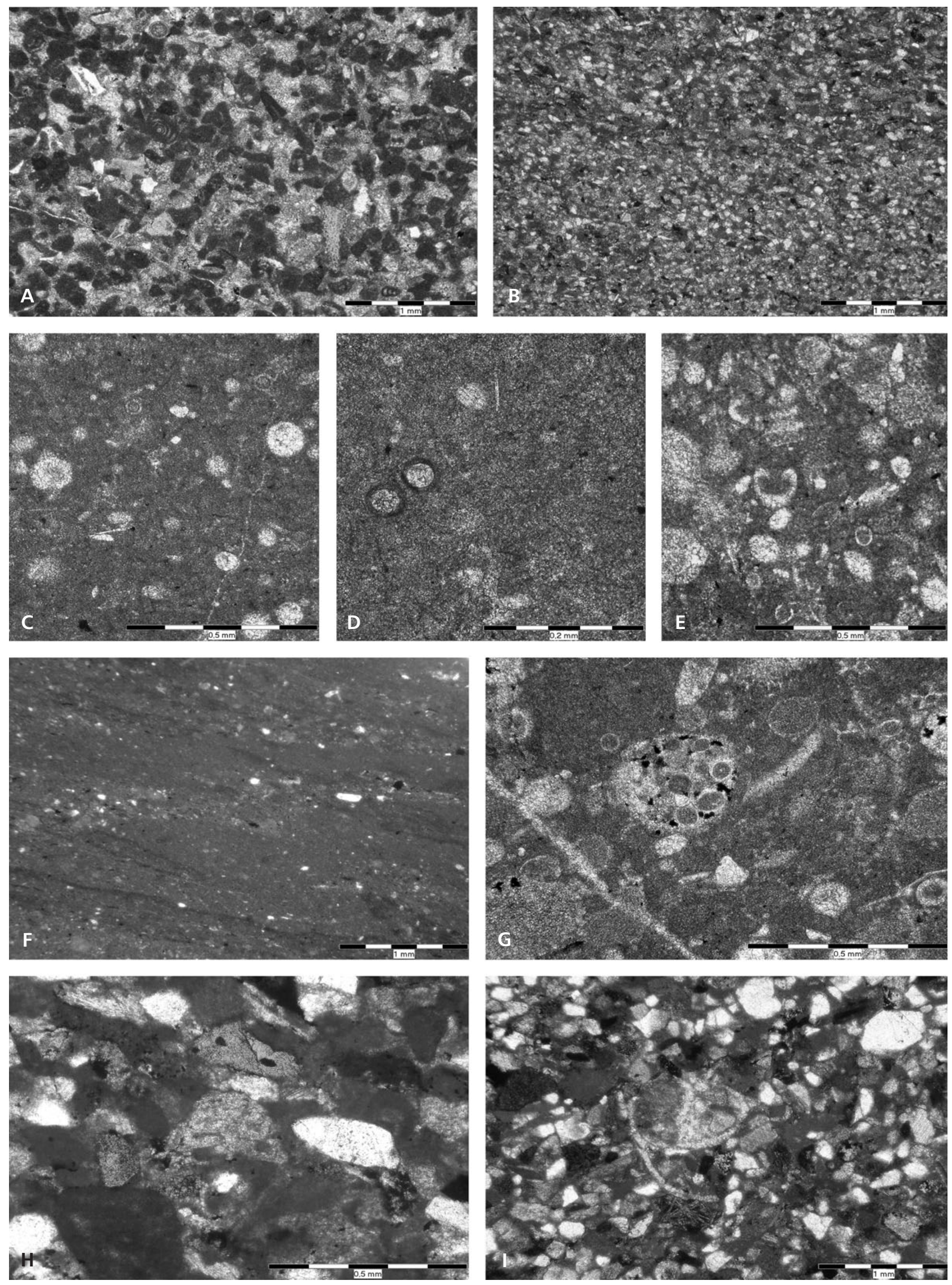
mentioned above and the minimum amount of calpionellids, and despite that the presence of the Late Berriasian index form belonging to Calpionellopsis Colom has not been established, we assume the "abandonment" of the Middle Berriasian standard Calpionella Zone, Elliptica Subzone. We found Calpionellopsis in the higher calpionellid zone, which represents the Late Berriasian (see Andreini et al. 2007, fig. 5). As a supporting argument, the first appearance of the form Tintinnopsella subacuta (Colom) in "uw27" is placed in the Late Berriasian (Pop 1994a). The first occurence of this species is connected with the Calpionelopsis Zone, the Oblonga Subzone.

In higher horizons, new forms of calpionellids, primarily of remaniellids, are gradually occurring (or reoccurring) with the previously mentioned association (Fig. 6A, I-L, N, O); these calpionellids include Remaniella filipescui, R. cadischiana (Colom) (Fig. 6F), $R$. duranddelgai (Fig. 6D), R. catalanoi, R. colomi Pop and $R$. borzai Pop.

In "uw30", the first isolated occurrence of Calpionellopsis simplex (Colom) has been established, indicating the Late Berriasian. The presence of Calpionellopsis oblonga (Cadisch) has been observed only in the upper parts of the Schrambach Formation (sample "D5", approximately in $109 \mathrm{~m}$ of thickness) in the second tectonic slice, in addition to others, associated with a form of the genus Calpionellites Colom, indicating Early Valanginian. Based on the mentioned data, it is evident that the calpionellid Calpionellopsis Zone is difficult to exactly define. Distinguishing individual subzones in the frame of this zone was not possible based on the material of the thin sections studied.

In addition to the biogens mentioned above (calpionellids, calcareous dinoflagellates, radiolarians, sponge spicules), in the rocks studied, there is an occurrence of rare to very scarce filaments, aptychi and/or their fragments, benthic foraminifers (textularoid form, Lenticulina sp., nodosariid form, Spirillina sp.), Globochaete alpina, ostracode valves, very scarce fragments of echinoderms, thick-walled bivalves, prisms of inoceramids, spines of echinoids, and incertae sedis (?"pseudoostracod") (Fig. 6T). In several thin sections, recrystallized cross sections or fragments, which most likely belong to the planktonic crinoid of Saccocoma sp., were observed. Recrystallized detritus and/or biodetritus are common to all of the samples studied.

Certain samples rarely display a relatively conspicuous difference to the characterization given above. Sample "uw37" is characterized by variegated, rich and relatively well-preserved fossil material. Allochems are found in a partially recrystallized groundmass. The allochems are rather unsorted, in irregular order, touching mutually in places and/or occasionally amputated. By their microtexture, the allochems are assigned to calpionellid-radiolarian biomicrites (calpionellid-radiolarian packstone / calpionellid-radiolarian wackestone) (Fig. 6A). Micrite (mudstone) clasts and peloids are found (intrabiopelmicrosparite intraclast-biogenic-peloid packstone / intraclast-biogenicpeloid wackestone) primarily in local passages with a more highly recrystallized groundmass.

The microfacies may be designated as calpionellidremaniellid, with regard to the biostratigraphical importance, and an uncommon amount of these microfossils is present compared with other samples studied. The occurrence of a rich calpionellid assemblage was established, as represented by Calpionella alpina (Fig. 6A), C. elliptica (Fig. 6I), Remaniella cadischiana, R. colomi, R. duranddelgai (Fig. 6D), R. filipescui, Tintinnopsella subacuta and T. cf. longa.

In addition to being common to abundant radiolarians, rare sponge spicules and other organic remains are sporadical forms of Saccocoma Agassiz. Highly recrystallized cross sections of these planktonic crinoids resembled certain scarcely found allochems and/or biodetritus, found in several preceding samples; their presence, however, could be confirmed unambiguously in this case only.

In "wf13", atypical and isolated radiolarian-spiculitic-echinoderm microfacies have been established (Fig. 4D). Relatively unsorted, densely ordered, more or

Figure 6. A - calpionellid-radiolarian biomicrit (calpionellid-radiolarian wackestone). Calpionella alpina Lorenz. Sample "uw37". Schrambach Formation. • B - Calpionella alpina (right) and Crassicollaria parvula (Remane) (left). Sample "wf19". Schrambach Formation. • C - Calpionellopsis oblonga (Cadisch) in remnant of micrite/microsparite groundmass. Sample OVX1. Schrambach Formation. • D - Remaniella duranddelgai Pop. Sample "uw37". Schrambach Formation. • E - Remaniella filipescui Pop. Sample "uw9". Oberalm Formation. • F - Remaniella cadischiana (Colom). Sample "wf19". Schrambach Formation. • G-deformed calpionellid. Sample "uw36". Schrambach Formation. • H - Crassicollaria massutiniana (Colom). Sample "D2". Schrambach Formation. • I - Calpionella elliptica Cadisch. Sample "uw37". Schrambach Formation. • J - Calpionella elliptica. Sample "uw29". Schrambach Formation. • K - Tintinnopsella carpathica (Murgeanu \& Filipescu) and Cadosina semiradiata fusca (Wanner) (over Tintinnopsella carpathica). Sample "uw37". Schrambach Formation. • L - Tintinnopsella carpathica. Sample "uw35". Schrambach Formation. - M - Tintinnopsella subacuta (Colom). Sample "D5". Schrambach Formation. • N - Tintinnopsella subacuta. Sample "wf1". Schrambach Formation. • O - Tintinnopsella longa (Colom). Sample "wf2". Schrambach Formation. • P - Calpionellites uncinata Cita \& Pasquare. Sample "D2". Schrambach Formation. • Q - Calpionellopsis oblonga. Sample "D5". Schrambach Formation. • R - Calpionellites major (Colom). Sample "D5". Schrambach Formation. • S - Calpionellites darderi (Colom). Sample "D3". Schrambach Formation. • T - incertae sedis (?"pseudoostracode"). Sample "uw35". Schrambach Formation. 
Daniela Boorová et al. • Biostratigraphy of the Lower Cretaceous Schrambach Formation
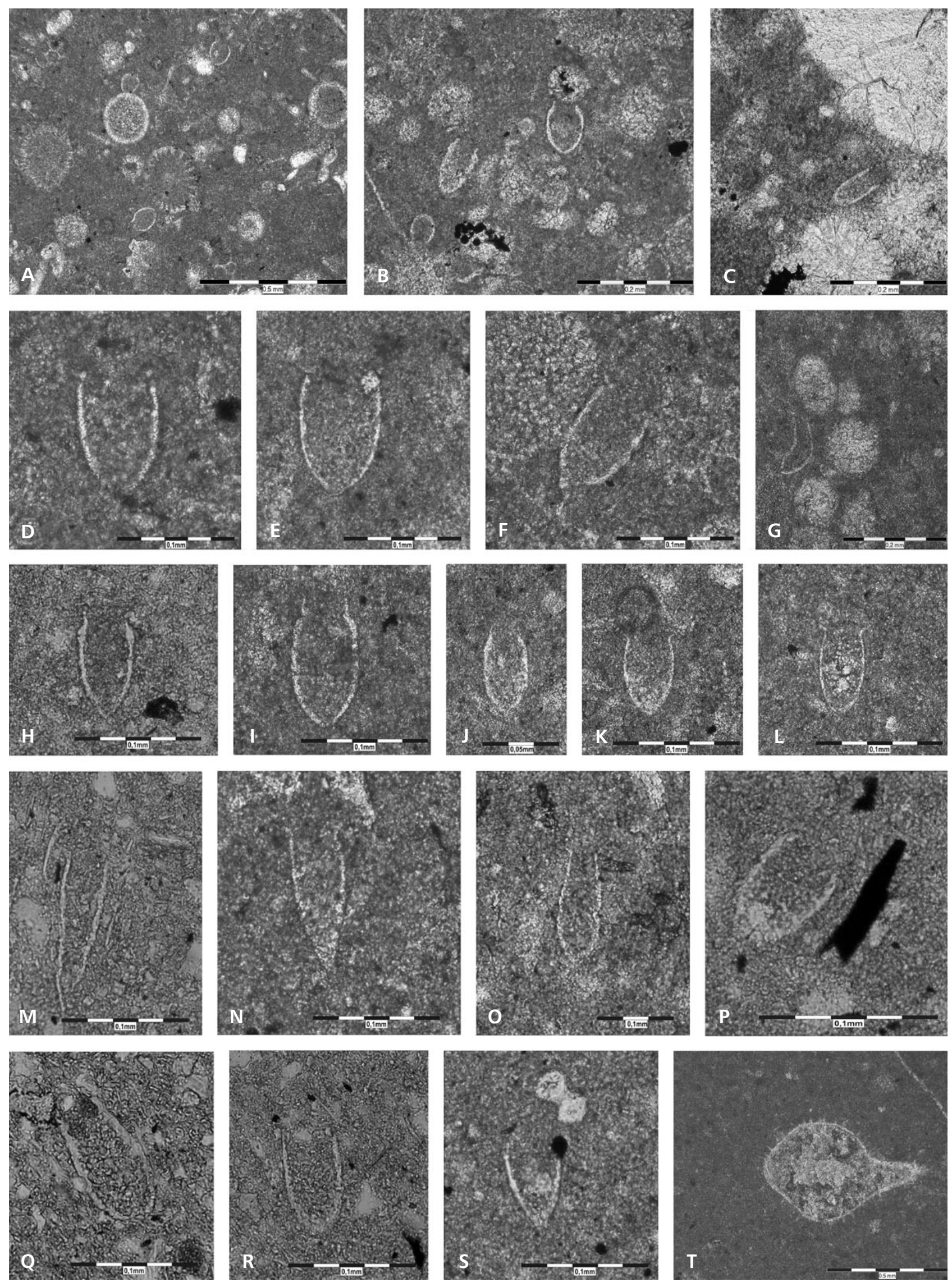
less aligned allochems are found. The texture is intrabiopelmicrosparite / intrabiopelmicrite (intraclast-biogenic-peloid packstone). Fragments of highly recrystallized echinoderms typically attain larger dimensions, contrary to other allochems. From more interesting fossil remains, which are only found very scarcely and/or in minimum amounts in the samples studied, echinoid spines and textularoid foraminifers of larger dimensions were recorded. Calpionellids were not observed.

In addition to other components, sample "uw37" and sample "wf19" contain an amount of diverse organic remains. In the thin sections (sample "wf19"), an undulated contact of two "laminae" and/or "beds" are typically observed (Fig. 4G). The contact is emphasized by an inequal quantitative share of allochems in the individual laminae. This inequality, however, changes quickly in the direction away from the contact, and the frequency of allochems distinctly increases continuously in the second "lamina", which, in texture, belongs to the intrabiomicrites (intraclastbiogenic wackestone / intraclast-biogenic packstone). The microfacies may be designated as calpionellid-radiolarianaptychus. The material is unsorted, redeposited, and displays alignment (Fig. 4G). Indistinct microlamination caused by a higher accumulation of aligned aptychi is observed.

The clasts are relatively indistinct, unsorted, well worked up, typically of micrite (mudstone), and rarely of biomicrite (biogenic wackestone) texture. Occasionally, due to the dull rim, it is problematic to elucidate whether a clast is really present.

Fossil remnants are represented by common to abundant radiolarians, previously mentioned aptychi and/or their fragments, planktonic crinoids of Saccocoma sp., fragments of echinoderms, shells of inoceramids, valves of ostracodes, filaments, sporadical calcareous dinoflagellates, sponge spicules, benthic foraminifers, and primarily common calpionellids. Calpionella alpina, C. elliptica, Tintinopsella carpathica and Remaniella duranddelgai were identified. Primarily aptychi, saccocoms and fragments of echinoderms attain larger dimensions, contrary to other biogens, and, in places, take part in the formation of irregularly shaped accumulations (i.e., sample "wf19", Fig. 4H).

In the second part of the thin section, allochems are typically more densely ordered than in the "lamina", as described above, and differ in the amount of individual biogens. With regard to the amount of well-preserved remaniellids, the microfacies also could be designated as remaniellan-radiolarian. The presence of Calpionella alpina, C. elliptica, Remaniella cadishiana, R. colomi, R. filipescui and a "redeposited" form of Crassicollaria parvula has been established. In this "lamina", one form of Bonetocardiella conoidea (Bonet) (Fig. 5E) was identified. The occurrence of this microfossil is interesting and unexpected because, according to the available data, its first appearance is placed in the Late Albian (e.g., Reháková 2000b).
Rock fragments were also recorded, not observed in other thin sections. There is a clast of sandy carbonate and/or calcareous sandstone, and a nearly perfectly worked up fragment of limestone with Cadosina semiradiata fusca is found (Fig. 5G).

Another type of lamination was observed in underlying sediments ("wf15", Fig. 4E) in which several laminae and/or microlaminae of varying thickness are found. The material in the laminae, the amount, size, and sorting in their frame varies, and, in places, it displays indications of alignment. The texture of essentially intrabiopelmicrosparite (intraclast-spiculitic-peloid wackestone) is present. Calpionellids were found in a negligible amount and are without stratigraphical value.

In all of the samples, the presence of common pyrite, which, in places, forms coatings, occasionally in the shape of strips ("uw34") and/or forms the filling of biogens, has been observed.

New forms represent rhombohedrons of carbonates in variable amounts. Micas are scarcely found, and glauconite is most likely common.

A distinct change in the microtexture, microfacies and/or a change in the content and essentially a lower quantitative share of allochems, dominantly of biogens, is observed in higher horizons of the Schrambach Formation above the lower waterfall in the second tectonic slice, from which samples with the designation " $D$ " were obtained (Fig. 3). The establishment of the presence of calpionellid forms of Calpionellites Colom is more important, which have enabled the stratigraphical ranging of the sediments studied in this part of the section. In addition to the calpionellid forms previously recorded in the lower horizons of the Schrambach Formation bed sequence, the zonal fossils of Calpionellites darderi (Colom) (Fig. 6S) and Cts. major (Colom) (Fig. 6R) were identified for the first time, indicating the Early Valanginian standard Calpionellites Zone (see Andreini et al. 2007). The individual subzones in the frame of this zone cannot be precisely delimited due to the very scarce occurrence of index forms and calpionellids on the whole. Based on the presence of calpionellids mentioned previously (from this perspective, the most important is sample "D5") and the presence of a further form of Calpionellites, which is represented by Calpionellites uncinata Cita \& Pasquare (sample "D2", Fig. 6P), sediments attributed to the Early Valanginian were investigated. A sequence of rocks is involved, the occurrence of which begins approximately $103 \mathrm{~m}$ from the beginning of the studied section in the direction toward the overlying strata. The precise thickness of the rocks, which would correspond to the Early Valanginian, could not have been determined based on the study of the thin sections.

The preservation of allochems, primarily of biogens, indicates the redeposition of material in this section of the Schrambach Formation. This transport is proved by the 
presence of deformed calpionellids, occasionally partly plunged allochems in the groundmass and the presence of most probably redeposited forms, which belong to crassicolarians with Crassicollaria brevis Remane, Cr. colomi Doben, Cr. intermedia, Cr. massutiniana (Fig. 6H) and Cr. parvula. In certain cases, the high quality of their preservation is surprising and, occasionally, it is problematical to discern whether they occur in the groundmass or in clasts. In addition to the calpionellids mentioned above, Calpionella alpina, Tintinnopsella carpathica, T. longa, T. subacuta (Fig. 6M), cf. Calpionellopsis simplex (?redeposited), Cs. oblonga (Fig. 6Q), Remaniella filipescui and cf. $R$. cadischiana are present.

The organic remains mentioned further (with the exception of "D5"), calpionellids not excluded, are typically scarcely found primarily in sediments in the lower horizons of the Schrambach Formation. There is a distinct reduction of radiolarians and sponge spicules. The presence of Globochaete alpina, calcareous dinoflagellates of Cadosina semiradiata fusca, C. semiradiata semiradiata Wanner, Schizosphaerella minutissima, smooth-walled Ostracoda div. sp. or ostracode valves, nannocones ("D3, D6"), parts of benthic foraminifer tests, prisms Inoceramus sp. shells, fragments of other thick-walled bivalves shells and echinoderms was established. In the samples studied, relatively common recrystallized detritus of small dimensions is found.

The groundmass is relatively recrystallized, and the allochems contained within are irregularly ordered sometimes more or less and are relatively aligned. In certain samples the original texture is obscured, hardly legible. In sample "D10", relatively well worked up clasts of a micrite (mudstone) texture occur in such an amount that they deserve to be mentioned related to texture. The microfacies, as far as it can be established, is calpionellid and/or calpionellid-dinoflagellate ("D5").

A more or less common, exceptionally high admixture of relatively sorted clastic quartz with an undulatory extinction of aleuritic and sandy fraction is present; locally, its larger accumulations were recorded ("D5").

Authigenic quartz has been found. New forms are also represented by carbonate rhombohedrons. Pyrite is common, very scarcely copying fossil remains. A variable amount of micas has been established. Glauconite and rusty-brown minerals (indet) are present very scarcely.

From the lithological perspective, in the sequence of the strata of the Schrambach Formation, several horizons of silty shaly marlstones appear. These marlstones are characteristic of the sequence of strata exposed at the higher part of the Schrambachgraben section.

At approximately the level of the right subsidiary tributary (corresponding to deposits 120-122 m thick), the sequence of strata changes more markedly. Softer silty, shaly marlstones occur more frequently in which macrofauna pe- riodically appears, especially Late Berriasian ammonites. Calpionellids occur only exceptionally, and non-calcareous dinoflagellates are more abundant.

According to biostratigraphic data, especially according to the ammonites, it is evident that above the tectonic slice with the micropalaeontologically documented Early Valanginian (e.g., samples "D2, D3, D5"), the Upper Berriasian sediments appear again.

In thin sections from sediments occurring in the highest of the Schrambach Formation horizons, three samples with the designation OVX1 (2 thin sections) and OVX2 were studied. An intrabiosparite texture (intraclast-biogenic grainstone) with sporadical peloids (Fig. 5A) is characteristic of these sediments. The groundmass is partially recrystallized. Scarcely local irregular passages with remnants of micrite and/or microsparite groundmass typically with ill-preserved calpionellids (calpionellid biomicrite / calpionellid biomicrosparite; calpionellid wackestone) (Fig. 6C) were recorded. We identified Remaniella cadischiana, Calpionellopsis oblonga (Fig. 6C) and one cross-section of Calpionellites major and a redeposit represented by Crassicollaria intermedia. It is occasionally problematic to unambiguously establish whether calpionellids are part of a clast or found in the groundmass.

More or less sorted allochems are ordered somewhat equally and sometimes more densely; sporadically, they touch.

The clasts are of a micrite (mudstone) and only scarcely biomicrite (biogenic wackestone) texture, and they are more or less worked up. Organic remains in clasts are primarily represented by calpionellids. Calpionella alpina, Calpionellopsis oblonga and cf. Cps. simplex were identified. In addition, echinoderms, part of a benthic foraminifer test and undetermined biodetritus and/or detritus were recorded.

Organic remains in the groundmass are represented by the benthic foraminifers Dorothia oxycona (Reuss), Textularia div. sp., Gaudryina sp., Lenticulina sp., Spirillina sp., Anomalina sp., miliolid forms or parts of their tests and other forms, radiolarians of spumellarian type with original siliceous filling, fragments of echinoderms, aptychi and/or their detritus, small fragments of bryozoans, shells of bivalves Inoceramus sp., very scarcely cross sections resembling cf. Saccocoma sp. and fragments of shallow-water organisms. The occurrence of very scarce calcareous dinoflagellates with Cadosina semiradiata fusca, C. semiradiata semiradiata, and Cadosina fusca fusca Wanner was established. For the first time, Cadosina semiradiata cieszynica (Nowak) was found in the samples studied.

Pyrite, which forms small irregular surfaces, is present and fills up parts of foraminifer tests or is freely "scattered" in the groundmass.

In sample OVX1, scarce clastic quartz of a sandy fraction is found, thus differing from sample OVX2 (Fig. 5B) 
in which its distinctly increasing amount was observed; clastic quartz represents its essential component. The inequal arrangement of the quartz occasionally causes microlamination and/or its indications. Fe-minerals are found, which occasionally cause the rusty-brown colour of the test walls in miliolid foraminifers.

Sediments of the uppermost levels of the Schrambach Fm. are of Early Valangin age, based on the identified calpionellids of the standard calpionellid Calpionellites Zone, Major Subzone.

In the entire rock sequence of the Oberalm and Schrambach formations, at the Schrambachgraben section, we encounter (apart from exceptions) a lack of calpionellids and their poor preservation (unsuitably oriented sections, recrystallization, amputation, deformation) (Fig. 6G). This fact, together with the transportation of the material and/or the redeposition of fossil remains, including calpionellids, occasionally causes problems establishing the stratigraphical position of sediments studied based on calpionellids.

\section{Rossfeld Formation}

The Rossfeld Formation occurs in the uppermost horizons of the bed sequence at the section Schrambachgraben (Fig. 3). A microscopic study of the sample "rw1" shows that fields are present in which allochems are relatively evenly "scattered" in contrast to passages with sediments of "schlier-like" habitus caused by the piling up of components in irregular, occasionally warped "nests" and/or up to "incomplete" microlaminae, alternating with fields, nearly without allochems (Fig. 5F). These fields are at places of lenticular shape.

The microstructure is primarily composed of intrapelbiomicrite (intraclast-peloid-biogenic wackestone). The groundmass is partly recrystallized. The components are typically relatively small, more or less sorted and, in places, display indications of alignment. Micrite (mudstone) clasts are present.

Biogens are relatively rare. Radiolarians of the spumellarian type, sponge spicules, calpionellids and a benthic foraminiferas of the nodosariid type were scarcely observed. Common fine recrystallized detritus is found.

An admixture of clastic quartz, with undulatory extinction of the aleuritic to sandy fraction is present. Pyrite forming coatings and scarce glauconite was found.

Sample "rw2" has a distinctly different character. In texture, it belongs to intrabiomicrosparites / locally intrabiosparites (intraclast-biogenic packstone / locally intraclast-biogenic grainstone). The groundmass is partly recrystallized. More or less sorted allochems are typically densely ordered, commonly touching, and occasionally mutually amputated; signs of their alignment are observed.
Relatively well worked up clasts of limestones with micrite (mudstone), without the presence of allochems, are dominating. Calpionellids have been found only very scarcely, and Calpionella alpina was identified. In one fragment, an ostracode valve and most likely a benthic foraminifer cf. Spirillina sp. have been established. Peloids are found sporadically.

Fossil remains in the groundmass are most often recrystallized fragments of echinoderms (also a columnal of crinoid), benthic foraminifers [Dorothia oxycona, Gaudryina sp., Lenticulina sp., partly amputated Spirillina sp., Trocholina sp. (Fig. 5H), textularoid and other forms], rare aptychi, cross sections of planktonic crinoids of the genus Saccocoma, very scarce radiolarians, sponge spicules, an echinoid spine, and a fragment of a thick-walled bivalve shell.

An admixture of unsorted, irregularly scattered clastic quartz is typical, with undulatory extinction of the sandy sporadically aleuritic fraction, which is mostly quite angular. Pyrite is common in the form of coatings and/or rarely as a filling of biogens. Common glauconite and a rustybrown mineral (unidentified) and very scarce feldspars are present.

Compared with sample "rw2", a more variegated spectrum of densely ordered (packed) components is found in sample "rw3". The sample contains a richer admixture of unsorted quartz of a sandy fraction with undulatory extinction. In addition to carbonate clasts of micrite (mudstone) texture, further fragments, not observed previously, are found among others also of volcanic origin (Fig. 5I). There were also fragments with biomicrite texture (calpionellid wackestone), and Calpionella alpina was identified in them.

Organic remains in the groundmass are fragments of echinoderms, benthic foraminifers (textularoid and highly arched form - ?Trocholina sp.) and a fragment of macrofauna (Fig. 5I). As in the preceding samples, pyrite, glauconite and feldspars are present.

In the thin sections, no fossil remains have been found, which would permit the establishment of the age of the Rossfeld Formation.

\section{Non-calcareous dinoflagellate cysts}

All of the analyzed samples of the Oberalm Formation ("uwd6-uwd21") contain well-preserved dinoflagellate cysts (Table 1, Figs 7, 8). In addition to the cysts, acritarchs and inner walls of foraminifera (microforaminifera) are often present, which indicate redeposition of shallow marine material. The predominant part of all of the samples is a material of terrestrial origin, namely brown wood particles and cuticles; quite sporadically, pollen grains and spores occur.

In samples from the part below the waterfall and from the waterfall ("uwd6-uwd30"), dinoflagellate cysts, characteristic of both the Upper Jurassic [e.g. Amphorula meta- 
elliptica, Nannoceratopsis gracilis (Fig. 7P), N. pellucida, Systematophora orbifera and S. penicillata] and, predominantly, the Berriasian [Ctenidodinium elegantulum (Figs 7K, F), Diacanthum hollisteri, Phoberocysta neocomica (Fig. 7O), Muderogia simplex, Systematophora areolata (Fig. 8O), and others] appear. Index species, the first occurrences of which characterise the Tithonian/Berriasian boundary (Monteil 1992, Stover et al. 1996), are abundant here. This characterisation is especially the case with the first occurrences of the representatives of Circulodinium distinctum (Fig. 7A), Ctenidodinium elegantulum, Scriniodinium campanula (Fig. $7 \mathrm{H})$, Hystrichodinium pulchrum (Fig. 7G), and H. voigtii. According to Leereveld (1995), the first occurrence of the species Achomosphaera neptunii (Fig. 8B) is connected to the lower part of the Middle Berriasian (Subthurmannia occitanica ammonite Zone) along with the first occurrence of Dichadogonyaulax bensonii. However, according to Monteil (1992, 1993), these species appear from the upper part of the Early Berriasian (Berriasella jacobi ammonite Zone). From this observation, it can be expected that the base of the section belongs to the higher part of the Early Berriasian and to the Middle Berriasian. Dinoflagellate cyst contents of other samples obtained from the waterfall as far as its middle part do not differ markedly. The presence of Kleithriasphaeridium fasciatum (Fig. 7L) in sample uwd16 is of interest; according to Monteil (1992), it is bound to the Tirnovella otopeta ammonite Zone (latest Berriasian).

In a continuation of the preceding section, at the edge of the lower waterfall, which belongs to the Schrambach Formation ("uwd1-D13", Fig. 7, Table 1), dinocyst assemblages are enriched with the new species Circulodinium brevispinosum, Hystrichosphaerina schindewolfii (Fig. 8L), Kleithriasphaeridium corrugatum, Muderongia longicorna (Fig. 7E), Systematophora scoriacea (Fig. 8M), and Tanyosphaeridium isocalamus. Here, the occurrence of the typical Jurassic species Systematophora penicillata ends; this is a case of dinocysts, the first occurrences of which characterise the Berriasian (Leereveld 1995, 1997; Skupien \& Smaržová 2011).

In sample "D16", the presence of the species Pseudoceratium pelliferum (Fig. 8G) can be regarded as an indicator of the Late Berriasian, more specifically from the upper part of the Berriasella picteti ammonite Subzone (Leereveld 1995, 1997; Monteil 1992); however, according to Monteil (in Stover et al. 1996), it belongs to the Valanginian.

With reference to the first occurrences of Dissiliodinium globolus (in sample "D23"), Cribroperidinium edwardsii ("D26") and the last occurrence of the Amphorula metaelliptica (in sample "D23", Fig. 7M), the Early Valanginian can be expected in the upper part of the section formed by the Schrambach Formation (Leereveld 1997, Stover et al. 1996). According to Leereveld (1997), the species Dissiliodinium globolus appears from the upper part of the Thurmanniceras pertransiens ammonite Zone. According to Monteil (1993), A. metaelliptica occurs in the Late Berriasian for the last time. The abundant presence of Stanfordella? cretacea (Fig. 8K, N) appears in sample "D26". The first occurrence of this species is indicative of Early Valanginian (Leereveld 1997). This piece of data contradicts the ammonites found in the section that still belong to the Late Berriasian. However, in the framework of the study by Leereveld (1997), data on dinocysts from the ammonite Tirnovella otopeta Zone (subzone of uppermost Berriasian at present) are missing. Thus, D. globulosus and $S$. cretacea occur in the Late Berriasian for the first time. A very similar occurrence was observed in the studied area earlier (Boorová et al. 1999) when dinoflagellates were correlated with calpionellids.

From the lower part of the Rossfeld Formation, which forms the end of the section, 5 samples were analyzed ("rw1-rw5", Table 1). Dinoflagellate cysts are abundant again; pollen grains and spores are present more frequently. Many dinoflagellate cysts typical for Berriasian or Early Valanginian no longer occur. Bourkidinium sp. 1 of Leereveld (1997), Cymososphaeridium validum, Muderongia mcwhaei, and Spiniferites ramosus appear stratigraphically as the most interesting ones. Through them, the Late Valanginian age of the sediments can be derived (Leereveld 1995, 1997; Skupien \& Vašíček 2002). Cymososphaeridium validum, and Muderongia mcwhaei are most abundant in the Late Valanginian deposits of the Western Carpathians (Skupien \& Smaržová 2011, Svobodová et al. 2011).

In the Lower Cretaceous sediments of the Oberalm and Schrambach formations, the presence of representatives of Nannoceratopsis (N. gracilis, N. pellucida; Fig. 7P, Q) is of interest. These species are dinoflagellate cysts typical for the Middle Jurassic; only in the case of the species N. pellucida is the last occurrence known from the Kimmeridgian. The presence of this species in Lower Cretaceous sediments of the area observed had been studied earlier (Boorová et al. 2000). It is interesting that no other Jurassic types of dinoflagellates proving redeposition have been found.

\section{Taxonomy of cephalopods}

The standard division of the order Ammonitina into four suborders according to Wright et al. (1996), i.e., Phylloceratina, Lytoceratina, Ammonitina and Ancyloceratina, has been subsequently modified to varying extents recently (Kvantaliani et al. 1999, Kakabadze et al. 2005, Klein 2005, Fischer \& Gauthier 2006, Vermeulen 2006, Mikhailova \& Baraboshkin 2009 or Arkadiev \& Bogdanova 2012). Concerning the taxonomy of ammonites found in the Schrambachgraben, we respect the basic classification 
by Wright et al. (1996). In accordance with the Code of Zoological Nomenclature (1999, p. 117), we use the suffix -oidea for the category of superfamily. The division into lower taxons is based herein, with several exceptions, on Klein (2005) and Klein et al. (2007), and others.

To keep this contribution as short as possible, the synonymies of described species contain only the reference to papers in which the species was described and illustrated for the first time, the most recent ones, and those being of regional interest or important for discussion.

In the descriptions of species in the "Measurement" paragraph, the typical symbols for dimension parameters of ammonite shells are used: $\mathrm{D}=$ shell diameter, $\mathrm{H}=$ whorl height, $\mathrm{U}=$ umbilicus width. Because all of the shells are deformed, the width of the whorls could not be measured.

The biostratigraphic data in the descriptions, i.e., ammonite zones and subzones, follow the latest zonation of the ammonites of the Mediterranean area, according to Reboulet et al. (2011).

Subclass Ammonoida Zittel, 1884

Order Ammonitida Zittel, 1884

Suborder Ammonitina Zittel, 1884

Superfamily Perisphinctoidea Steinmann, 1890

Family Olcostephanidae Haug, 1910

Subfamily Spiticeratinae Spath, 1924

\section{Genus Spiticeras Uhlig, 1903}

Type species. - Ammonites spitiensis Blanford, 1864.

\section{Spiticeras (S.) cf. correardi Djanélidzé, 1922}

Figure 10B

1922 Spiticeras Correardi Kilian in litt.; Djanélidzé, p. 160, pl. 18, figs 3a-c.

1960 Spiticeras correardi (Kilian). - Nikolov, p. 198, pl. 26, fig. 3.

?1961 Spiticeras correardi Kil. - Eristavi, p. 85, pl. 1, fig. 4.

2005 Spiticeras correardi Djanélidzé. - Klein, p. 52 (cum syn.).
Material. - The only rather well preserved, but heavily deformed sculpture mould (spec. GBA 2009/007/2).

Description. - A half-involute shell with vaulted, secondarily squeezed whorls. The umbilicus is rather narrow. The sculpture is characterised by rather dense, bounded ribs inclined to the mouth that run by twos to threes from considerably small umbilical tubercles. Around the periphery, the number of ribs of the initial bundle increases up to five by bifurcation or by insertion. Conspicuous constrictions in the number of 2 to 3 per whorl are present that are inclined strongly to the mouth; the last constriction indicating the mouth is the strongest. On either side, a strong rib limits the constriction. On the backside of the constrictions, up to 5 shorter ribs abut that fill the space created by the different inclines of the ribs and the constrictions. In the vicinity of the mouth, the tubercles fade out, and the ribs weaken.

Measurements. - Due to deformation, it is not useful to measure the typical dimensional parameters. The shell reaches the maximum diameter of approximately $52 \mathrm{~mm}$. At the diameter of approximately $46 \mathrm{~mm}, 12$ umbilical tubercles fall per half-whorl.

Remarks. - Heavy deformation of the described specimen obstructs precise determination. Because of both the density of the peripheral ribs and a narrower umbilicus, it is close to Sp. multiforme Djanélidzé, to a certain extent. The last-mentioned species, however, differs by sparser umbilical bullae and most likely by a straighter run of constrictions.

Distribution. - The precise stratigraphical position of $S p$. correardi is unknown in the literature. The position of species is described from France and Bulgaria (probably from the Berriasian/Valanginian boundary). A poorly preserved specimen is described and illustrated by Eristavi (1961) from the Slovakian Central Carpathians.

Occurrence. - Debris in the outcrop of the Schrambach Formation in the slope above the Schrambachgraben section in the uppermost accessible part of the section (Early Valanginian). The deposits roughly correspond to the

Figure 7. Dinoflagellate cysts. The species name is followed by the sample location. Scale: $20 \mu$ m. • A - Circulodinium distinctum (Deflandre \& Cookson, 1955) Jansonius, 1986. Sample "uwd10". Oberalm Formation. • B - Systematophora penicillata (Ehrenberg, 1843) Sarjeant, 1980. Sample "uwd6". Oberalm Formation. • C - Cometodinium habibii Monteil, 1991. Sample "uwd 9". Oberalm Formation. • D - Systematophora sp. Sample "uwd5". Oberalm Formation. • E - Muderongia longicorna Monteil, 1991. Sample "uwd9”. Oberalm Formation. • F - Ctenidodinium elegantulum Milioud, 1969. Sample "uwd9". Oberalm Formation. • G - Hystrichodinium pulchrum Deflandre, 1935. Sample "uwd16". Oberalm Formation. • H - Scriniodinium campanula Gocht, 1959. Sample "uwd16”. Oberalm Formation. • I, J - Diacanthum hollisteri Habib, 1972. Sample "uwd16". Oberalm Formation. • K - Ctenidodinium elegantulum Milioud, 1969. Sample "uwd21". Oberalm Formation. • L - Kleithriasphaeridium fasciatum (Davey \& Williams, 1966) Davey, 1974. Sample "uwd16". Oberalm Formation. • M - Amphorula metaelliptica Dodekova, 1969. Sample "uwd21". Oberalm Formation. • N - Cribroperidinium orthoceras (Eisenack, 1958a) Davey, 1969a. Sample “uwd16". Oberalm Formation. • O - Phoberocysta neocomica (Gocht, 1957) Millioud, 1969. Sample "uwd27". Schrambach Formation. • P - Nannoceratopsis gracilis Alberti, 1961. Sample "D4". Schrambach Formation. • Q - Nannoceratopsis sp. Sample "D4". Schrambach Formation. 
Daniela Boorová et al. • Biostratigraphy of the Lower Cretaceous Schrambach Formation
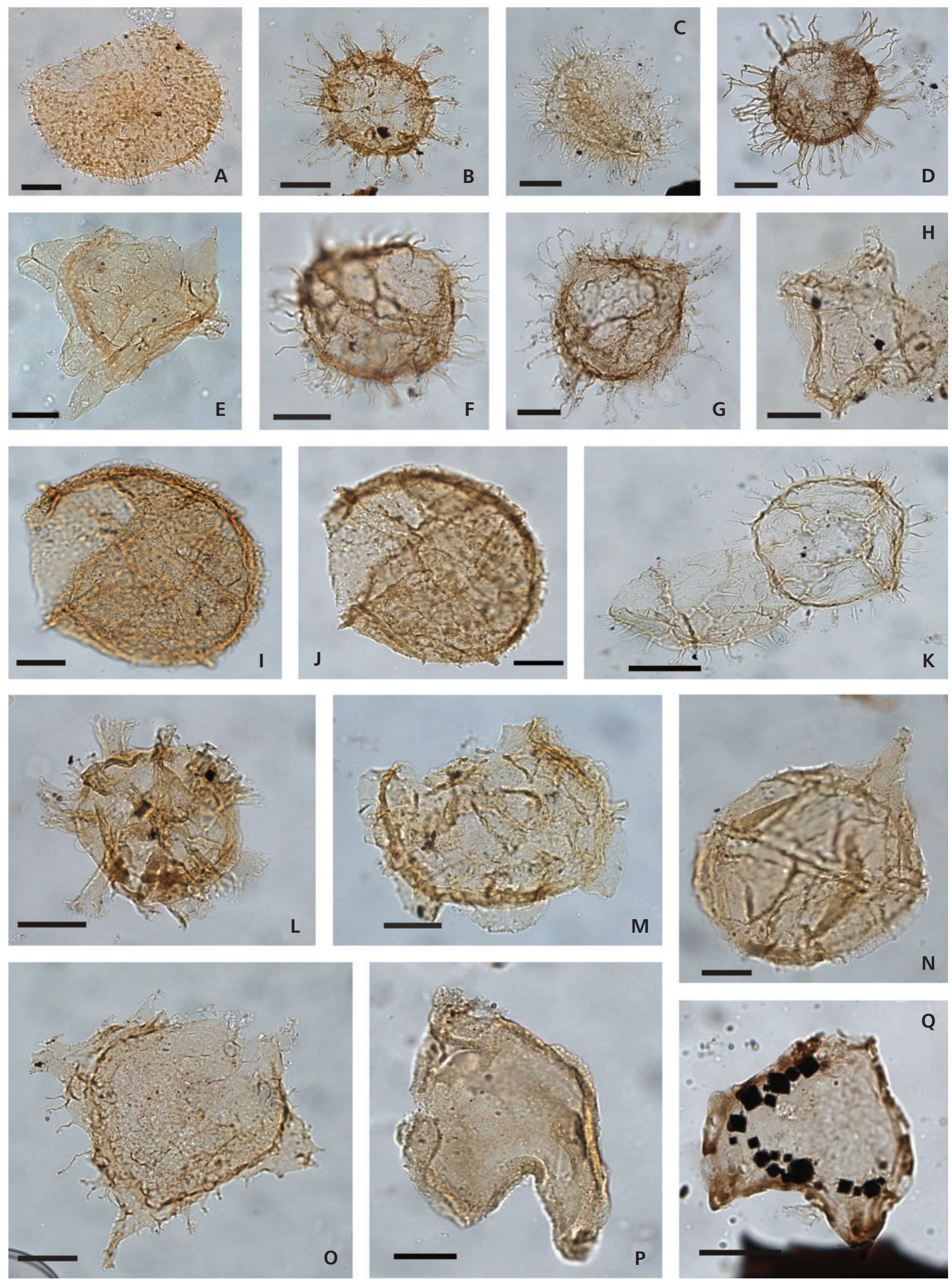
Table 1. Qualitative distribution chart of dinoflagellate cyst taxa.

\begin{tabular}{|c|c|c|c|c|c|c|c|c|c|c|c|c|c|c|c|c|c|c|c|c|c|c|c|c|c|c|c|c|}
\hline 产 & $\frac{0}{3}$ & $\frac{m}{3}$ & $\frac{0}{0}$ & $\frac{\infty}{\Xi}$ & $\begin{array}{l}\bar{\partial} \\
\vdots \\
ٍ\end{array}$ & 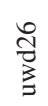 & $\frac{\widehat{\partial}}{\partial}$ & 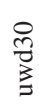 & $\bar{z}$ & & I & 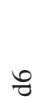 & 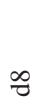 & $g$ & $\stackrel{0}{\ni}$ & $\frac{m}{\partial}$ & $\underset{\sigma}{\sigma}$ & ิㅡ & ฮี & & తf & Ð & & $\ddot{\partial}$ & 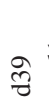 & $\exists=$ & 索光 & $\frac{\tilde{o}}{\stackrel{0}{*}}$ \\
\hline$*$ & & & & & & & & & & & & & & & & & & & & & & & & & & & & 1. Kleithriasphaeridium suevicum \\
\hline$*$ & & & & & & & & & & & & & & & & & & & & & & & & & & & & 2. Microhystridium pyramidispinosum \\
\hline$*$ & & & & & & & & & & & & & & & & & & & & & & & & & & & & 3. Muderongia spp. \\
\hline$* *$ & & & & & & & & & & & & & & & & & & & & & & & & & & & & 4. Circulodinium spp. \\
\hline$*$ & $*$ & & & & & & & & & & & & & & & & & & & & & & & & & & & 5. Tehamadinium dodekovae \\
\hline$*$ & $*$ & & & $*$ & & & & & $*$ & & & & & & & & & & & & & & & & & & & 6. Systematophora penicillata \\
\hline$* *$ & & & & & & & $*$ & & & & & & & & & $*$ & & & & & & & & & & & & 7. Exiguisphaera phragma \\
\hline$* *$ & $*$ & & $*$ & & & * & & & $*$ & & & & $*$ & $*$ & $*$ & $*$ & & & & & & & & & & & & 8. Gonyaulacysta spp. \\
\hline$*$ & & & * & & * & & & & & & & & & & $*$ & & & * & & & & & & & & & & 9. Dichadogonyaulax bensonii \\
\hline$*$ & $*$ & & & & & $*$ & & & $*$ & & & & $*$ & & $*$ & & $*$ & $*$ & & & & & & & & & & $\begin{array}{l}\text { Systematophora sp. A of Monteil } \\
\text { (1993) }\end{array}$ \\
\hline$* *$ & & & $*$ & $*$ & $*$ & & & & $*$ & * & $*$ & $*$ & $*$ & $*$ & & $*$ & $*$ & $*$ & $*$ & $* *$ & $*$ & $*$ & * & & & & & 11. Hystrichodinium pulchrum \\
\hline$* *$ & $*$ & $*$ & & & & & * & & & & & & & & & & & & & & & & & $*$ & & & & 12. Sentusidinium spp. \\
\hline$* *$ & $*$ & & $*$ & $*$ & $*$ & $*$ & * & $*$ & $*$ & $*$ & $*$ & $*$ & & $*$ & $*$ & $*$ & * & & & & $*$ & & & & $*$ & & & 13. Cometodinium habibii \\
\hline$*$ & $*$ & & $*$ & $*$ & & & & $*$ & & & & & & & & & & & & $*$ & & & & & $*$ & & & 14. Cribroperidinium orthoceras \\
\hline$* *$ & $*$ & $*$ & $*$ & $*$ & $*$ & & & & $*$ & $*$ & . & $*$ & & $*$ & 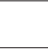 & $*$ & ; & $*$ & & $* *$ & $*$ & $*$ & & & $*$ & & & 15. Systematophora areolata \\
\hline$*$ & $*$ & & $*$ & $*$ & $*$ & $*$ & $*$ & $*$ & $*$ & $*$ & $*$ & & $*$ & $*$ & $*$ & & $*$ & * & $*$ & $* \quad *$ & 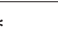 & $*$ & $*$ & & $*$ & $* *$ & $*$ & 16. Achomosphaera neptunii \\
\hline$* *$ & $*$ & $*$ & $*$ & $*$ & & $*$ & * & $*$ & $*$ & * & & $*$ & * & * & * & $*$ & * & & $*$ & $* *$ & $*$ & $*$ & * & & * & & * & 17. Ctenidodinium elegantulum \\
\hline$* *$ & & & & & & $*$ & $*$ & & $*$ & $*$ & $*$ & $*$ & $*$ & $*$ & $*$ & $*$ & $*$ & $*$ & $*$ & $* *$ & & & $* *$ & $* *$ & & & $*$ & 18. Systematophora scoriacea \\
\hline$*$ & & & & & & & & & & & & & & & & & & & & & & & & & & & $*$ & 19. Systematophora spp. \\
\hline$* *$ & $*$ & $*$ & $*$ & & & $*$ & $*$ & $*$ & $*$ & * & $*$ & $*$ & $*$ & $*$ & $*$ & $*$ & $*$ & $*$ & $*$ & $* *$ & $*$ & $*$ & $*$ & & & $* *$ & $* *$ & 20. Phoberocysta tabulata \\
\hline$*$ & & & & & & & $*$ & & & & & & & & & & & & & & & & & & & & & 21. Hystrichosphaerina? orbifera \\
\hline$*$ & & & & & & & & & & & & & & & $*$ & & & & & & & & & & & & & 22. Prolixosphaeridium mixtispinosum \\
\hline$*$ & $*$ & & & & $*$ & $*$ & * & $*$ & & * & & $*$ & & $*$ & & & & $*$ & & & $*$ & $*$ & * & & $*$ & & & $\begin{array}{l}\text { Prolixosphaeridium sp. A of } \\
\text { Monteil (1993) }\end{array}$ \\
\hline$*$ & & & & & & & & & & & & & & & $*$ & & & & & & & & & & & $*$ & & 24. Wallodinium krutzschii \\
\hline$*$ & & & & & & & & & $*$ & & $*$ & & $*$ & & $*$ & $*$ & & & & & & & & & & & $*$ & 25. Muderongia longicorna \\
\hline & * & & & & & & & & & & & & & & & & & & & & & & & & & & & 26. Bourkidinium granulatum \\
\hline & * & & & & & & & & & & & & & & & & & & & & & & & & & & & 27. Ctenidodinium ornatum \\
\hline & * & & & & & & & & & & & & & & & & & & & & & & & & & & & 28. Muderongia simplex \\
\hline & $*$ & & & & & & & & & & & & & & & & & & & & & & & & & & & 29. Systematophora palmula \\
\hline & $*$ & & & & $*$ & & & & & & & & & & & & & & & & & & & & & & & 30. Biorbifera johnewingii \\
\hline & $*$ & & & & & & $*$ & & & & & & & & & $*$ & & & & & $*$ & & & & & & & 31. Nannoceratopsis pellucida \\
\hline & $*$ & & & & & & & & & & $*$ & & & & & & & & $*$ & & & & * & * & & & & 32. Circulodinium vermiculatum \\
\hline & * & & & & & & & * & & & * & & & & * & & & & * & & $*$ & & * & * & & & & 33. Exochosphaeridium muelleri \\
\hline & $*$ & $*$ & $*$ & $*$ & * & $*$ & $*$ & $*$ & & & $*$ & $*$ & * & & $*$ & $*$ & & * & $*$ & & $*$ & $*$ & $*$ & $*$ & & & & 34. Scriniodinium campanula \\
\hline & $*$ & & & $*$ & & & $*$ & $*$ & & & & & $*$ & & & & & $*$ & $*$ & & & $*$ & $*$ & & $*$ & & $*$ & 35. Hystrichodinium voigtii \\
\hline & $*$ & $*$ & $*$ & & & $*$ & $*$ & & $*$ & & & $*$ & $*$ & $*$ & & & * & & & $* *$ & $*$ & $*$ & $*$ & $*$ & $*$ & $*$ & $*$ & 36. Nannoceratopsis gracilis \\
\hline & $*$ & & & & & & & & & & & & & & & & & & & & & & & & & & * & 37. Tanyosphaeridium magneticum \\
\hline & $*$ & & $*$ & $*$ & $*$ & $*$ & $*$ & $*$ & $*$ & * & $*$ & $*$ & $*$ & $*$ & * & $*$ & $*$ & $*$ & & & $*$ & & $*$ & $*$ & & $*$ & $* *$ & 38. Circulodinium distinctum \\
\hline & & $*$ & $*$ & $*$ & & $*$ & & $*$ & & * & & & $*$ & $*$ & $*$ & $*$ & $*$ & & & & & & & $*$ & & & & 39. Diacanthum hollisteri \\
\hline & & & $*$ & $*$ & $*$ & & & & $*$ & $*$ & $*$ & $*$ & * & $*$ & & $*$ & & & $*$ & & & & & & & & & 40. Amphorula metaelliptica \\
\hline & & & $*$ & & & & & & & & $*$ & & $*$ & & & & $*$ & & & & & & & & & & & 41. Kleithriasphaeridium fasciatum \\
\hline & & & $*$ & $*$ & $*$ & $*$ & $*$ & & & $*$ & $*$ & $*$ & $*$ & $*$ & & $*$ & $*$ & * & & & $*$ & $*$ & $* *$ & $* *$ & $*$ & $* *$ & $*$ & 42. Phoberocysta neocomica \\
\hline & & & * & & & $*$ & & & $*$ & $*$ & & $*$ & $*$ & $*$ & & $*$ & * & & & $* *$ & $*$ & & & & & $*$ & * & 43. Tanyosphaeridium isocalamum \\
\hline
\end{tabular}


Table 1. continued

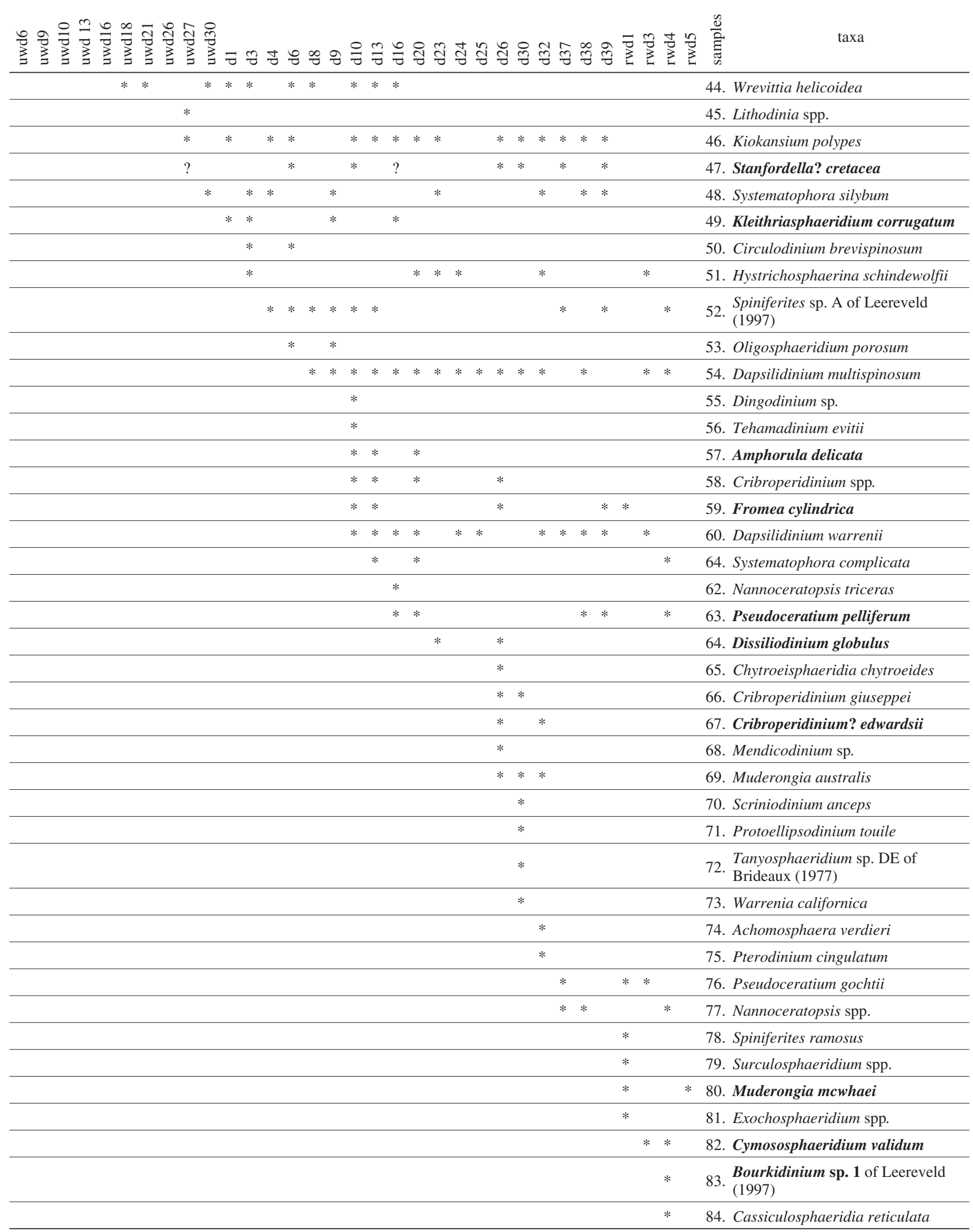


uppermost part of the documented section (Early Valanginian), i.e., the thickness on the level of approximately 185 to $190 \mathrm{~m}$ (related to the beginning of the main section).

Subfamily Olcostephaninae Haug, 1910

Type species. - Ammonites astierianus d'Orbigny, 1840.

\section{Genus Olcostephanus Neumayr, 1875}

\section{Olcostephanus balestrai (Rodighiero, 1919) Figure 10K}

1919 Astieria Balestrai Rod.; Rodighiero, p. 84, pl. 9, fig. 10, non fig. 13 .

2005 Olcostephanus balestrai (Rodighiero). - Klein, p. 82 (cum syn.).

Material. - Two fragments and one heavily deformed sculpture mould with the preserved incomplete last whorl (spec. GBA 2009/007/3). The umbilicus is filled with sediment.

Description. - With regard to the specific deformation of the shell, the section of whorls is unknown. The specimens bear dense, straight to slightly S-shaped, somewhat proverse ribs. The ribs come single, but primarily in pairs from small conical umbilical tubercles. Between the ribs connected with the tubercles, single ribs may be inserted. The majority of the ribs bifurcate at approximately below half of the deformed whorl height; sporadically inserted ribs of the same length occur. The ribbing is ended with a considerably inclined constriction indicating the vicinity of the mouth.

Measurements. - The considerably deformed specimen has a maximum diameter of approximately $34 \mathrm{~mm}$. At $\mathrm{D}=$ $29.8 \mathrm{~mm}$ (roughly along the axis of shortening), $\mathrm{H}=10.2$ (0.35), and $U=9.5$ (0.32). Per half a whorl, 9 tubercles fall on the periphery, 45 ribs correspond to the same part.

Remarks. - Punctate umbilical tubercles, dense and even ribbing caused especially by frequent rib bifurcation at the lower half of the whorl height and the wide umbilicus are specific features of the small specimen. The given features appear to be closest to microconchs of $O$. balestrai.

Distribution. - O. balestrai is known from Italy, France, Spain and recently from the Eastern Alps (Schrambach Formation in the Reichraming Nappe - Vašíček \& Faupl 2000) and from Morocco. According to the present ammonite zonation in the Mediterranean area, $O$. balestrai occurs in the Late Valanginian in the Neocomites peregrinus Zone.

Occurrence. - The specimen best preserved comes from the fossiliferous horizon Ross 2, $2.5 \mathrm{~m}$ above the base of the section in the Rossfeld Formation exposed below the upper waterfall (Late Valanginian).

\section{Genus Valanginites Kilian, 1910}

Type species. - Ammonites nucleus Roemer, 1841.

\section{Valanginites nucleus (Roemer, 1841)}

Figure $10 \mathrm{H}$

1841 Ammonites nucleus Phillips (?); Roemer, p. 87, pl. 13, figs $2 \mathrm{a}$, b.

2005 Valanginites nucleus (Roemer). - Klein, p. 109 (cum syn.).

Material. - A sculpture mould; the last and half of the last but one whorl are heavily crushed, rather asymmetrically into the bedding plane (spec. GBA 2009/007/4).

Description. - A semiinvolute, possibly complete specimen. Because of deformation, the section of whorls is unclear; it could be lenticular, but it is rather a round outer side masked by deformation. The largest width of the whorl may be found at the level of the umbilical tubercles. The sides of the last whorl are gently convex, and the umbilical wall is low. The umbilicus is fairly wide, which is, however, caused by the specific deformation of the final part of the last whorl.

Figure 8. Dinoflagellate cysts. The species name is followed by the sample location. Scale: $20 \mu m$. • A - Spiniferites sp. A of Leereveld (1997). Sample "D4". Schrambach Formation. • B - Achomosphaera neptunii (Eisenack, 1958) Davey \& Williams, 1966. Sample "rw1". Rossfeld Formation. - C - Prolixosphaenidium sp. A of Monteil (1993). Sample "D20". Schrambach Formation. • D, H - Amphorula delicata van Helden, 1986. Sample "D13". Schrambach Formation. • E - Hystrichodinium voigtii Alberti, 1961. Sample D20. Schrambach Formation. • F - Systematophora complicata Nale \& Sarjeant, 1962. Sample "D20". Schrambach Formation. • G - Pseudoceratium pelliferum Gocht, 1957. Sample "D20". Schrambach Formation. - I, J - Cribroperidinium sp. Sample "D13". Schrambach Formation. • K, N - Stanfordella ?cretacea (Nale \& Sarjeant, 1962) Helenes \& Lucas-Clark, 1997. Sample "D26". Schrambach Formation. • L - Hystrichosphaerina schindewolfii Alberti, 1961. Sample "D24". Schrambach Formation. - M - Systematophora scoriacea (Raynaud, 1978) Monteil, 1992. Sample "D25". Schrambach Formation. • O - Systematophora cf. areolata Klement, 1960. Sample "D25". Schrambach Formation. • P - Phoberocysta tabulata Raynaud, 1978. Sample D24. Schrambach Formation. • Q - Dapsilidinium warrenii (Habib, 1976) Lentin \& Williams, 1981. Sample "D24”. Schrambach Formation. 
Daniela Boorová et al. • Biostratigraphy of the Lower Cretaceous Schrambach Formation
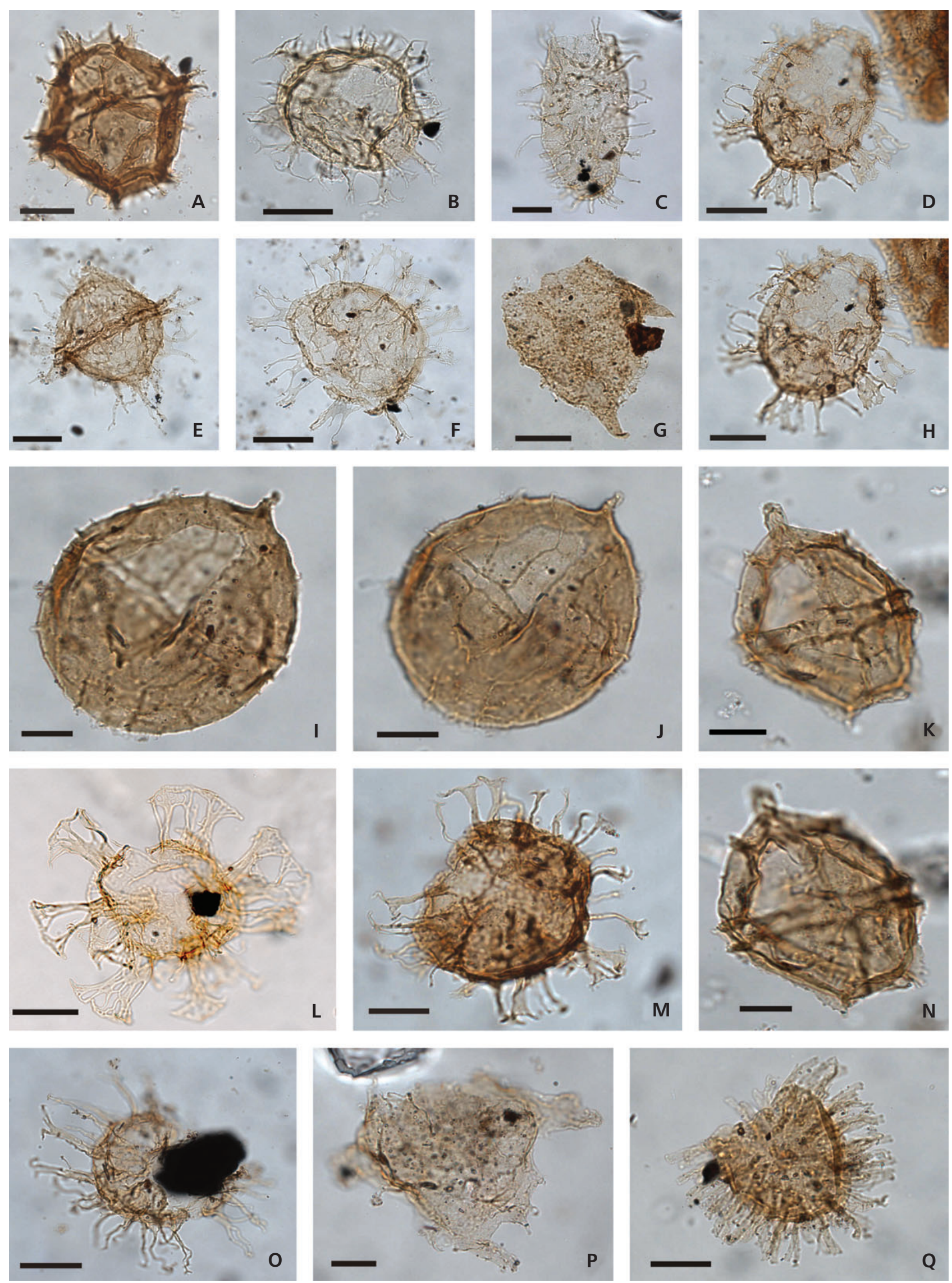
Primary ribs and the secondary ribs running from them are retroverse. On the penultimate whorl, at the beginning of the preserved sculpture, thin primary ribs appear near the coiling line. Rather high above the coiling line, these ribs strengthen into bullate tubercles. At the beginning of the last whorl, 2 and, in one case 3, ribs run from the tubercles towards the venter. On the next part of the last whorl, the ribs running from the tubercles become unclear; this could indicate the beginning of the living chamber. Between the tubercles, typically there are only simple and unclear interribs. Certain interribs reach as far as the line of coiling. On the opposite side of the specimen, in a narrow zone on the shell periphery in the final fourth part of it, dense, retroverse, uniform ribs are visible. At the end of the shell, in the area of a presupposed mouth, ribs straighten on the sides, and in its final part, an incompletely preserved constriction is indicated.

Measurements. - The heavily deformed shell has a diameter of 39.5-40 mm. At the deformed diameter, $\mathrm{D}=35.00 \mathrm{~mm}$, $\mathrm{H}=13.2 \mathrm{~mm}(0.38)$ and $\mathrm{U}=9.9$ (0.28). On the last whorl, 17 tubercles are near the umbilicus.

Remarks. - Because of the strong deformation of the specimen, it was extremely difficult to decide on the generic assignation. According to the shape of the shell and ribbing, 3 genera were considered: Olcostephanus Neumayr, 1875, Dichotomites Koenen, 1909 and Valanginites Kilian, 1910. Initially, the width of the umbilicus and ribbing on the periphery of the visible side of the specimen are confusing features.

However, inside of the umbilicus, after removal of the sediment, a dense coiling line corresponding to the deep funnel-shaped umbilicus of the involute coiled specimen can be observed. In the narrow part of the nearly nonpreserved opposite side of the shell, it is possible to observe that the ribs in the ventral area are not so sparse, as indicated by the ribbing on the visible side of the last whorl, but they are denser and multiplied. Based on the presented information, we assign the Alpine specimen to Valanginites, to $V$. nucleus, in accordance with the majority of specimens and data of Ploch (2003).

Distribution. - According to the concept of Ploch (2003), $V$. nucleus has a considerable geographical distribution. $V$. nucleus is known from Boreal localities in Germany, Poland, and others and from Mediterranean deposits in Europe, and from Morocco. In accordance with the present concept of the Mediterranean ammonite zones, $V$. nucleus occurs in the Late Valanginian, in the lower part of the Neocomites peregrinus Zone.

Occurrence. - The only specimen was found in the Rossfeld Formation from the fossil-bearing horizon Ross 2 (Late Valanginian) located $2.5 \mathrm{~m}$ above the base of the section below the upper waterfall.

\section{Valanginites bachelardi (Sayn, 1889)}

Figure 9G

1889 Holcostephanus Bachelardi sp. nov.; Sayn, p. 679, pl. 17 , figs $1 \mathrm{a}, \mathrm{b}$.

2005 Valanginites bachelardi (Sayn). - Klein, p. 108 (cum syn.).

Material. - A single sculpture mold, with a planar strong compaction, with a corroded sculpture around the umbilicus (spec. GBA 2009/007/5).

Description. - Microconch of an originally spheroidal specimen, now flat, involuted with a narrow umbilicus. The sides of the ultimate whorl are covered with thin and dense, equally strong ribs that are preserved best on the external half of the whorl. In the lower part of the whorl, ribs bifurcate; this is barely visible because of the corrosion of the umbilical area. In addition to the thin ribs, two thin constrictions are present, slightly concave toward the mouth. One of the constrictions occurs most likely at the end of the phragmocone and the other at the end of the specimen. The

Figure 9. Cephalopods. • A - Erdenella paquieri (Simionescu), spec. GBA 2009/007/8. Schrambach Formation, outcrop in the bottom of the stream on the level of $165 \mathrm{~m}$, corresponding to the level of $123 \mathrm{~m}$ in the thickness of the section. Late Berriasian. • B - Berriasella sp., incomplete shell of spec. GBA 2009/007/7. Schrambach Formation, debris on the level of about $176 \mathrm{~m}$ (corresponding to the level of about $127 \mathrm{~m}$ in the thickness of the section). ?Late Berriasian. $\bullet$ C - Berriasella cf. calisto (d'Orbigny), spec. GBA 2009/007/6. Schrambach Formation, debris on the level of $255 \mathrm{~m}$ (corresponding to the level of $141 \mathrm{~m}$ in the thickness of the section). Late Berriasian. $・$ D, E - Schrambachoceras weidichi sp. nov.; holotype, spec. GBA 2009/007/15; D - ×2, $\mathrm{E}-\times 1$. Schrambach Formation, outcrop in the bottom of the stream on the level of $402 \mathrm{~m}$, corresponding to the level of $180 \mathrm{~m}$ in the thickness of the section. Berriasian/Valanginian boundary. $\bullet F-$ Leptoceras brunneri (Ooster), spec. GBA 2009/007/16. Schrambach Formation, outcrop in the bottom of the stream on the level of $340 \mathrm{~m}$, corresponding to the level of $169.5 \mathrm{~m}$ in the thickness of section. Late Berriasian. $\bullet \mathrm{G}-$ Valanginites bachelardi (Sayn), deformed spec. GBA 2009/007/5. Debris in the bottom of the stream on the level of $343 \mathrm{~m}$ (about $170 \mathrm{~m}$ of the thickness). ?Late Valanginian. - H - Mortilletilamellaptychus cf. stanislavi Měchová, Vašíček \& Houša, spec. GBA 2009/007/19. Schrambach Formation, $160 \mathrm{~m}$ from the beginning of the section, on the level of about $122 \mathrm{~m}$ in the thickness of the section. Late Berriasian. • I - Mortilletilamellaptychus cf. elegans (Renz), spec. GBA 2009/007/20. Schrambach Formation, on the level of $368 \mathrm{~m}$, approximately on the level of about $178 \mathrm{~m}$ in the thickness of the section. ?Late Berriasian. Scale bar $1 \mathrm{~cm}$. 


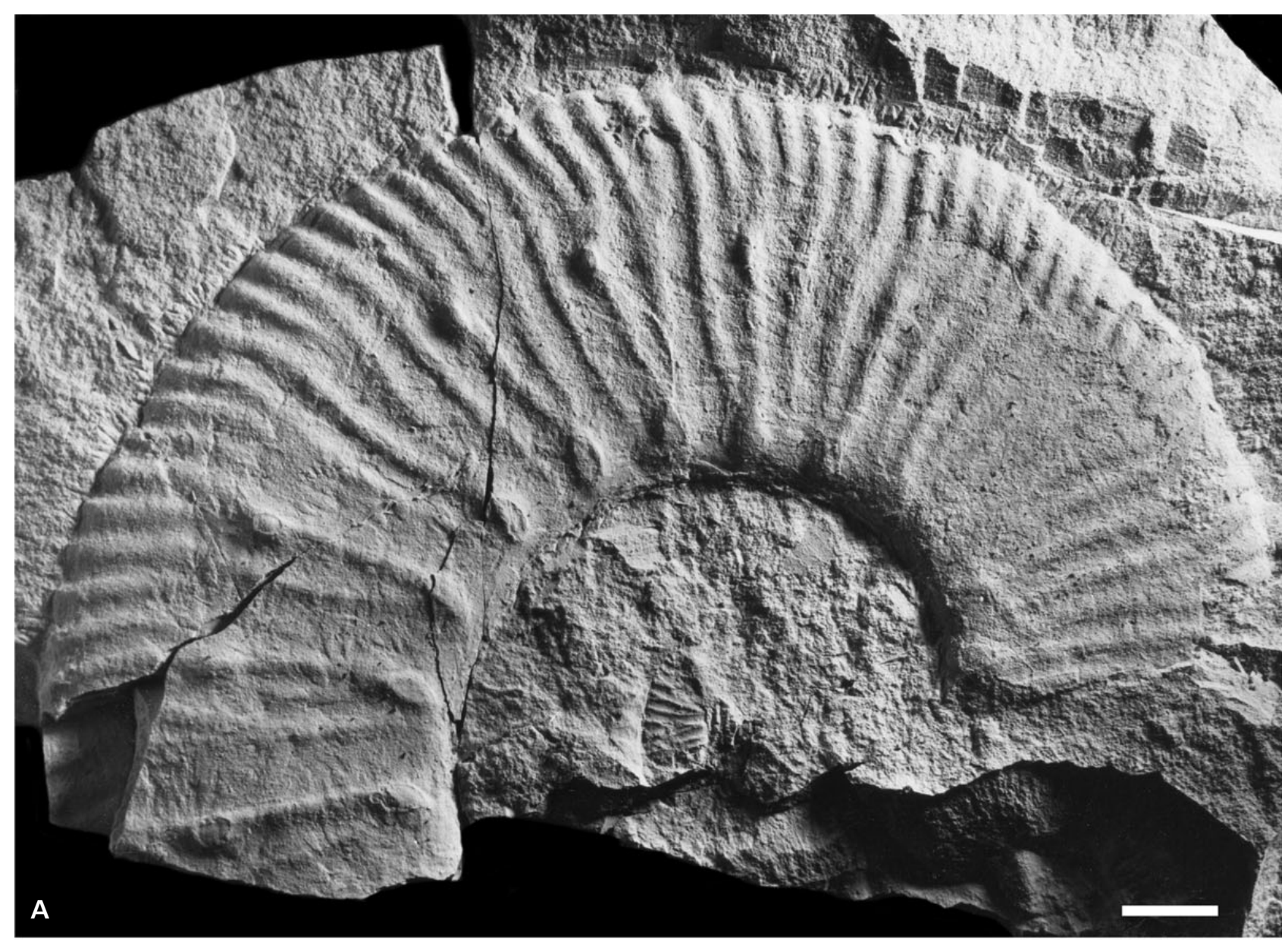

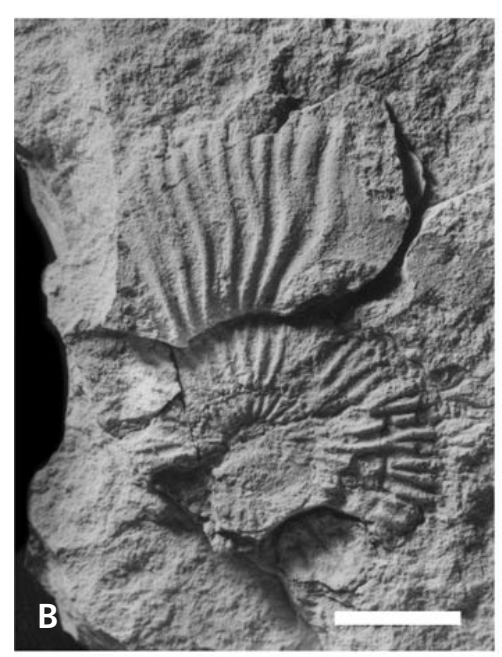

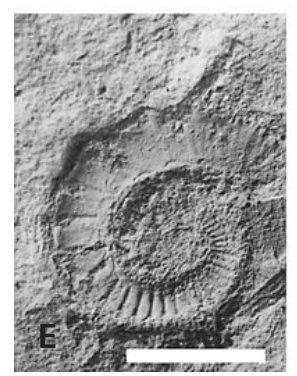

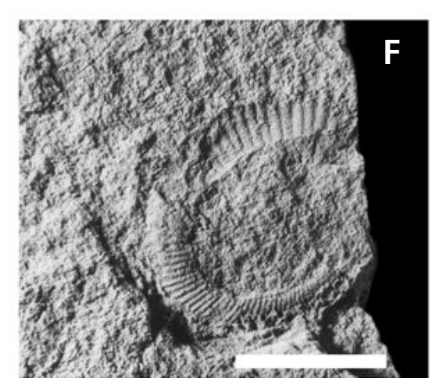
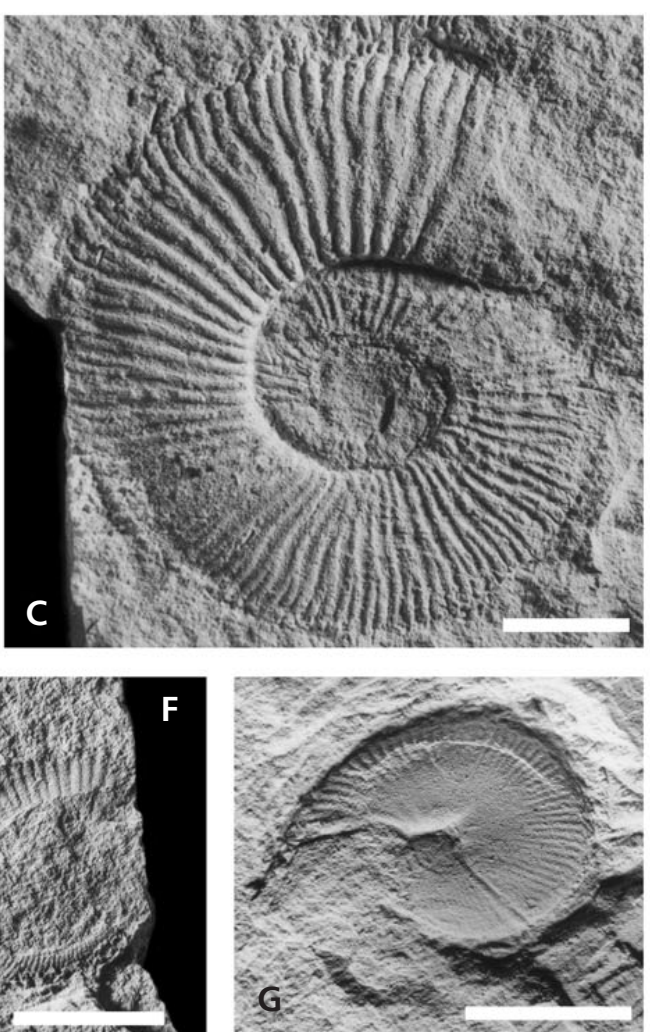
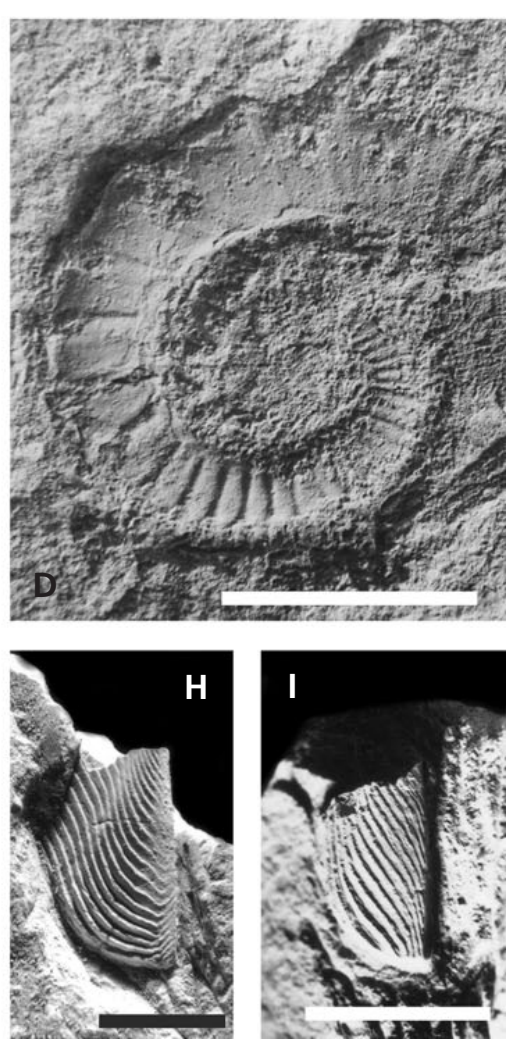
specimen reaches maximally approximately $18 \mathrm{~mm}$ in diameter.

Remarks. - Ploch (2003) considers V. bachelardi, which belongs to the category of microconchs, a synonym of $V$. nucleus (Roemer). With regard to the dense and thin ribbing of the Alpine specimen, which is specific in sculpture, we adhere to the designation $V$. bachelardi. The Alpine specimen is very close to the shell that is illustrated by Faraoni et al. (1997, pl. 6, fig. 1).

Distribution. - According to recent data in the literature (e.g. Faraoni et al. 1997) and the present-day ammonite zonation of the Lower Cretaceous (Reboulet et al. 2011), $V$. bachelardi occurs in the Late Valanginian in the ammonite Neocomites peregrinus Zone. The species is cosmopolitan, and is known from subboreal deposits in Poland and from the Mediterranean area from France, Spain, Italy, Romania and from the Czech and Slovak Western Carpathians.

Occurrence. - The specimen was found redeposited in debris in the bottom of the creek at the $170 \mathrm{~m}$ thickness.

Family Neocomitidae Salfeld, 1921

Subfamily Berriasellinae Spath, 1922

\section{Genus Berriasella Uhlig, 1905}

Type species. - Ammonites privasensis Pictet, 1867.

The emended characteristics of the genus Berriasella are stated by Arkadiev \& Bogdanova (2004, 2012). The previous concept of division of the genus Berriasella into subgenera (e.g. Tavera Benitez, 1985) is abandoned those studies; we accept this conception.

\section{Berriasella cf. calisto (d'Orbigny, 1850)}

Figure 9C

1987 Berriasella calisto (d'Orbigny). - Company, p. 104, pl. 3, figs 9-11; pl. 18, fig. 4 (cum syn.).

2000 Berriasella (Berriasella) calisto (d'Orbigny). - Vašíček et al., p. 632, pl. 3, fig. 3 .

2005 Berriasella (Berriasella) calisto (Orbigny). - Klein, p. 166 (cum syn.).

2012 Berriasella callisto (d'Orbigny). - Arkadiev \& Bogdanova, p. 148, pl. 4, figs 7, 8 (cum syn.).

2013 Berriasella (Berriasella) calisto (d'Orbigny). - Bujtor et al., p. 283, fig. 5A.

Material. - The only well preserved sculpture mould was heavily squeezed to the plane of bedding (spec. GBA 2009/007/6).

Description. - A half-involute specimen with a rather wide umbilicus and with an approximately even height of whorls. Ribs begin in singles at the umbilicus. Exceptionally, two ribs run together from the umbilicus on the phragmocone. At approximately half the height of the whorl, the prevailing majority of the ribs bifurcate so that only a few of them remain simple.

Measurements. - At D = $56.6 \mathrm{~mm}, \mathrm{H}=20.9$ (0.37) and $\mathrm{U}=20.6$ (0.36). At the maximum diameter of approximately $58 \mathrm{~mm}, 26$ ribs fall per half-whorl at the umbilicus, and 55 ribs fall per half-whorl around the periphery.

Figure 10. Cephalopods. • A - Thurmanniceras otopeta Thieuloy, spec. GBA 2009/007/10. Folded upper part of the section, Schrambach Formation, debris in the bottom of the stream between 360 and 400 m (about 178 m). Late Berriasian. • B - Spiticeras cf. correardi Djanélidzé, spec. GBA 2009/007/2. Upper part of the Schrambach Formation, debris in the slope in the overlay of the last accessible outcrop of the mentioned formation on the level of $414 \mathrm{~m}$, corresponding to the level of about $190 \mathrm{~m}$ in the total thickness of documented section. Early Valanginian. • C - Thorolamellaptychus trauthi (Renz \& Habicht), spec. GBA 2009/007/23. Schrambach Formation, outcrop at $274 \mathrm{~m}$, corresponding to the level of $143.5 \mathrm{~m}$ in the thickness of the section. $\bullet$ D - Thurmanniceras pertransiens (Sayn), $\times 1$; spec. GBA 2009/007/11. Schrambach Formation, debris in the stream on the level of $360 \mathrm{~m}$ (about $178 \mathrm{~m}$ in thickness). Early Valanginian. $\bullet$ E - Tirnovella alpillensis (Mazenot), spec. GBA 2009/007/9. Schrambach Formation, outcrop on the level of $340 \mathrm{~m}$, corresponding to the level of $169.5 \mathrm{~m}$ in the thickness of the section. Late Berriasian. $\bullet \mathrm{F}$, G - Protancyloceras punicum Arnould-Saget; F - spec. GBA 2009/007/13. Schrambach Formation, debris in the stream on the level of about 386 m. Late Berriasian; G - spec. GBA 2009/007/14. Schrambach Formation, debris in the stream on the level of $386 \mathrm{~m}$ (about $179 \mathrm{~m}$ ). Late Berriasian. $\bullet \mathrm{H}-$ Valanginites nucleus (Roemer), strongly deformed spec. GBA 2009/007/4. Rossfeld Formation, faunistic horizon Ross 2, $2.5 \mathrm{~m}$ in the overburden above the beginning of outcrops in the given formation. Late Valanginian. • I - Thorolamellaptychus bermudensis (Renz), spec. GBA 2009/007/21. Schrambach Formation. Debris in the uppermost accessible part of Schrambach Formation on the level of $414 \mathrm{~m}$ (about $183 \mathrm{~m}$ ). ?Early Valanginian. $\bullet \mathrm{J}-$ Neocomites neocomiensis (d'Orbigny), impression, spec. GBA 2009/007/24. Rossfeld Formation, debris below the Rossfeld waterfall. Late Valanginian. - K - Olcostephanus balestrai (Rodighiero), spec. GBA 2009/007/3. Rossfeld Formation, faunistic horizon Ross 2 , $2.5 \mathrm{~m}$ thickness above the beginning of outcrops of the given formation. Late Valanginian. $\bullet$ L - Thorolamellaptychus symphysocostatus (Trauth), spec. GBA 2009/007/22. Rossfeld Formation, debris below the Rossfeld waterfall. Valve lying on the same bedding plane with Neocomites neocomiensis. Late Valanginian. Scale bar $1 \mathrm{~cm}$.

Photographs taken by K. Mezihoráková, Ostrava. All material was whitened with ammonium chloride before taking the photos. Aptychi in photoplates are orientated according to expected life positions. All specimens with inventory numbers from the locality of Schrambachgraben will be deposited in the collections of the Geological Survey of Austria in Vienna. 
Daniela Boorová et al. • Biostratigraphy of the Lower Cretaceous Schrambach Formation
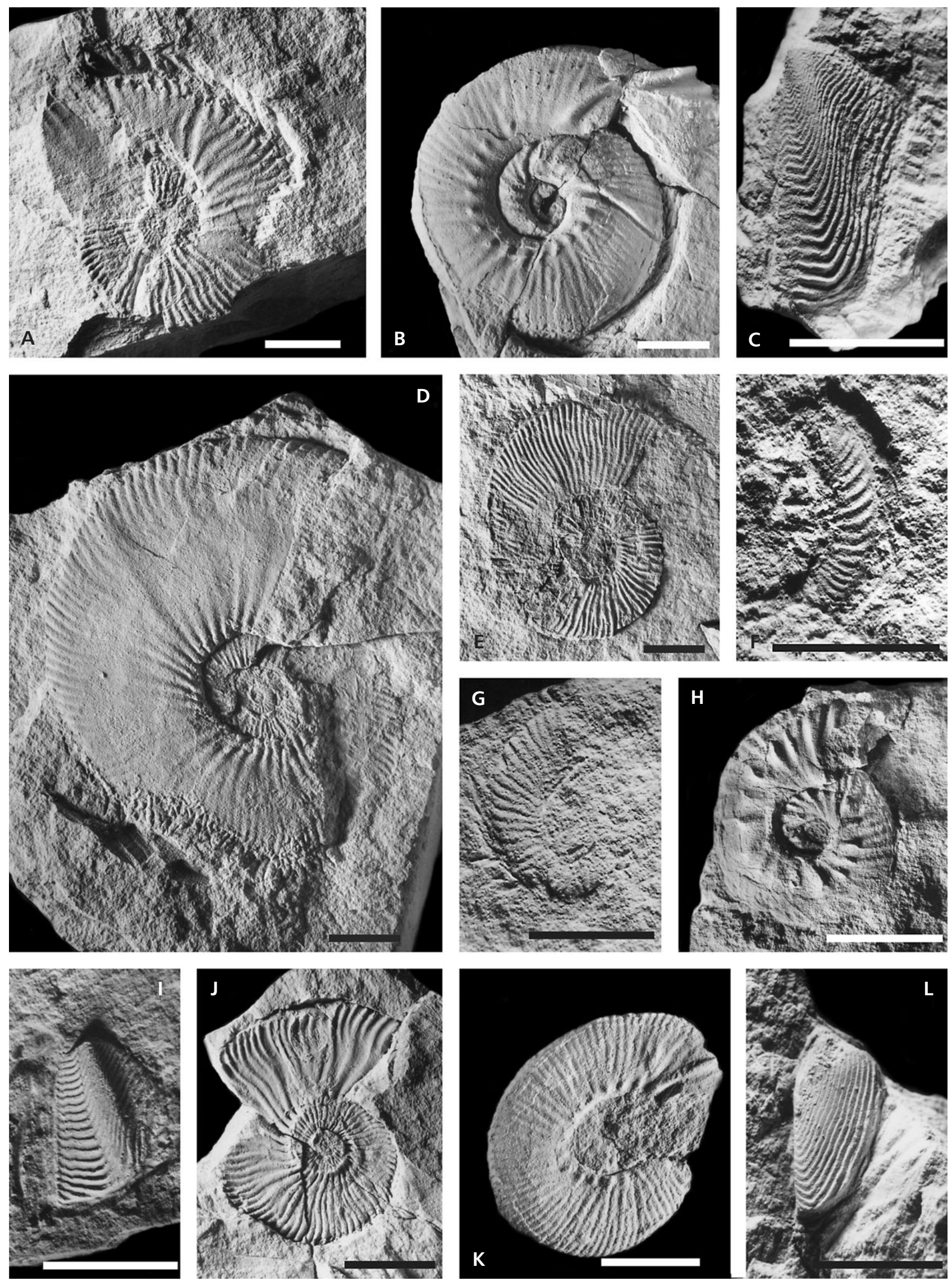
Remarks. - The height of the whorl is slightly higher than the width of the umbilicus. The species determination is not certain because it is not clear whether ribs on the ventral side are interrupted, the ribs are not more S-shaped and the phragmocone appears to be more densely ribbed than usual.

Distribution. - According to the newest data from the literature (e.g., Bujtor et al. 2013), B. calisto is known from the Late Berriasian (Subthurmannia boissieri Zone, Thurmanniceras otopeta Subzone) of the Mediterranean area.

Occurrence. - Debris of the Schrambach Formation in the area of the zone of outcrops in the stream approximately $255 \mathrm{~m}$ away from the upper edge of the lower waterfall, approximately at the $141 \mathrm{~m}$ level of the section.

\section{Berriasella sp.}

Figure 9B

Material. - The only quite imperfectly preserved sculpture mould that ends in an unclear jugal apophysis (spec. GBA 2009/007/7).

Description. - A microconch with rather evolute coiling. The ribbing on preserved whorls represents the alternation of simple ribs and bifurcated ribs. The bifurcation of the ribs occurs only at approximately half the height of the deformed whorl. The preservation of the external side makes it impossible to elucidate whether the ribs pass to the external side continuously or whether they are interrupted.

Measurements. - The maximum diameter of the shell reaches approximately $55 \mathrm{~mm}$. At $\mathrm{D}=50 \mathrm{~mm}, \mathrm{H}$ is approximately $18.5(0.37)$ and $U$ is $21.0(0.42)$. At the shell diameter of approximately $30 \mathrm{~mm}, 18$ ribs at the umbilicus fall per half-whorl.

Remarks. - The unfavourable preservation does not allow any determination closer than the genus. The absence of polygyrate ribs and the total morphology correspond to primitive berriasellids. In the case of a developed siphonal furrow, the specimen could belong to the group Berriasella picteti (Jacob in Kilian, 1910). If no furrow is developed, then it could belong to the group Berriasella jauberti (Mazenot, 1939).

Occurrence. - Debris of the Schrambach Formation at the approximate level of $127 \mathrm{~m}$ of thickness in the section, above the upper edge of the lower waterfall. A Late Berriasian age can be concluded.
Subfamily Neocomitinae Salfeld, 1921

\section{Genus Erdenella Nikolov, 1979}

Type species. - Hoplites Paquieri Simionescu, 1899.

\section{Erdenella paquieri (Simionescu, 1899)}

Figure 9A

1899 Hoplites Paquieri fam. nov.; Simionescu, p. 7, pl. 1, figs $6 a, b$.

1982 Jabronella (Erdenella) paquieri Simionescu. - Nikolov, p. 190, pl. 58, figs 2 (refiguration of holotype), 3; pl. 59, fig. 2.

1987 Jabronella paquieri (Simionescu). - Company, p. 110 , pl. 4 , figs 4,5 ; pl. 18 , fig. 8 .

2005 Erdenella paquieri (Simionescu). - Klein, p. 246 (cum syn.).

Material. - Two large sculpture moulds squeezed to the plane of bedding. The better-preserved specimen represents merely an adult half-whorl that most likely predominantly belongs to the body chamber (spec. GBA 2009/007/8).

Description. - A large half-evolute specimen with medium-high whorls. The preserved half-whorl bears rather sparse, slightly S-shaped ribs. The ribs run in pairs from the umbilical bullae. Some of the ribs remain simple; most of them, however, bifurcate at approximately $2 / 3$ of the height of the whorl. The bifurcation of many ribs, especially at the end of the preserved whorl, is accompanied by lateral tubercles. Three ribs run sporadically from the lateral tubercles. The third rib also can have the character of a short inserted rib. The other bifurcations are not accompanied by any tubercles. Between the paired ribs, simple ribs may be inserted in singles as far as the level of the umbilical tubercles. Around its periphery, each rib bears indicated marginal tubercles, behind which most likely a narrow zone of rib weakening or even a narrow furrow occurs. At the end of the preserved whorl, in contrast to the previous part, the ribs become sparser.

Measurements. - The maximum diameter of the betterpreserved specimen is approximately $170 \mathrm{~mm} . \mathrm{H}$ is approximately $58 \mathrm{~mm}(0.34)$ and $\mathrm{U}$ is approximately $67 \mathrm{~mm}$ (0.39). Per half-whorl, 11 umbilical tubercles fall, which corresponds to approximately 53 ribs around the venter.

Remarks. - The lateral tubercles begin to appear most likely only at the end of the phragmocone. The rather sparse ribbing observable in the small section of the juvenile whorl lead us to assign the finding to Erdenella. According to 
Klein (2005), we consider this specimen to be an individual genus and not a synonym of Subalpinites Mazenot, 1939 (see Wright et al. 1996) or a subgenus of the Jabronella Nikolov, 1966.

Distribution. - Erdenella paquieri is known from the Late Berriasian (Subthurmannia boissieri ammonite Zone) from France, Italy, Spain, Algeria, Morocco, Romania, Bulgaria, Georgia, North Caucasus, etc.

Occurrence. - The outcrop in the Schrambach Formation in the bed of creek above the upper edge of the lower waterfall, which corresponds to the level of approximately $123 \mathrm{~m}$ thickness of the section.

\section{Genus Tirnovella Nikolov, 1966}

Type species. - Berriasella alpillensis Mazenot, 1939.

\section{Tirnovella alpillensis (Mazenot, 1939)}

Figure 10E

1939 Berriasella alpillensis sp. nov.; Mazenot, p. 73, pl. 6, figs $22 \mathrm{a}-\mathrm{c}$.

2005 Tirnovella alpillensis (Mazenot). - Klein, p. 254 (cum syn.).

2012 Tirnovella alpillensis (Mazenot). - Arkadiev \& Bogdanova, p. 158, pl. 7, fig. 10 (cum syn.).

Material. - The only heavily deformed sculpture mould (spec. GBA 2009/007/9).

Description. - A semi-evolute specimen, because of the deformation of the unknown whorl section. The sculpture of the phragmocone differs somewhat from that of the body chamber. Ribs on the phragmocone typically run in pairs from the umbilical tubercles or are inserted singly between paired ribs and do not begin in the tubercles. The majority of ribs bifurcate at varying heights of the whorl. In two or three cases, constrictions are indicated on the phragmocone. On the body chamber, to which the final half of the ultimate whorl most likely belongs, ribs are denser than on the phragmocone. The ribs are slightly $\mathrm{S}$-shaped and run single or in pairs. Due to the imperfect preservation of the umbilical region, no umbilical tubercles are evident. Most of the ribs bifurcate on the sides of the whorl at varying heights. Ribs do not exceed the ventral side because, in the siphonal area, there is a narrow smooth zone.

Measurements. - At $\mathrm{D}=59.2 \mathrm{~mm}$ (maximum diameter by the strong deformation), $\mathrm{H}=23.8(0.40)$ and $\mathrm{U}=21.0$ (0.35).
Remarks. - The Alpine specimen is similar by rather sparse ribs on the phragmocone to the shell illustrated in Tavera Benitez (1985, pl. 45, fig. 3). The ribbing of the body chamber corresponds to typical representatives of the species.

Distribution. - According to data in the literature, this index species occurs in the uppermost Berriasian, in the Subthurmannia boissieri Zone, Tirnovella alpillensis and Thurmanniceras otopeta subzones. This species is known from France, Spain, Italy, Bulgaria, the Eastern Alps (Lechtal Nappe), Bulgaria, Crimea, Georgia, Morocco and Iraq.

Occurrence. - An outcrop in the stream channel in the Schrambach Formation corresponding to 169.5 m of thickness in the section.

\section{Genus Thurmanniceras Cossmann, 1901}

Type species. - Ammonites thurmanni Pictet \& Campiche, 1860.

\section{Thurmanniceras otopeta Thieuloy, 1979}

Figure 10A

1979 Thurmanniceras otopeta sp. nov.; Thieuloy, p. 37, pl. 1, figs $1-4$.

2005 Thurmanniceras otopeta Thieuloy. - Klein, p. 278 (cum syn.).

Material. - An imperfectly preserved, incomplete, deformed sculpture mould corroded on the circumference of the shell, with a poorly preserved umbilical area. According to indistinct last sutures, the final half of the ultimate whorl belongs to the living chamber (spec. GBA 2009/007/10).

Description. - Semi-involute specimen, with slightly vaulted whorls. Falcoid ribs run in singles or in pairs from umbilical tubercles. The majority of ribs bifurcate at approximately the mid-flank whorl. On the living chamber, relatively wide, shallow constrictions are evident. On the end part of the shell, the rib weakening on the flanks is indistinct. The maximum diameter is approximately $44 \mathrm{~mm}$.

Distribution. - Thurmanniceras otopeta is a subzone species in the uppermost part of the Late Berriasian Subthurmannia boissieri ammonite Zone in the Mediterranean area.

Occurrence. - The Schrambach Formation, debris at the level of approximately $178 \mathrm{~m}$ in the thickness of the section. 


\section{Thurmanniceras pertransiens (Sayn, 1907)} Figure 10D

1907 Thurmannia pertransiens sp. nov.; Sayn, p. 43, pl. 8, fig. 14 ; pl. 9, figs $10,15,17$, text-fig. 18 .

2005 Thurmanniceras pertransiens (Sayn). - Klein, p. 279 (cum syn.).

Material. - One incompletely preserved, deformed sculpture mould with a counter-impression, with a partially corroded periphery in places (spec. GBA 2009/007/11) and another fragment (spec. GBA 2009/007/12).

Description. - Macroconchs with a rather narrow umbilicus and high whorls. On the juvenile whorls, slight constrictions are visible. On the last whorl, the dense ribs begin in the umbilical tubercles. On the sides of the whorl, the sculpture is weakened considerably.

Measurements. - Spec. 2009/007/11 has the diameter D = $72 \mathrm{~mm}$ (close to the maximum diameter), $\mathrm{H}=33.1(0.46)$ and $\mathrm{U}=19.0(0.26)$.

Distribution. - Thurmanniceras pertransiens is a zone species of the Early Valanginian in the Mediterranean area.

Occurrence. - The Schrambach Formation, the folded upper part of section, debris situated on the level of $178 \mathrm{~m}$ and approximately $180 \mathrm{~m}$.

Suborder Ancyloceratina Wiedmann, 1966 Superfamily Protancyloceratoidea Breistroffer, 1947 Family Protancyloceratidae Breistroffer, 1947

\section{Genus Protancyloceras Spath, 1924}

Type species. - Ancyloceras Guembeli Oppel in Zittel, 1870.

\section{Protancyloceras punicum Arnould-Saget, 1953} Figure 10F, G

1953 Protancyloceras punicum sp. nov.; Arnould-Saget, p. 114, pl. 11, figs $1-3$.

2003 Protancyloceras punicum Arnould-Saget. - Vašíček \& Hoedemaeker, p. 13, pl. 1, figs 1, 2 (cum syn.).

Material. - Two deformed small fragments preserved as sculpture moulds (GBA 2009/007/13 and 2009/007/14).

Description. - Specimens are small and loosely coiled. Flanks of the shells bear relatively dense, simple, slightly S-shaped ribs. A narrow zone on the periphery of the venter is smooth. The maximum diameter of the incomplete shell of the larger fragment (2009/007/14) is $16 \mathrm{~mm}$; the height of the whorl is $5 \mathrm{~mm}$. The whorl height of the smaller specimen is merely $3 \mathrm{~mm}$.

Occurrence. - According to Vašíček \& Hoedemaeker (2003), P. punicum occurs from the Middle Berriasian (Subthurmannia occitanica Zone) to the Late Berriasian (Thurmanniceras otopeta Zone) and is known primarily from Tunisia, Spain, France and Italy.

Distribution. - The Schrambach Formation. The larger fragment (2009/007/14) was found in the outcrop on the level of $169.5 \mathrm{~m}$, and the smaller fragment comes from the debris on approximately the $179 \mathrm{~m}$ level.

\section{Genus Schrambachoceras gen. nov.}

Type species. - Protancyloceras obscurocostatum Vašíček \& Hoedemaeker, 2003.

Etymology. - According to the name of the Schrambach creek, in which the type section of the Schrambach Formation is exposed.

Diagnosis. - Small shells coiled in a developed crioceratid spiral. The initial whorls with simple dense ribs and adult ones with increasingly sparser to fading ribs that bear marginal tubercles. Suture of the protancyloceratid type.

Remarks. - The genus is related to Leptoceras Uhlig, 1883 and Protancyloceras Spath, 1924. Both the genera differ by the unweakened sculpture up to the adult stage. With the genus Leptoceras, no tubercles are developed.

The new genus content is the type species Schramabachoceras obscurocostatum and $S$. weidichi $\mathrm{sp}$. nov.

\section{Schrambachoceras weidichi sp. nov.} Figure 9D, E

2003 ?Leptoceras studeri (Ooster), morphotype sapunovi sensu Nikolov. - Vašíček \& Hoedemaeker, pl. 2, fig. 5 .

Holotype. - The shell designated by the above mentioned species name (spec. GBA 2009/007/15), illustrated here in Fig. 9D, E.

Etymology. - The species is named after Dr K.F. Weidich from Munich, who had studied the section previously, but especially from the microfaunistic perspective. 
Type horizon and locality. - Schrambach Formation, Early Valanginian, Schrambachgraben creek near Kuchl.

Diagnosis. - A small shell coiled in a loose spiral, with conspicuous simple ribs bearing marginal tubercles at the beginning. Gradually, the spaces between the ribs increase; the ribs fade out and the marginal tubercles remain.

Material. - The holotype preserved as a sculpture mould without any juvenile whorls. The siphonal area is not preserved. Another imperfectly preserved fragment of the whorl of the final part of the phragmocone (GBA 2009/007/25).

Description. - A small specimen coiled in a loose spiral with a low height of whorls. The most juvenile part bears dense, simple, prevailingly straight ribs, clearly inclined towards the mouth around the periphery. In the later stage, the simple ribs become sparse. In the vicinity of the ventral side, small marginal tubercles appear on the ribs, behind which the ribs most likely incline towards the mouth. After this stage with marked ribs, the final part with the weakened sculpture follows. The given section most likely belongs to the body chamber. Sparse, weakened main ribs can be observed here. The ribs are retroversal at the end with marginal tubercles. Between the ribs, thin, rather dense ribs are present.

Measurements. - The maximum diameter of the holotype reaches approximately $21 \mathrm{~mm}$. At $\mathrm{D}=19.2 \mathrm{~mm}, \mathrm{H}=0.6$ $(0.31)$ and $\mathrm{U}=10.0(0.52)$.

Remarks. - The new species somewhat reminds us of certain representatives of Leptoceras Uhlig, namely sparsely ribbed shells that Nikolov (1967) designated originally as Protoleptoceras jelevi sapunovi (= Leptoceras studeri Ooster, 1860). However, Schrambachoceras weidichi differs, especially by the developed tubercles. By the bend of the ribs in the tubercles, chevrons could be formed that are close to Protancyloceras Spath, 1924. Shells of the last mentioned genus may be coiled in a slightly to loosely coiled spiral up to vaulted shells. However, ribbing on the entire shell remains preserved.

A related species is Schrambachoceras obscurocostatum; however, its specimens are more robust. The juvenile ribbing stage ends earlier, and the main ribs are less conspicuous. The marginal tubercles in both ribs are roughly equally developed.

Distribution. - In addition to the type material, an imperfectly preserved specimen (impression) from the Río Argos section in Spain belongs to the species. This specimen comes from the basal Valanginian.
Occurrence. - Outcrop of the Schrambach Formation in the stream, which corresponds to the $180 \mathrm{~m}$ level in the main section (near the Berriasian/Valanginian boundary).

Family Leptoceratoididae Thieuloy, 1966 (nom. transl. Vermeulen 2005)

\section{Genus Leptoceras Uhlig, 1883}

Type species. - Ancyloceras Brunneri Ooster, 1860.

\section{Leptoceras brunneri (Ooster, 1860)}

Figure 9F

2000 Leptoceras studeri (Ooster). - Vašíček et al., pl. 4, fig. 4.

2003 Leptoceras brunneri (Ooster). - Vašíček \& Hoedemaeker, p. 18, pl. 2, fig. 6 (cum syn.).

2007 Leptoceras brunneri (Ooster). - Klein et al., p. 18 (cum syn.).

Material. - Four prevailingly fragmentary sculpture moulds representing both juvenile shells (spec. GBA 2009/007/16) and larger adult shells (spec. GBA 2009/007/17).

Description. - Rather large specimens with obviously developed whorls. The whorls are low. The juvenile whorls bear thin and dense prorsiradiate ribs. The adult ribs are more conspicuous, sparser, subradiate to slightly convex, arcuated towards the mouth.

Measurements. - The diameter of the larger shell reaches approximately $43 \mathrm{~mm}$.

Remarks. - L. brunneri differs from its relative Leptoceras studeri (Ooster), especially by the smaller height of the whorls and by the straight run of the ribs in the adult stage. The shell of $L$. studeri is coiled merely in a slightly developed spiral with whorls partially touching each other.

In addition to the type material, the adult Eastern Alpine shell is also very close to Company's specimen (1987, pl. 1, figs 7a, b) designated, however, as $L$. studeri.

Distribution. - L. brunneri is reported from the Late Berriasian from Switzerland, southeastern France, Spain, the Northern Calcareous Alps and most likely also from Romania.

Occurrence. - The specimens we found come from the outcrop in the section, which corresponds to the level of approximately $169.5 \mathrm{~m}$ of thickness in the section. Schrambach Formation, Late Berriasian. 


\section{Aptychi}

Aptychi are, in addition to the shells of ammonites, other specific parts of ammonites that occur in the Lower Cretaceous deposits in the Schrambachgraben section (Fig. 3). Their isolated ribbed calcite valves are typically preserved in fragmentary form. The valves are usually deformed, because the arch of the valves was often broken, and the valves were deformed onto the bedding plane.

Ribbed Lower Cretaceous aptychi were typically classified into an artificial genus, Lamellaptychus Trauth, 1927. Later, Lamellaptychus was divided by Turculet (1994) into subgenera. Only recently, a proposal for a new classification of ribbed Lower Cretaceous aptychi (Měchová et al. 2010) was submitted, respecting the basic ribbing and nomenclatoric rules. We follow this classification. In the cited paper, the terminology used in the description of the valves is presented.

Family Lamellaptychidae Měchová, Houša \& Vašíček, 2008

\section{Genus Mortilletilamellaptychus Měchová, Vašíček \& Houša, 2010}

Type species. - Aptychus Mortilleti Pictet \& Loriol, 1858.

\section{Mortilletilamellaptychus cf. stanislavi Měchová, Vašíček \& Houša, 2010 \\ Figure $9 \mathrm{H}$}

1985 Lamellaptychus aff. retroflexus Trauth. - Renz \& Habicht, pl. 2, figs 25, 26.

2010 Mortilletilamellaptychus stanislavi Měchová, Vašíček \& Houša; Měchová et al., p. 248, fig. 9L (cum syn.).

Material. - A single, incomplete valve without the apical area. The preserved part has the length equal to approximately $2 / 3$ the length of the complete valve (spec. GBA 2009/007/19).

Description. - The valve is relatively large with a shallow lateral depression and a well-developed keel. Juvenile ribs are of the "mortilleti" type. Rather adult ribs, slightly convex above the keel, proceeding obliquely to the symphysal margin, are subangular in the vicinity of the mentioned margin and proceed towards the apex. As for the next growth of valve, adult ribs on the flank of the valve are increasingly bended; near the symphysal margin, they are subangular. The last widely convex ribs follow the terminal outline of the valve. In the vicinity of the symphysal margin, the angularity of ribs is suppressed. The last two ribs are incomplete near the symphysal margin. The length of the preserved valve is $20 \mathrm{~mm}$.

Occurrence. - The valve was found in the area of the right tributary downstream, on the level of approximately $122 \mathrm{~m}$ in the thickness of section. Typical specimens of M. stanislavi occur, according to Měchová et al. (2010), in the Early Valanginian.

\section{Mortilletilamellaptychus cf. elegans (Renz, 1979)}

Figure 9I

1979 Lamellaptychus elegans sp. nov.; Renz, p. 593, pl. 1, figs $12 \mathrm{a}, \mathrm{b}$.

1985 Lamellaptychus elegans Renz. - Renz \& Habicht, p. 402, pl. 2, fig. 16, pl. 5, figs 17, 18 .

1996 Lamellaptychus elegans Renz. - Eliáš et al., pl. 5, fig. 3.

1996 Lamellaptychus elegans Renz. - Vašíček, pl. 3, fig. 1.

Material. - A single, quite incomplete valve (spec. GBA 2009/007/20).

Description. - The valve is small, slightly convex, with an indistinct keel. The ribs on the flanks are indistinctly convex. Near the symphysal margin, the ribs are denser and converge along a rather short part of the margin. The majority of the ribs end at the symphysal margin. Adult ribs end at the outer margin. The preserved part of the valve is approximately $6 \mathrm{~mm}$ long. Due to the incompleteness of the valve, unambiguous determination is impossible.

Occurrence. - The valve was found in the debris of the Schrambach Formation, in the uppermost part of the section, on the level of approximately $177 \mathrm{~m}$ of the thickness of the section. According to Renz \& Habicht (1985), typical representatives occur in the Early Valanginian in Switzerland.

\section{Genus Thorolamellaptychus Turculet, 1994}

Type species. - Aptychus Thoro Oppel, 1863.

\section{Thorolamellaptychus bermudensis (Renz, 1979)} Figure 10I

1979 Lamellaptychus bermudensis sp. nov.; Renz, p. 592, pl. 1, fig. 2.

2010 Thorolamellaptychus bermudensis (Renz). - Měchová et al., p. 254, fig. 10J (cum syn.). 
Material. - A single incomplete valve somewhat affected by deformation (spec. GBA 2009/009/21).

Description. - The valve is of medium size with a prominent keel and a marked lateral depression. The valve bears thin and dense ribs. In the lateral depression, ribs are slightly bent. Above the keel, the ribs bend widely so that the final parts of them are inclined to the apex. The ribs and the symphysal margin inclose at an angle of approximately 80 degrees. In the symphysal region, radial lines are distinct that lead to a slight rib undulation in the places where they intersect with the ribs. The length of the preserved valve is merely $11 \mathrm{~mm}$.

Occurrence. - The valve was found in the debris of the Schrambach Formation in the uppermost part of the section, on the level of approximately $183 \mathrm{~m}$ of the thickness of the section. In the Western Carpathians and the Northern Calcareous Alps, T. bermudensis occurs in the Late Berriasian and the Early Valanginian.

\section{Thorolamellaptychus symphysocostatus (Trauth, 1938)} Figure 10L

1938 Lamellaptychus angulocostatus (Pet.) var. n. symphysocostata; Trauth, p. 208, pl. 14, figs 15, 16.

2010 Thorolamellaptychus symphysocostatus (Trauth). Měchová et al., p. 254, fig. 10I (cum syn.).

Material. - A single valve with a missing apical area (spec. GBA 2007/007/22).

Description. - The valve is small and convex. The ribs are relatively thin and dense. On the flanks, the ribs are simple. In the vicinity of the symphysal margin, the ribs are angular so that their end parts proceed to the apex. The symphysal facet is crenulated. The preserved length is $12 \mathrm{~mm}$.

Occurrence. - The valve comes from the debris below the upper waterfall based in the Rossfeld Formation. In the Western Carpathians and the Northern Calcareous Alps, T. symphysocostatus occurs at the end of Early Valanginian and in the lower part of Late Valanginian.

\section{Thorolamellaptychus trauthi (Renz \& Habicht, 1985)} Figure 10C

1985 Lamellaptychus trauthi new form; Renz \& Habicht, p. 399, pl. 2, figs 12, 13.

2010 Thorolamellaptychus trauthi (Renz \& Habicht). Měchová et al., p. 256, fig. 10K (cum syn.).
2012 Thorolamellaptychus trauthi (Renz \& Habicht). Vašíček et al., p. 259, fig. 7.2.

Material. - A single slightly deformed valve; the anterior margin below the apex has not been preserved (spec. GBA 2009/007/23).

Description. - The valve is of medium size with a prominent keel and depression. On the flanks of the valve, the ribs are simple. Above the keel, all of the ribs are bent subangular towards the apex. In the close vicinity of the symphysal margin, the ribs are S-shaped. Juvenile and adult ribs end at the symphysal margin. The end part of the ribs proceeds to the terminal apex. The preserved part of the valve, corresponding in length to the symphysal margin, has a length of $23.5 \mathrm{~mm}$.

Occurrence. - The valve was found at 274 metres in the section, which corresponds to the level of $143.5 \mathrm{~m}$ of thickness of the section studied. According to Vašíček et al. (2012), T. trauthi occurs in the Late Berriasian and the Late Valanginian in Switzerland, Eastern Alps, Western Carpathians and Bulgaria.

\section{Comments on cephalopods}

From the list of cephalopods found in the locality of Schrambachgraben, it follows that cephalopods occur in the section in the upper part of the Schrambach Formation and on the base the Rossfeld Formation (Fig. 3). Ammonites usually occur here together with aptychi that are stratigraphically less important than ammonites.

The first findings of cephalopods in the section come from deposits above the upper edge of the lower waterfall from the higher part of the section in the Schrambach Formation. There are stratigraphically insignificant juvenile shells of smooth phylloceratids, not closely determinable, and one ribbed aptychus with a rather wide stratigraphic range.

The first stratigraphically significant finding is a large shell of the ammonite Erdenella paquieri. According to data in the literature and according to the position in the section, it can be expected that the ammonite horizon belongs to the lower or middle part of the Late Berriasian (Berriasella picteti ammonite Subzone). In the overlying layers, fragments of juvenile smooth straight shells of ammonites of the genus Bochianites occur sporadically, sometimes with incomplete valves of inoceramid bivalves. In the debris in the channel of the stream, which indicates that they were transported, two imperfectly preserved representatives of the genus Berriasella were found. The rare macrofauna, indicating the Late Berriasian, corresponds in the section to the part of thickness of 123-147 m. 
From the level of $169 \mathrm{~m}$ to the end of the accessible part of the Schrambach Formation, relatively richer findings of ammonites, partly aptychi, follow, in contrast to the previous part. The ammonites were found both in outcrops and in the debris in the channel of a steep stream, in the folded part of the Schrambach Formation. However, in addition to stratigraphically insignificant species (lytoceratids, haploceratids), species of zone and subzone significance occur. Lowermost in the mentioned part, Tirnovella alpillensis was found. According to data in the literature, the mentioned species occurs in the subzone of the same name and in the overlying subzone with Thurmanniceras otopeta in the Late Berriasian (in the Subthurmannia boissieri Zone). Somewhat higher, along with other species of the Late Berriasian, Thurmanniceras otopeta (uppermost Berriasian) of zone significance occurs, and in the surrounding debris several typically incomplete specimens of Thurmanniceras pertransiens (basal Valanginian) occur. According to the ammonites, the uppermost accessible part of the Schrambach Formation should belong to the uppermost Berriasian. Th. pertransiens is, with the maximum probability, transported from a higher part of the Schrambach Formation.

A finding from the debris of the Schrambach Formation, which is entirely exceptional in the set of the abovementioned ammonites, is represented here by Valanginites bachelardi. According to data in the literature, this species occurs in the Late Valanginian, which indicates that this specimen was transported over a great distance by water, even from the overlying Rossfeld Formation.

The basal part of the Rossfeld Formation corresponding to the lower Rossfeld Formation sensu Weber (1942) provided not too abundant ammonites and aptychi (Olcostephanus balestrai, Valanginites nucleus, Neocomites neocomiensis and Thorolamellaptychus symphysocostatus are the most significant - see Fig. 10) partly in outcrops and partly in the debris. With respect to the bad preservation of $N$. neocomiensis the specimen is only figured. The listed species prove the Neocomites peregrinus ammonite Zone.

Upper Berriasian ammonites that we found in the Schrambach Formation in the Schrambachgraben section in 2000-2001 represented, at that time, the first ammonites unknown earlier in the Lower Tirolic of the central area of the Northern Calcareous Alps. The ammonites were processed taxonomically in the year 2002 but submitted for print only at the present time.

Recently, Bujtor et al. (2013), resp. Krische et al. (2013) described an ammonite association from the Schrambach Formation from the Leube Quarry near Salzburg; the association is somewhat similar to that previously mentioned. Boorová et al. (2000) studied the same deposits on abandoned, rather high quarry levels of the Leube Quarry, and the authors did not succeed at that time in finding ammonites of that age.
In the ammonite association found in the Schrambach Formation in the Schrambachgraben type section, ammonites of the Mediterranean bioprovince, known especially from Spanish, French, Bulgarian and Crimean localities, predominate. The ammonites document the Upper Berriasian and partly the Lower Valanginian sediments. The base of the Rossfeld Formation, contacting tectonically the Schrambach Formation in the locality under study, contains sporadic Late Valanginian ammonites. The occurrence of ammonites of the genus Valanginites is of palaeogeographical interest in both formations because it is a cosmopolitan genus. In addition to Mediterranean localities, the occurrence of ammonites is also known from localities of boreal character in Germany and Poland.

\section{Discussion}

In connection with the field work performed in 2000-2001 in the classical Schrambachgraben section south of Salzburg, and after basic, especially lithological, processing published by Rasser et al. (2003), we proceeded to the detailed biostratigraphical processing of microfossil and macrofaunistic contents in all of the formations accessible in the mentioned section.

The studied Schrambachgraben section begins in the uppermost part of the Oberalm Formation, runs through the Schrambach Formation, for which the studied locality is the type section, and ends in the lower part of the Rossfeld Formation.

In the entire studied sequence of rocks of the Oberalm and the Schrambach formations in the Schrambachgraben section, we face, with certain exceptions, a shortage and unfavourable preservation of calpionellids (unsuitable cuts, recrystallization, deformation). This fact along with the transport of material and the redeposition of fossil remains, including calpionellids, occasionally causes problems in the determination of the stratigraphic position of the examined sediments based on the calpionellids. This problem primarily concerns the lower and the uppermost part of the Schrambach Formation, where it was not possible to determine standard calpionellid zones or subzones.

The Oberalm Formation contains the following association of calpionellids: Calpionella alpina, C. elliptica, Tintinnopsella carpathica, Remaniella catalonoi, $R$. duranddelgai, R. filipescui and also sporadically Crassicollaria parvula, which most likely represents a redeposit. This association indicates the standard calpionellid Calpionella Zone, Elliptica Subzone. The mentioned subzone begins in the uppermost part of the Lower Berriasian, and/or in the Middle Berriasian, and ends in the Middle Berriasian. Deposits of the Oberalm Formation in the Schrambachgraben section represent the Middle Berriasian. 
In the association of non-calcareous dinoflagellates, dinoflagellate cysts of both Late Jurassic age (Amphorula metaelliptica, Nannoceratopsis gracilis, N. pelucida, Systematophora orbifera) and of Berriasian age (Achomosphaera neptunii, Ctenidodinium elegantulum, Diacanthum hollisteri, Muderongia neocomica) were found in the Oberalm Formation.

Based on the calcareous dinoflagellates of the Fusca Acme Zone (according to the lithology) between the Middle and the Late Berriasian, a conventional boundary was determined, lying on the base of the layer from which the thin section "uw23" (from the level of $38.5 \mathrm{~m}$ of thickness in the main section - see Fig. 3). This layer is also the lithological boundary determined conventionally between the Oberalm and the Schrambach formations. However, this boundary is not proved by Late Berriasian calpionellids.

The lower part of the Schrambach Formation is largely exposed and ends in the lower waterfall at the level of thickness at approximately $87 \mathrm{~m}$. In these deposits, no macrofossils were found. According to calpionellids that occur in the given part, i.e., Calpionella alpina, C. elliptica, Tintinnopsella carpathica, T. longa, T. subacuta, Remaniella borzai, $R$. cadischiana, $R$. catalanoi, $R$. colomi, $R$. duranddelgai, $R$. filipescui, cf. Crassicollaria sp. and very rarely Calpionellopsis simplex, the lower part of the formation occupies stratigraphically the Late Berriasian. After a short interruption in the section, another part of 10 m thickness (samples "wf13-19") documented by M. Rasser (in the year 2001) follows in the side ravine. At the beginning, only sporadic calpionellids occur there in thin sections. Unfortunately, any samples for noncalcareous dinoflagellates were obtained there. In the uppermost part of this area, the calpionellid association of the Upper Berriasian similar in calpionellid composition to that in the underlying layers (with the exception of Calpionellopsis simplex) occurs in a limestone horizon (sample "wf19"). From the lithological perspective, the occurrence of several layers of variegated marls, which occur below the lower waterfall merely redeposited in the debris in the creek, is remarkable here (see Fig. 3).

What follows is an inaccessible and undocumentable part located in the below end of the waterfall, with a thickness of approximately $3 \mathrm{~m}$. In the continuation of the section in the Schrambach Formation from the upper edge of the waterfall to the level of $108 \mathrm{~m}$ thickness, there are zonal calpionellids, namely Calpionellites darderi and Cts. major. These calpionellids indicate the standard zone of Calpionellites, the occurence of which begins in the Early Valanginian; we also noticed Cts. uncinata here. In the association of calpionellids, redeposited forms that belong to crassicollarians represented by Crassicollaria parvula, Cr. colomi, Cr. massutiniana and $\mathrm{Cr}$. intermedia were found. In this hori- zon, the first occurrence of Calpionellopsis oblonga was recorded as well.

The degree of preservation of allochems, primarily of allochems and biogens, indicates that material has been transported along the Schrambach and the studied part of the Oberalm Formation. This transport is evidenced by the presence of redeposited and deformed calpionellids, the occurrence of partially "buried" allochems in the matrix and the mutual amputation of individual components.

From the lithological perspective shaly and silty marlstones occur in this part of sequence of the Schrambach Formation for the first time.

According to micropalaeontological data, it can be presumed that in the vicinity of the upper edge of the waterfall, in the inaccessible part in the waterfall, a tectonic line, which separates the lower part of the Schrambach Formation from the second tectonic slice of the Schrambach Formation containing Early Valanginian calpionellids, runs. An indirect indication is clearly visible undulation of strata in the uppermost part of the waterfall overlying flat dipping beds in the lower part of the waterfall.

The end of the Valanginian slice in the section is not clear. Based on lithology, but especially according to the finding of a Late Berriasian ammonite Erdenella paquieri at the level of $123 \mathrm{~m}$ thickness, we suppose that the next significant tectonic line is there at approximately the level of $120 \mathrm{~m}$. The tectonic setting cannot be directly observed. At the above mentioned level, the mouth of a smaller right tributary is located and in a single point in the stem stream in the entire studied section; the direction of the stem stream changes from west-east to north-south in the length of several tens of metres.

The overlying tectonic slice is notable for the macrofossil occurrences. In the taxonomic part, 10 species of ammonites, partly of guide character (of which one represents a new species Schrambachoceras weidichi) and 4 species of aptychi were described. This part of the formation differs from the underlying part in lithology; in the upper part of the formation, thicker layers of softer silty marls occur in addition to sandy weathered laminated marlstones and relatively stable marlstones in the lower part of the rhythms.

The first stratigraphically significant finding here is the ammonite Erdenella paquieri (niveau 123 m of thickness), which indicates the Late Berriasian (Subthurmannia boissieri Zone). This zone is also indicated by the occurrence of the cyst Pseudoceratium pelliferum. The first occurrence of this cyst is considered from the upper part of the Berriasella picteti ammonite Subzone.

The Late Berriasian is indicated in the section by other findings of ammonites in debris, when a mountain creek transports macrofossils within various distances, and especially by findings of ammonites in situ. The most important finding regarding the latter is Tirnovella alpillensis (on the 
level of thickness of approximately $170 \mathrm{~m}$ ). The mentioned species is a subzone species of the last but is one Late Berriasian ammonite zone of the same name. The uppermost Berriasian, i.e., the ammonite Thurmanniceras otopeta Subzone, is indicated by the finding of Thurmanniceras otopeta in debris in the layers overlying the last mentioned layer. The Late Berriasian species Thurmanniceras pertransiens, which is a zone species of basal Valanginian, occurs only in debris. We assume that shells of the mentioned guide species were transported by a watercourse from an inaccessible, overlying part of the section of the Schrambach Formation.

Occurrences of the guide calpionellids of the standard Calpionellites Zone (Calpionellites darderi and Cts. major) in the thin section "v44" (approximately $178 \mathrm{~m}$ ) correspond to this zone.

Importantly, the last described uppermost accessible part of the section (in the thicknees $123-180 \mathrm{~m}$ ) belonging to the Schrambach Formation is strongly folded, in contrast to the underlying part prevailingly of monoclinal, flat dipping beds character (see also Rasser et al. 2003, p. 198). Overturned folds with amplitude of several metres indicate tectonic manifestations. We connect the folded part with tectonic processes with which tectonic contact between the Schrambach Formation and the overlying Rossfeld Formation should be exposed in the inaccessible part of the section.

After a rather long inaccessible part in the uppermost part of the deposits of the Schrambach Formation, only the lower or basal part of the Rossfeld Formation is accessible. From this part of the Rossfeld Formation, samples for thin sections and 5 samples for non-calcareous dinoflagellates were obtained. Macrofossils were also found: 3 species of ammonites and one species of aptychi are described in the taxonomic portion of the paper. The lowermost accessible part of the Rossfeld Formation belongs, based on the found ammonites Valanginites nucleus to the Late Valanginian, to the ammonite Neocomites peregrinus Zone. Cysts, e.g., Cymososphaeridium validum, Muderongia macwhaei and Spiniferites ramosus also indicate the Late Valanginian; however, calpionellids are missing in the matrix. Calpionella alpina was identified only in clasts.

Ammonite zones of the upper Early Valanginian and the basal LateValanginian were not detected. It is probable that at least one of the ammonite zones, if not both of them, are missing for tectonical reasons. Deposits of the uppermost part of the Schrambach Formation were tectonically amputated in the course of the overthrust of deposits of the Rossfeld Formation.

\section{Conclusions}

1. The type section of the Schrambach Formation in the locality of Schrambachgraben south of Salzburg represents a long, approximately $150 \mathrm{~m}$ thick, relatively continuous succession of rocks in a cut of the Schrambach mountain creek. The Schrambach Formation is underlain by the uppermost part of the Oberalm Formation. Lithologically, the Oberalm Fm. passes gradually to the Schrambach Fm. We have conventionally placed a boundary between both the formations to the level of $38.5 \mathrm{~m}$ in the overlying beds at the beginning of the studied section. Approximately in the same place, the Middle/Late Berriasian boundary is there, according to calcareous dinoflagellates corresponding to the Fusca Acme Zone.

2. A Middle Berriasian age of the Oberalm Formation is documented by an association of calpionellids, which prove the standard Calpionella calpionellid Zone, Elliptica Subzone.

3. The sequence of strata in the type section of the Schrambach Formation is tectonically complicated; it consists of three tectonic slices at a minimum. In the lower slice, which continuously follows the underlying Oberalm Formation and ends below the upper edge of the lower waterfall, is located the lower part of Late Berriasian. The stratigraphy was based on the occurrence of calpionellids (Tintinnopsella subacuta the first occurence is connected with Calpionellopsis Zone, Oblonga Subzone and in higher horizons with sporadic Calpionellopsis simplex), calcareous and noncalcareous dinoflagellates. The deposits belong to the Late Berriasian.

4. The higher tectonic slice belongs, according to micropalaeontology, to the Early Valanginian, which is evidenced especially by calpionellids Calpionellites darderi and Calpionellites major.

5. The uppermost sequence of the strata of the Schrambach Formation is composed predominantly of deposits of higher Upper Berriasian (ammonite Subthurmannia boissieri Zone). This Upper Berriasian lithologically differs from the underlying tectonic slices by a predominance of shaly silty marlstones, the absence of mudstones, and of variegated marlstones; for the first time, cephalopods appear. The oldest ammonite finding represents Erdenella paquieri. The stratigraphic range of the mentioned species is rather wide; it occurs nearly entirely in the Late Berriasian. According to the first occurrence of the non-calcareous dinoflagellate Pseudoceratium peliferum, situated in the vicinity of the mentioned ammonite, the base of the mentioned slice is in the upper part of the Berriasella picteti Subzone.

6. According to other findings of ammonites, the uppermost Berriasian is indicated as well. In the bedrock, the zone ammonite Tirnovella alpillensis ammonite Zone was 
found, and this species along with Thurmanniceras otopeta were found in the debris. Moreover, the Lower Valanginian is documented, namely by a redeposited guide ammonite Thurmanniceras pertransiens. The Lower Valanginian in the uppermost accessible part of the section with the Schrambach Formation is also evidenced by sporadic occurrences of Calpionellites darderi and Calpionellites major in thin sections.

7. The uppermost accessible deposits in the studied section belong to the lower part of the Rossfeld Formation. According to the ammonites and the non-calcareous dinocysts, the mentioned deposits belong to the Late Valanginian, Neocomites peregrinus ammonite Zone.

8. Based on the integrated biostratigraphy (calpionellids, ammonites, aptychi, calcareous and non-calcareous dinoflagellates), the stratigraphic succession of rocks (the Oberalm, Schrambach, Rossfeld formations) in the Schrambachgraben locality in the range from Middle Berriasian to Upper Valanginian was determined.

\section{Acknowledgements}

The fieldwork was carried out within the bilateral cooperation programme between the Czech, Slovak and Austrian Geological Surveys. The processing of dinocysts and cephalopods, the elaboration of a prevailing part of the manuscript in Ostrava, and others were possible thanks to the support of the Grant SP2014/11 from the Ministry of Education, Youth and Sports of the Czech Republic, later for support by the Project for Long-Term Strategic Development of the Institute of Geonics, Czech Academy of Sciences. Reviewers, A. Lukeneder (Museum of Natural History, Vienna, Austria), and J. Michalík (Slovak Academy of Sciences, Bratislava, Slovakia) are thanked for their constructive remarks and suggestions. The authors thank J. Vondráková for drawing and K. Mezihoráková for making photos. We also express our thanks to R. Jelínková and J. Pevný for the primary translation into English. The authors thank to the editor C. Janda from Abhandlungen der Geologischen Bundesanstalt for his correctitude and stimulating comments on the first version of the manuscript.

\section{References}

Andreini, G., Caracuel, J.E. \& Parisi, G. 2007. Calpionellid biostratigraphy of the Upper Tithonian-Upper Valanginian interval in Western Sicily (Italy). Swiss Journal of Geosciences 100, 179-198. DOI 10.1007/s00015-007-1227-z

Arkadiev, V.V. \& Bogdanova, T.N. 2004. Genus Berriasella (Ammonoidea) and Ammonoid Zonation in the Berriasian of the Crimea Mountains. Stratigraphy and Geological Correlation 12(4), 367-379.

Arkadiev, V.V. \& Bogdanova, T.N. 2012. Golovonogie mollyuski (ammonity), 123-224. In ARKadiEv, V.V., BoG-
Danova, T.N., Guzhikov, A.Y., Lobacheva, S.V., Myshkina, N.V., Platonov, E.S., Saveleva, Y.N., Shurekova, O.V. \& JAnIN, B.T. (eds) Berrias Gornogo Kryma. Sankt-Peterburg. [in Russian]

ARnould-SAGET, S. 1953. Les ammonites pyriteuses du Tithonique supérieur et du Berriasien de Tunisie centrale. Annales des Mines et de la Géologie Tunis 10 (for 1951), $1-133$.

Blanford, H.F. 1864. On Dr. Gerard's collection of fossils from the Spiti valley, in the Asiatic Society's Museum. Journal of the Asiatic Society of Bengal 32, 124-138.

Boorová, D., Lobitzer, H., Skupien, P. \& VAšíček, Z. 2000. Biostratigraphy and facies of Upper Jurassic-Lower Cretaceous pelagic carbonate sediments (Oberalm-, Schrambachand Rossfeld Formation) in the Northern Calcareous Alps, South of Salzburg. Abhandlungen der Geologischen Bundesanstalt 56, 273-318.

Bujtor, L., Krische, O. \& Gawlick, H.-J. 2013. Late Berriasian ammonite assemblage and biostratigraphy of the Leube quarry near Salzburg (Northern Calcareous Alps, Austria). Neues Jahrbuch für Geologie und Paläontologie, Abhandlungen 267(3), 273-295. DOI 10.1127/0077-7749/2013/0309

Company, M. 1987. Los ammonites del Valanginiense del sector oriental de las Cordilleras Béticas (SE de España). 294 pp. Ph.D. thesis, University of Granada.

DuAnélidzé, A. 1922. Les Spiticeras du Sud-Est de la France. Mémoires pour Servir à l'Éxplication de la Carte géologique détaillée de la France, 1-255.

Dunham, R. J. 1962. Classification of carbonate rocks according to depositional texture, 108-121. In HAM, W.E. (ed.) Classification of Carbonate Rocks. American Association of Petroleum Geologist, Memoir 1.

Eliáš, M., Martinec, P., Reháková, D. \& VAŠíčeK, Z. 1996. Geologie a stratigrafie kurovických vápenců a tlumačovských slínovcům v kurovickém lomu (svrchní jura - spodní křída, vnější Západní Karpaty, Česká republika). [Geology and stratigraphy of the Kurovice Limestone and Tlumačov Marl Formation at the Kurovice Quarry (Upper Jurassic-Lower Cretaceous, Outer Western Carpathians, Czech Republic).] Věstník Českého geologického ústavu 71, 259-275. [in Czech, with English abstract]

ERISTAVI, M.S. 1961. Nekotorye nizhnemelovye golovonogie Central'nych Karpat. Geologické práce, Zprávy 21, 81-108. [in Russian, with German résumé]

Faraoni, P., Flore, D., Marini, A., Pallini, G. \& Pezzoni, N. 1997. Valanginian and early Hauterivian ammonite successions in the Mt Catria group (Central Apennines) and the Lessini Mts (Southern Alps), Italy. Palaeopelagos 7, 59-100.

Fensome, R.A. \& Williams, G.L. 2004. The Lentin and Williams index of fossil dinoflagellates 2004 edition. American Association of Stratigraphic Palynologists, Contributions Series 42, $1-909$.

Fischer, J.-C., Gauthier, H., De Busnardo, R., Combemorel, R., Delanoy, G., Guérin-Franiatte, S., Joly, B., Kennedy, W. J. \& Tintant, H. 2006. Premiere Partie. Révision critique de la Paléontologie française d'Alcide d'Orbigny, volume IV: Céphalopodes crétacés, 1-292. Seconde Partie. Réédition du tome premier (terrains crétacés, Céphalopodes) de la Paléon- 
tologie française d'Alcide d'Orbigny (édition originale). 622 pp. Supplément (terrains crétacés) à la Paléontologie française d'Alcide d'Orbigny (édition originale 1847). 28 pp. Backhuys, Leiden.

FoLK, R. L. 1962. Spectral subdivision of limestone types, 62-84. In HAM, W.E. (ed.) Classification of Carbonate Rocks. American Association of Petroleum Geology, Memoir 1.

Frisch, W. \& GAwLICK, H.-J. 2003. The nappe structure of the Central Northern Calcareous Alps and its disintegration during Miocene tectonic extrusion - a contribution to understanding the orogenic evolution of the Eastern Alps. International Journal of Earth Sciences 92, 712-727.

Gradstein, F.M., OGG, J.G., Schmitz, M.D. \& OGG, G.M. (eds) 2012. The Geologic Time Scale 2012. 597 pp. Elsevier, Oxford.

GRÜN, B. \& BLAU, J. 1997. New aspects of calpionellid biochronology: proposal for a revised calpionellid zonal and subzonal division. Revue de Paléobiologie 16(1), 197-214.

Kakabadze, I.M., KaKabadze, M.V., Kvantaliani, I.V., Kotetishvili, E.V. \& SharikadZe, M.Z. 2005. Otrjad Ancyloceratida, 346-403. In TopchishviLi, M.V. (ed.) Atlas rannemelovoi fauny Gruzii [Atlas of Early Cretaceous fauna of Georgia]. Trudy Geologicheskogo instituta im. A.I. Dzhanelidze, Novaya seriya 120. [in Russian]

Kilian, W. 1910. Erste Abteilung: Unterkreide (Palaeocretacicum). Lieferung 2: Das bathyale Palaeocretacicum im südostlichen Frankreich; Valendis-Stufe, Hauterive-Stufe; Barreme-Stufe; Apt-Stufe, 169-288. In FRECH, F. (1907-1913) Lethaea Geognostica. II. Das Mesozoicum, Band 3 (Kreide). Schweitzerbart, Stuttgart.

KleIN, J. 2005. Lower Cretaceous Ammonites I. Perisphinctaceae 1: Himalayitidae, Olcostephanitidae, Holcodiscidae, Neocomitidae, Oosterellidae, 1-484. In RIEGRAF, W. (ed.) Fossilium catalogus I: Animalia 139. Backhuys Publishers, Leiden.

Klein, J., Busnardo, R., Company, M., Delanoy, G., Kakabadze, M., Reboulet, S., Ropolo, P., Vašíček, Z. \& Vermeulen, J. 2007. Lower Cretaceous Ammonites III. Bochianitoidea, Protancyloceratoidea, Ancyloceratoidea, Ptychoceratoidea, 1-381. In RIEgraf, W. (ed.) Fossilium Catalogus I: Animalia 144. Backhuys Publishers, Leiden.

Koenen, A. von 1909. Die Polyptychites-Arten des Unteren Valanginien. Abhandlungen der Königlichen Preussischen geologischen Landesanstalt, Neue Folge 59, 1-89.

Krische, D., Bujtor, L. \& Gawlick, W.-J. 2013. Calpionellid and ammonite biostratigraphy of uppermost Jurassic to Lower Cretaceous sedimentary rocks from the Leube Quarry (Northern Calcareous Alps, Salzburg, Austria). Austrian Journal of Earth Science 106(1), 26-45.

Kvantaliani, I., Topchishvili, M., Lominadze, T. \& ShariKADZE, M. 1999. Upon the Systematics of the Mesozoic Ammonitida. Bulletin of the Georgian Academy of Sciences $160,102-105$.

LeanZA, H.A. \& Wiedmann, J. 1989. Nuevos ammonites del Berriasiano/Valanginiano (Crétacico inferior) de Neuquén, Argentina, 793-810. In WiedmanN, J. (ed.) Cretaceous of the Western Tethys, Proceedings $3^{\text {rd }}$ International Symposium, Tübingen 1987. Schweitzerbart, Stuttgart.

LeEREVELD, H. 1995. Dinoflagellate cysts from the Lower Creta- ceous Río Argos succession (SE Spain). LPP Contribution Series $2,1-175$.

LeEReveld, H. 1997. Upper Tithonian-Valanginian (Upper Jurassic - Lower Cretaceous) dinoflagellate cyst stratigraphy of the western Mediterranean. Cretaceous Research 18, 385-420. DOI 10.1006/cres.1997.0070

LiLIENBACH, L.A. von 1830. Ein Durchschnitt aus den Alpen mit Hindeutung auf die Karpathen. Jahrbuch für Mineralogie, Geognosie Heidelberg 1, 153-220.

LIPOLD, M.W. 1854. Der Salzberg am Dürnberg nächst Hallein. Jahrbuch der kaiserlich-königlichen Geologischen Reichsanstalt 5, 590-610.

Mazenot, G. 1939. Les Palaeohoplitidae tithoniques et berriasiens du Sud-Est de la France. Mémoires de la Société geologique de France, Nouvelle série 18, Mémoire 41, 1-303.

MĚchovÁ, L., VAšíčEK, Z. \& HoušA, V. 2010. Early Cretaceous ribbed aptychi - a proposal for a new systematic classification. Bulletin of Geosciences 85(2), 219-274.

DOI 10.3140/bull.geosci.1162

Mikhailova, I.A. \& Baraboshinin, E.Y. 2009. Evolyutsiya geteromorfnykh i monomorfnykh rannemelovykh ammonitov podotryada Ancyloceratina Wiedmann [Evolution of Heteromorph and Monomorph Early Cretaceous Ammonites of the Suborder Ancyloceratina Wiedmann]. Paleontologicheskii zhurnal 2009(5), 51-60. [in Russian]

Missoni, S. \& GawLICK, H.-J. 2011. Jurassic mountain building and Mesozoic-Cenozoic geodynamic evolution of the Northern Calcareous Alps as proven in the Berchtesgaden Alps (Germany). Facies 57, 137-186. DOI 10.1007/s10347-010-0225-1

MonteIL, E. 1992. Kystes de dinoflagellés index (Tithonique-Valanginien) du Sud-Est de la France: Proposition d'une nouvelle zonation palynologique. Revue de Paléobiologie 11(1), 299-306.

MonteIL, E. 1993. Dinoflagellate cyst biozonation of the Tithonian and Berriasian of south-east France. Correlation with the sequence stratigraphy. Bulletin des Centres de recherches Exploration Production Elf-Aquitaine 17, 249-273.

Neumayr, M. 1875. Die Ammoniten der Kreide und die Systematik der Ammonitiden. Zeitschrift der Deutschen geologischen Gesellschaft 27, 854-942.

Nikolov, T.G. 1960. Amonitna fauna ot valanzha v Iztochniya Predbalkan. Trudove varkhu Geologyiata na Balgariya, Seriya Paleontologiya 2, 143-206. [in Bulgarian with French résumé]

NikoLov, T.G. 1966. New genera and subgenera of ammonites of family Berriasellidae. Doklady Balgarskoi akademii nauk 19, 639-642.

Nikolov, T.G. 1967. Les ammonites berriasiennes du genre Protoleptoceras Nikolov. Izvestiya na Geologicheskiya Institut, Seriya Paleontologiya 16, 35-40.

Nikolov, T.G. 1979. A new ammonite subgenus Jabronella (Erdenella) subgen. n. (Berriasellidae, Tithonian-Berriasian). Doklady Balgarskoi akademii nauk 32, 337-340.

Nikolov, T.G. 1982. Les ammonites de la famille Berriasellidae Spath, 1922. Tithonique supérieur - Berriasien. 251 pp. Editions Académie bulgare des sciences, Sofia.

Ooster, W.A. 1860. Catalogue des Céphalopodes fossiles des Alpes suisses avec la description et les figures des espèces 
remarquables. V. Céphalopodes tentaculifères, Ammonitides. Nouveaux Mémoires de la Société helvetique des Sciences naturalles 18, 1-100.

Oppel, A. 1863. Über jurassische Cephalopoden. Paläontologische Mittheilungen aus dem Museum des Königlichen Bayerischen Staates 3, 127-266.

ORBigny, A. D’ 1840-1842. Paléontologie française. Description zoologique et géologique de tous les animaux mollusques et rayonnés fossiles de France. Terrains Crétacés. Vol. 1 Céphalopodes. 120 pp. Arthus-Bertrand d'Orbigny, Paris.

Orbigny, A. D' 1850. Prodrome de Paléontologie stratigraphique universelle des animaux mollusques et rayonnés, faisant suite au cours élementaire de paléontologie et de géologie stratigraphiques 2.427 pp. Masson, Paris. DOI 10.5962/bhl.title.62810

Pictet, F.J. 1867. Études paléontologiques sur la faune à Terebratula diphyoides de Berrias (Ardèche). Mélanges paléontologiques 1(2), 44-130.

Pictet, F.J. \& Campiche, G. 1858-1860. Description des fossiles du terrain Crétacé des environs de Sainte-Croix, part 1. Matériaux pour la Paléontologie Suisse (series 2) 1860, 209-380.

PICTET, F.J. \& LoRIOL, P. 1858. Description des fossiles contenus dans les terrains néocomiens des Voirons. Matériaux pour la paléontologie de la Suisse 2, 1-64.

Piller, W.E., Egger, H., Erhart, C.W., Gross, M., Harzhauser, M., Hubmann, B., van Husen, B., Krenmayr, H.-G., KrysTyn, L., Lein, R., Lukeneder, A., Mandl, G.W., RöGl, F., Roetzel, R., Rupp, C., Schnabel, W., Schönlaub, H.P., Summesberger, H., Wagreich, M. \& Wessely, G. 2004. Die stratigraphische Tabelle von Österreich 2004 (Sedimentäre Schichtfolgen). Österreichische Stratigraphische Kommission. Gerin, Wolkersdorf.

Ploch, I. 2003. Taxonomic interpretation and sexual dimorphism in the Early Cretaceous (Valanginian) ammonite Valanginites nucleus (Roemer, 1841). Acta Geologica Polonica 53, 201-208.

PoP, G. 1994a. Systematic revision and biochronology of some Berriasian-Valanginian calpionellids (genus Remaniella). Geologica Carpathica 45(6), 323-331.

PoP, G. 1994b. Calpionellid evolutive events and their use in biostratigraphy. Romanian Journal of Stratigraphy 76, 7-24.

Pop, G. 1996. Trois nouvelles espèces du genre Remaniella (Calpionellidae Bonet, 1956). Paléontologie, Compte Rendu de l'Academie des sciences 322(IIa), 317-323.

Pop, G. 1997. Tithonian to Hauterivian praecalpionellids and calpionellids bioevents and biozones. Mineralia Slovaca 29(4-5), 304-305.

Rasser, M.W., VAšíček, Z., Skupien, P., Lobitzer, H. \& BoorovÁ, D. 2003. Die Schrambach-Formation an ihrer Typuslokalität (Unter-Kreide, Nördliche Kalkalpen, Salzburg): Lithostratigraphische Formalisierung und „historische“ Irrtümer, 193-216. In Piller, W.E. (ed.) Stratigraphia Austriaca, Österreichische Akademie der Wissenschaften, Schriftenreihe der Erdwissenschaftlichen Kommissionen 16. Wien.

Reboulet, S. 1996. L'évolution des ammonites du Valanginien-Hauterivien inférieur du bassin vocontien et de la plate-forme provencale (Sud-Est de la France): relations avec la stratigraphie séquentielle et implications biostratigraphiques. Documents des Laboratoires de Géologie Lyon 137, 1-371.

Reboulet, S., Rawson, P.F., Moreno-Bedmar, J.-A., Aguirre-Urreta, M.B., Barragán, R., Bogomolov, Y., Company, M. \& GonZÁles-Arreola, C. et al. 2011. Report on the $4^{\text {th }}$ International Meeting of IUGS Lower Cretaceous Ammonite Working Group, the "Kilian Group" (Dijon, France $30^{\text {th }}$ August 2010). Cretaceous Research 32, 786-793.

ReHÁkovÁ, D. 2000a. Evolution and distribution of the Late Jurassic and Early Cretaceous calcareous dinoflagellates recorded in the Western Carpathian pelagic carbonate facies. Mineralia Slovaca 32(2), 79-88.

ReHÁKovÁ, D. 2000b. Calcareous dinoflagellate and calpionellid bioevents versus sea-level fluctuations recorded in the WestCarpathian (Late Jurassic/Early Cretaceous) pelagic environments. Geologica Carpathica 51(4), 229-243.

ReHÁKovÁ, D. \& MichaLíK, J. 1997. Evolution and distribution of calpionellids - the most characteristic constituents of Lower Cretaceous Tethyan microplancton. Cretaceous Research 18, 493-504. DOI 10.1006/cres.1997.0067

RenZ, O. 1979. Aptychi (Ammonoidea) and ammonites from the Lower Cretaceous of the western Bermuda Rise, Leg 43, Site 387, DSDP, 591-596. In Tucholke, B.E. \& Vogt, P.R. et al. (eds) Initial Reports of the Deep Sea Drilling Project 43. Washington.

RenZ, O. \& Habicht, K. 1985. A correlation of the Tethys Maiolica Formation of the Breggia section (southern Switzerland) with Early Cretaceous coccolith oozes of Site 534A, DSDP Leg 76 in the western Atlantic. Eclogae geologicae Helvetiae 78, 383-431.

Rodighiero, A. 1919. Il sistema Cretaceo del Veneto occidentale compreso fra l'Adige e il Piave noc speciale riguardo al Neocomiano dei Setti Comuni. Palaeontographia italica 25, 70-125.

RoEMER, F.A. 1841. Die Versteinerungen des norddeutschen Kreidegebirges 2, 49-145. Hahn, Hannover.

SAYN, G. 1899. Note sur quelques ammonites nouvelles ou peu connues de Néocomien inférieur. Bulletin de la Société géologique de France (séries 3) 17, 679-688.

SAYN, G. 1907. Les ammonites pyriteuses des Marnes valanginiennes de Sud-Est de la France (part 2). Mémoires de la Société géologique de France, Paléontologie 15, Mémoire 23, 29-68.

SimionESCU, I. 1899. Note sur quelques ammonites du Néocomien français. Travaux du Laboratoire de géologie de la Faculté des sciences de Grenoble 11,1-16.

Skupien, P. \& SMARŽOvÁ, A. 2011. Palynological and geochemical response to environmental changes in the Lower Cretaceous in the Outer Western Carpathians; a record from the Silesian unit, Czech Republic. Cretaceous Research 32(4), 538-551. DOI 10.1016/j.cretres.2011.04.001

SKUPIEN, P. \& VAŠíčEK, Z. 2002. Lower Cretaceous ammonite and dinocyst biostratigraphy and paleoenvironment of the Silesian basin (Outer Western Carpathians). Geologica Carpathica 53(3), 179-189.

Spath, L.F. 1924. On the ammonites of the Speeton Clay and the subdivisions of the Neocomian. Geological Magazine 61, 73-89. DOI 10.1017/S0016756800083588 
Stover, L.E., Brinkhuis, H., Damassa, S.P., De Verteuil, L., Helby, R.J., Monteil, E., Partridge, A.D., Powell, A.J., Riding, J.B., Smelror, M. \& Williams, G.L. 1996. Mesozoic-Tertiary dinoflagellates, acritarchs and prasinophytes, 641-750. In Jansonius, J. \& Mc Gregor, D.C. (ed.) Palynology: principles and applications, American Association of Stratigraphic Palynologists Foundation 2.

Svobodová, M., Švábenická, L., Skupien, P. \& Hradecká, L. 2011. Biostratigraphy and paleoecology of the Lower Cretaceous sediments in the Outer Western Carpathians (Silesian Unit, Czech Republic). Geologica Carpathica 62(4), 309-332. DOI 10.2478/v10096-011-0024-9

Tavera Benitez, J.M. 1985. Los ammonites del Tithonico Superior-Berriasense de la zona subbetica (Cordilleras Beticas). 381 pp. Ph.D. thesis, University of Granada.

Thieuloy, J.-P. 1979. Les ammonites. Description des espèces indices et de quelques autres formes fondamentales, 37-58. In Busnardo, R., Thieuloy, J.-P. \& Moullade, M. (eds) Hypostratotype mésogéen de l'étage Valanginien (Sud-Est de la France). Paris.

Trauth, F. 1927. Aptychenstudien I. Über die Aptychen im Allgemeinen. Annalen des Naturhistorischen Museums in Wien 41, 171-259.

Trauth, F. 1938. Die Lamellaptychi des Oberjura und der Unterkreide. Palaeontographica, Abteilung A 88, 118-240.

TuRCulet, I. 1994. Asupra oportunităii separării de parasubgenerui in cadrul paragenerului Lamellaptychus (Cephalopoda, Ammonoidea). Studii și Cercetări de Geologie, Geofizică, Geografie, Serie Geologica 39, 119-126.

Uhlig, V. 1883. Die Cephalopodenfauna der Wernsdorfer Schichten. Denkschriften der Kaiserlichen Akademie der Wissenschaften, mathematisch-naturwissenschaftliche Klasse 46, 127-290.

Uhlig, V. 1903. The fauna of the Spiti Shales. Palaeontologia Indica, Memoirs of the Geological Survey of India, Series 15, Himalayan Fossils 4, 1-132.

Uhlig, V. 1905. Einige Bemerkungen über die Ammoniten- gattung Hoplites Neumayr. Sitzungsberichte der Kaiserlichen Akademie der Wissenschaften in Wien, mathematischnaturwissenschaftliche Klasse 114, 591-636.

VAŠičEK, Z. 1996. Aptychi and stratigraphy of the Lower Cretaceous in the Western Carpathians. Mitteilungen, Geologischpaläontologisches Institut der Universität Hamburg 77, 221-241.

VAŠÍČEK, Z. \& FAUPL, P. 2000. Zur Biostratigraphie der Schrambachschichten in der Reichraminger Decke (Unterkreide, oberösterreichische Alpen). Abhandlungen der Geologischen Bundesanstalt 56(2), 593-624.

VAŠ́̌čEK, Z. \& HoEdeMAEKER, P.J. 2003. Small Berriasian, Lower Valanginian and Barremian heteromorphic ammonites from the Río Argos succession (Caravaca, south-east Spain). Scripta geologica 125, 11-33.

Vašiček, Z., Motchurova-Dekova, N., Ilcheva, A. \& MetoDIEV, L. 2012. Taxonomy of Late Jurassic - Early Cretaceous aptychi from Bulgaria. Neues Jahrbuch für Geologie und Paläontologie, Abhandlungen 265(3), 249-274.

DOI 10.1127/0077-7749/2012/0257

VAŠíčEK, Z., REHÁKOVÁ, D. \& FAUPL, P. 2000. Zur Biostratigraphie der Schrambachschichten der Oisbergmulde bei Hollenstein a. d. Ybbs (Lunzer Decke, Kalkalpen, Niederösterreich). Abhandlungen der Geologischen Bundesanstalt 56(1999), 625-650.

VERMEULEN, J. 2006. Nouvelle classification à fondement phylogénétique des ammonites hétéromorphes du Crétacé inférieur. Annales du Muséum d'Histoire Naturelle Nice 21, $137-178$.

Weber, E. 1942. Ein Beitrag zur Kenntnis der Rossfeldschichten und ihrer Fauna. Neues Jahrbuch für Mineralogie, Geologie und Paläontologie, Beilage-Band 86, Abteilung B, 247-281.

Wright, C.W., Callomon, J.H. \& Howarth, M.K. 1996. Cretaceous Ammonoidea. Treatise on Invertebrate Paleontology. Part L, Mollusca 4. Revised. 362 pp. Geological Society of America \& University of Kansas, Boulder \& Lawrence.

\section{Appendix}

An alphabetic index of dinocyst taxa is provided below. Taxonomic citations can be found in Fensome \& Williams (2004). Numbers in parentheses refer to the position of the species in the distribution chart of the Schrambach section (Table 1).

Achomosphaera neptuni (Eisenack, 1958a) Davey \& Williams, 1966a (16)

Achomosphaera verdieri Below, 1982c (74)

Amphorula delicata van Helden, 1986 (57)

Amphorula metaelliptica Dodekova, 1969 (40)

Biorbifera johnewingii Habib, 1972 (30)

Bourkidinium granulatum Morgan, 1975 (26)

Bourkidinium sp. 1 of Leereveld (1997) (83)

Cassiculosphaeridia reticulata Davey, 1969a (84)

Chytroeisphaeridia chytroeides (Sarjeant, 1962a) Downie \& Sarjeant, 1965 (65)

Circulodinium brevispinosum (Pocock, 1962) Jansonius, 1986 (50)
Circulodinium distinctum (Deflandre \& Cookson, 1955) Jansonius, 1986 (38)

Circulodinium vermiculatum Stover \& Helby, 1987c (32)

Circulodinium spp. (4)

Cometodinium habibii Monteil, 1991a (13)

Cribroperidinium giuseppei (Morgenroth, 1966a) Helenes, 1984 (66)

Cribroperidinium? edwardsii (Cookson \& Eisenack, 1958) Davey, 1969a (67)

Cribroperidinium orthoceras (Eisenack, 1958a) Davey, 1969a (14)

Cribroperidinium spp. (58)

Ctenidodinium elegantulum Millioud, 1969 (17)

Ctenidodinium ornatum (Eisenack, 1935) Deflandre, 1939a (27)

Cymososphaeridium validum Davey, 1982b (82)

Dapsilidinium multispinosum (Davey, 1974) Bujak et al., 1980 (54)

Dapsilidinium warrenii (Habib, 1976) Lentin \& Williams, 1981 (60) 
Diacanthum hollisteri Habib, 1972 (39)

Dichadogonyaulax bensonii Monteil, 1992a (9)

Dingodinium sp. (55)

Dissiliodinium globulus Drugg, 1978 (64)

Exiguisphaera phragma Duxbury, 1979a (7)

Exochosphaeridium muelleri Yun, 1981 (33)

Exochosphaeridium spp. (81)

Fromea cylindrica (Cookson \& Eisenack, 1960b) Stover \& Evitt, 1978 (59)

Gonyaulacysta spp. (8)

Hystrichodinium pulchrum Deflandre, 1935 (11)

Hystrichodinium voigtii Alberti, 1961 (35)

Hystrichosphaerina ?orbifera (Klement, 1960) Stover \& Evitt, 1978 (21)

Hystrichosphaerina schindewolfii Alberti, 1961 (51)

Kiokansium polypes (Cookson \& Eisenack, 1962b) Below, 1982c (46)

Kleithriasphaeridium corrugatum Davey, 1974 (49)

Kleithriasphaeridium fasciatum Davey \& Williams, 1966b (41)

Kleithriasphaeridium suevicum Dürr, 1988 (1)

Lithodinia spp. (45)

Mendicodinium spp. (68)

Microhystridium pyramidispinosum (2)

Muderongia australis Helby, 1987 (69)

Muderongia longicorna Monteil, 1991b (25)

Muderongia mcwhaei Cookson \& Eisenack, 1958 (80)

Muderongia simplex Alberti, 1961 (28)

Muderongia spp. (3)

Nannoceratopsis gracilis Alberti, 1961 (36)

Nannoceratopsis pellucida Deflandre, 1939a (31)

Nannoceratopsis spp. (77)

Nannoceratopsis triceras Drugg, 1978 (62)

Oligosphaeridium porosum Lentin \& Williams, 1981 (53)

Phoberocysta neocomica (Gocht, 1957) Millioud, 1969 (42)

Phoberocysta tabulata Raynaud, 1978 (20)

Prolixosphaeridium mixtispinosum (Klement, 1960) Davey et al., 1969 (22)

Prolixosphaeridium sp. A of Monteil (1993) (23)

Protoellipsodinium touile Below, 1981a (71)

Pseudoceratium gochtii Neale \& Sarjeant, 1962 (76)

Pseudoceratium pelliferum Gocht, 1957 (63)

Pterodinium cingulatum (O. Wetzel, 1933a) Below, 1981a (75)

Scriniodinium anceps (Raynaud, 1978) Jan du Chêne et al., 1986a (70)

Scriniodinium campanula Gocht, 1959 (34)

Sentusidinium spp. (12)

Spiniferites ramosus (Ehrenberg, 1838) Mantell, 1854 (78)

Spiniferites sp. A of Leereveld (1997) (52)

Stanfordella ?cretacea (Neale \& Sarjeant, 1962) Helenes \&

Lucas-Clark, 1997 (47)

Surculosphaeridium spp. (79)

Systematophora areolata Klement, 1960 (15)

Systematophora complicata (Neale \& Sarjeant, 1962) Eisenack, 1969a (61)

Systematophora palmula Davey, 1982b (29)
Systematophora penicillata (Ehrenberg, 1843) Sarjeant, 1980a (6)

Systematophora scoriacea (Raynaud, 1978) Monteil, 1992b (18)

Systematophora silybum Davey, 1979a (48)

Systematophora sp. A of Monteil (1993) (10)

Systematophora spp. (119)

Tanyosphaeridium isocalamum (Deflandre \& Cookson, 1955)

Davey \& Williams, 1969 (43)

Tanyosphaeridium magneticum Davies, 1983 (37)

Tanyosphaeridium sp. DE of Brideaux (1977) (72)

Tehamadinium dodekovae Jan du Chêne et al., 1986b (5)

Tehamadinium evittii (Dodekova, 1969) Jan du Chêne et al., 1986b (56)

Wallodinium krutzschii (Alberti, 1961) Habib, 1972 (24)

Warrenia californica Monteil, 1992a (73)

Wrevittia helicoidea (Eisenack \& Cookson, 1960) Helenes \& Lucas-Clark, 1997 (44)

\section{List of macrofauna}

The list is arranged from bedrock to overlay (in metres the thickness from the beginning of the section, Fig. 3).

Schrambach Formation

114.5 m Mortilletilamellaptychus mortilletinoricus (Trauth)

$120 \mathrm{~m}$ Phylloceras sp.

122 m Mortilletilamellaptychus cf. stanislavi Měchová, Vašíček

\& Houša

$123 \mathrm{~m}$ Erdenella paquieri (Simionescu)

$127 \mathrm{~m}$ in debris Berriasella sp.

$132 \mathrm{~m}$ Bochianites sp., Inoceramus sp.

$138 \mathrm{~m}$ Bochianites $\mathrm{sp}$.

$141 \mathrm{~m}$ in debris Berriasella cf. calisto (d'Orbigny)

$143.5 \mathrm{~m}$ Thorolamellaptychus trauthi (Renz \& Habicht), Bochianites sp., ?Protetragonites quadrisulcatus (d'Orbigny)

$147 \mathrm{~m}$ Bochianites $\mathrm{sp}$., Inoceramus $\mathrm{sp}$.

$169.5 \mathrm{~m}$ Tirnovella alpillensis (Mazenot), Leptoceras brunneri (Ooster), Protancyloceras punicum Arnaud-Saget

$170 \mathrm{~m}$ Neolissoceras grasianum (d'Orbigny), in debris Valanginites bachelardi (Sayn)

177-183 $\mathrm{m}$ in debris Thurmanniceras pertransiens (Sayn), Thurmanniceras otopeta Thieuloy, Protancyloceras punicum Arnould-Saget, Lytoceras sp., Bochianites sp., Inoceramus sp., Mortilletilamellaptychus cf. elegans (Renz), Thorolamellaptychus bermudensis (Renz), rest of Echinoidea

$180 \mathrm{~m}$ Schrambachoceras weidichi sp. nov.

$183 \mathrm{~m}$ Thorolamellaptychus bermudensis (Renz)

190 m Spiticeras cf. correardi Djanélidzé

Rossfeld Formation - lower part

$1.5 \mathrm{~m}$ Bochianites sp.; around, in debris Neocomites neocomiensis (d'Orbigny), Thorolamellaptychus symphysocostatus (Trauth)

$2.5 \mathrm{~m}$ Olcostephanus balestrai (Rodighiero), Valanginites nucleus (Roemer), Bochianites sp. 